PRISCILA DE FRANÇA PINHEIRO

\title{
IMPLANTAÇÃO DA RESPONSABILIDADE SOCIAL EMPRESARIAL NA GESTÃO DE FORNECEDORES DA CONSTRUÇÃO CIVIL - ANÁLISE DO PROGRAMA TEAR
}

\author{
Dissertação apresentada à Escola \\ Politécnica da Universidade de São \\ Paulo para obtenção do título de \\ Mestre em Engenharia
}

São Paulo 
PRISCILA DE FRANÇA PINHEIRO

\title{
IMPLANTAÇÃO DA RESPONSABILIDADE SOCIAL EMPRESARIAL NA GESTÃO DE FORNECEDORES DA CONSTRUÇÃO CIVIL - ANÁLISE DO PROGRAMA TEAR
}

\author{
Dissertação apresentada à Escola \\ Politécnica da Universidade de São \\ Paulo para obtenção do título de \\ Mestre em Engenharia \\ Área de Concentração: \\ Engenharia de Construção Civil e \\ Urbana \\ Orientador: \\ Prof. Dr. Francisco Ferreira Cardoso
}

São Paulo 
Este exemplar foi revisado e alterado em relação à versão original, sob responsabilidade única do autor e com anuência de seu orientador.

São Paulo, 20 de fevereiro de 2009.

Assinatura do autor

Assinatura do orientador

FICHA CATALOGRÁFICA

Pinheiro, Priscila de França

Implantação da responsabilidade social empresarial na gestão de fornecedores da construção civil - análise do Programa Tear / P.F. Pinheiro. -- São Paulo, 2009.

$161 \mathrm{p}$.

Dissertação (Mestrado) - Escola Politécnica da Universidade de São Paulo. Departamento de Engenharia de Construção Civil.

1.Construção civil 2.Responsabilidade social 3.Cadeia de suprimentos I.Universidade de São Paulo. Escola Politécnica. Departamento de Engenharia de Construção Civil II.t. 


\section{AGRADECIMENTOS}

Ao Professor Dr. Francisco Ferreira Cardoso, pela sua orientação no desenvolvimento dessa pesquisa e incentivo em todos os momentos, inclusive nas horas mais difíceis. Chico, obrigada por todo apoio, paciência e dedicação. $O$ mestrado foi uma experiência sem dúvida muito gratificante, especialmente pela sua contribuição. Muito obrigada!

Aos professores da Pós-Graduação em Engenharia de Construção Civil e Urbana, em especial aos da linha de pesquisa Tecnologia e Gestão de Produção Fernando Henrique Sabbatini, Luiz Sérgio Franco, Mercia Maria Semensato Bottura de Barros e Ubiraci Espinelli Lemes de Souza, por compartilharem seus conhecimentos nas disciplinas de mestrado e fazerem parte da minha formação profissional.

Ao Prof. Claudio Tavares pelas contribuições no exame de qualificação.

Ao Prof. Silvio Burrattino Melhado por todo apoio e atenção ao longo do mestrado, pelas aulas, pelos conselhos profissionais, pelas contribuições no exame de qualificação e pela entrevista do estudo exploratório. Obrigada Silvio!

A todos que conheci durante o acompanhamento do Programa Tear, em especial: ao Marcelo Takaoka, pelo entusiasmo e dedicação; a Cristina Fedato, Emi Tanaka e Patrícia Sogayar, por todo apoio e colaboração; a Glaucia Sato (Y. Takaoka), Luciana Tomas e Leôncio Pedrosa (Luciana Tomas Arquitetura), Paula Baillot (Alphageos) e Daniel Ohuma (CTE), pelas entrevistas concedidas para os estudos exploratórios. As contribuições de cada um e as experiências vivenciadas ao longo das reuniões fizeram parte de mais essa conquista da minha vida, tornando-a sem dúvida ainda mais especial. Muito obrigada a todos.

À Dra. Maria Angélica Covelo Silva, que contribuiu com sua experiência e seu conhecimento para uns dos estudos dessa dissertação e que com certeza sempre será pra mim uma grande referência de profissionalismo.

A todos os colegas da Poli que fizeram desses mais de três anos de esforço uma experiência melhor, com os quais pude desenvolver trabalhos e dividir boas 
experiências. Helô, Tati, Vivi, Fábia, Clarice, Cristiano, Eduardo, Flávia, Carlos, Ronaldo, Maurício, Laura, muito obrigada!

À querida Fátima Domingues, que com toda sua simpatia e dedicação, sempre me ajudou com as questões administrativas referentes ao mestrado. E à Maria de Fátima pela ajuda com as referências bibliográficas.

Aos amigos da Lucio Engenharia, especialmente aos engenheiros Luiz Lucio e Manuel Rodriguez, que em diversos momentos compreenderam e permitiram as minhas ausências do trabalho para conclusão do mestrado. Obrigada mesmo!

Ao Prof. Antonio Sergio Itri Conte, do curso de pós-graduação da Fundação Vanzolini, que me incentivou a dar continuidade aos estudos e cursar o mestrado.

Ao Liceu de Artes e Ofícios, em especial as professoras Márcia Cimó e Sandra Casagrande, que me deram a oportunidade de iniciar na vida acadêmica e perceber o quanto é gratificante ensinar! Aos meus ex-alunos do Liceu, que participaram de parte desse período da minha vida e sempre incentivaram minha formação.

Aos meus amigos que sempre apoiaram o meu esforço para concluir essa etapa, peço desculpas pelos momentos que precisei abrir mão da companhia de vocês, mas foi por uma boa causa!

À minha família, tios e primos, que mesmo de longe torceram muito para essa conquista. Em especial aos meus padrinhos Dalva e Rosalino, que são muito importantes na minha vida.

À Tetê, minha segunda mãe, que sentiu muito minha falta nos almoços de domingo, mas que agora voltarei a comparecer sempre! Obrigada por fazer parte da minha vida!

Ao meu pai, Carlos Roberto, que sempre apoiou as minhas iniciativas, e no período do mestrado me deu um grande presente: o Gabriel! Pai, obrigada por tudo que fez por mim até hoje!

Ao meu irmão Fabio. Bi, não tenho nem palavras para descrever o quanto você é importante na minha vida, meu lindo! Sem dúvida, não teria conseguido sem você. 
Seu incentivo diário (principalmente nas horas mais difíceis) e claro, suas broncas, foram fundamentais pra que eu concluísse esse trabalho. Obrigada, de coração.

À minha mãe, Dulce, a pessoa mais importante da minha vida, que desde pequena me incentivou a ir atrás dos meus objetivos, sempre falando que com esforço a gente chega a qualquer lugar. Você é minha referência de garra e força, e ao mesmo tempo meiguice e carinho. Seu apoio e incentivo ao longo desses mais de três anos fizeram a diferença. Obrigada por tudo, não sei se um dia conseguirei retribuir tudo que já fez por mim. 


\section{RESUMO}

A responsabilidade social está sendo discutida nos mais diversos setores e considerada cada vez mais importante na gestão das empresas. As ações de responsabilidade social, que aos poucos vêm se tornando um diferencial em termos de estratégia e competitividade, precisam contribuir para o todo, para a sustentabilidade da sociedade e das pessoas que nela vivem. Devem promover o bom relacionamento e $\mathrm{o}$ atendimento das necessidades de todos os integrantes que compõem um determinado setor e, em particular, das partes diretamente interessadas ao negócio da empresa que as promovem, por meio da criação de ferramentas e mecanismos que garantam o gerenciamento dos conflitos existentes entre eles. O Instituto Ethos de Empresas e Responsabilidade Social, entidade de disseminação dos conceitos de responsabilidade social nos diversos setores da economia brasileira, desenvolveu o Programa Tear, que visa à implementação de ações de responsabilidade social em pequenas e médias empresas fornecedoras envolvidas em diversas cadeias estratégicas de valor, sendo a construção civil uma delas. Essa pesquisa tem por objetivo analisar e avaliar o desenvolvimento desse programa e suas dificuldades de implementação nas empresas fornecedoras do setor da construção civil e busca ainda propor diretrizes de inserção do tema na gestão de empresas incorporadoras e construtoras.

Palavras-chave: responsabilidade social, construção civil, cadeia de suprimentos. 


\section{ABSTRACT}

The social responsibility is being argued in the most diverse sectors and considered each time more important in the management of the companies. The social responsibility actions, that are becoming a differential in strategy terms and competitiveness, need to contribute for all, for the society sustainability and the people who live in it. They must promote the good relationship and the attendance of the necessities of all the integrants that compose one sector and, in particular, of the parts directly affected by the business of the company that promotes them, by the creation of tools and mechanisms that guarantee the management of the existing conflicts between them. The Instituto Ethos de Empresas e Responsabilidade Social, entity of dissemination of the concepts of social responsibility in the diverse sectors of the Brazilian economy, developed the Programa Tear, that aims the implementation of social responsibility actions in small and medium suppliers involved in companies in diverse strategically chains of value, being civil construction one of them. This research aims to analyze and to evaluate the development of this program and its difficulties of implementation in the supplying companies of the civil construction sector and still searches to consider lines of direction to insert the subject in the management of real state developers companies and contractors.

Keywords: social responsibility, civil construction, supply chain. 


\section{SUMÁRIO}

1 INTRODUÇÃO

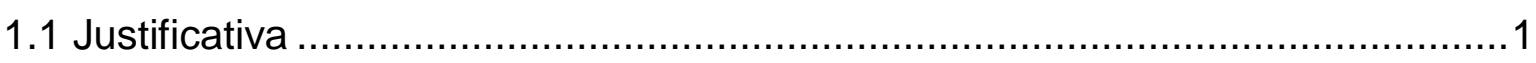

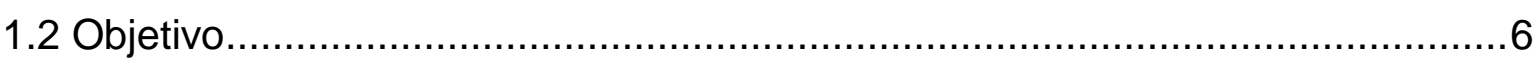

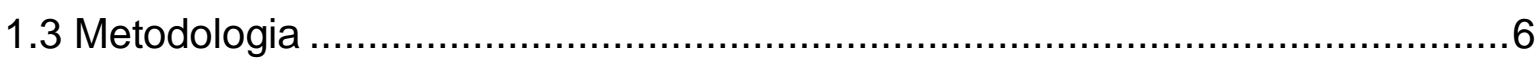

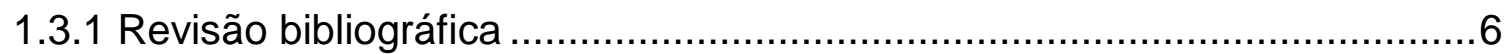

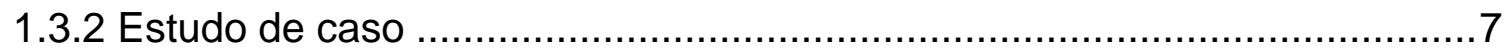

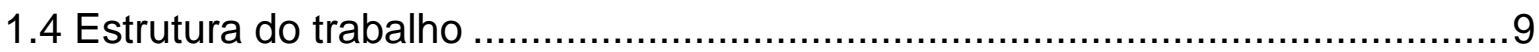

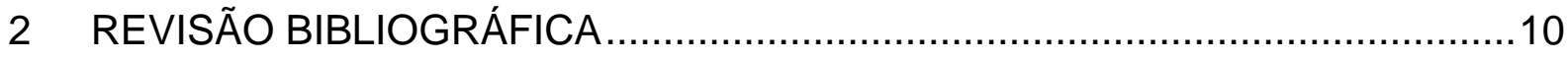

2.1 Responsabilidade social como caminho para o incremento na competitividade

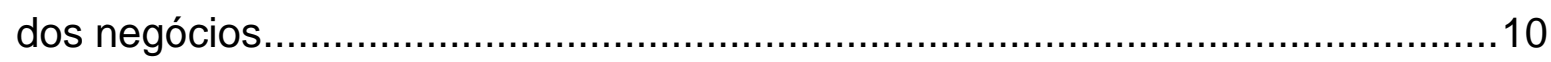

2.1.1 O que é responsabilidade social ...................................................10

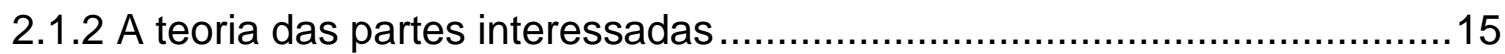

2.1.3 Fatores de competitividade associados à responsabilidade social ..........20

2.1.4 A responsabilidade social na gestão das empresas ................................23

2.1.5 Os referenciais normativos de responsabilidade social...........................25

2.2 Ações de responsabilidade social no setor da construção de edifícios ............43

2.3 Responsabilidade social e cadeia de fornecedores na construção de edifícios

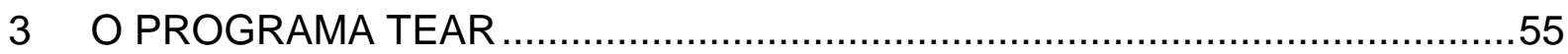

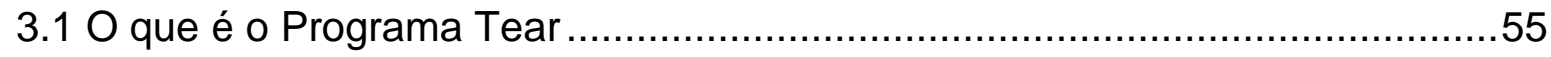

3.2 Vantagens esperadas para as pequenas e médias empresas participantes do

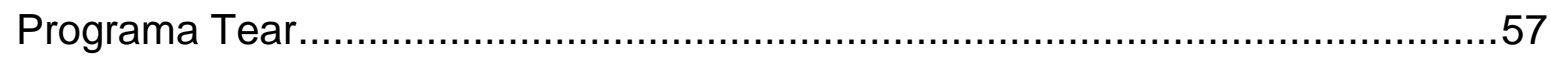

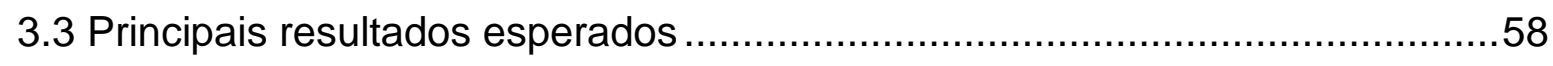

3.4 Metodologia e ferramentas utilizadas no programa ......................................58

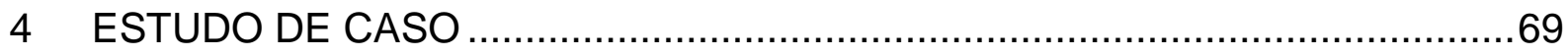

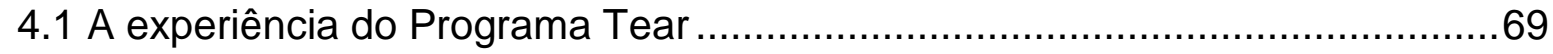

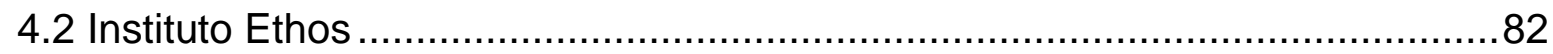

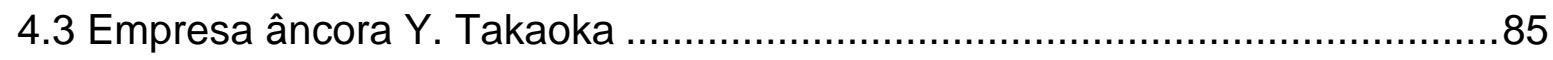

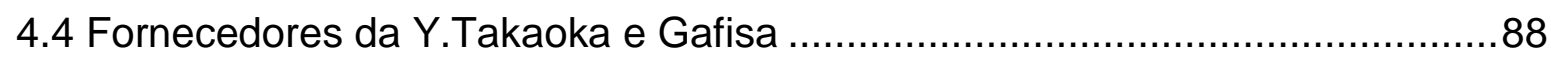

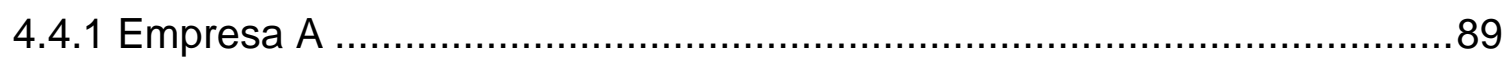

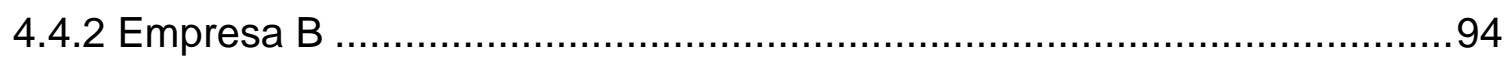

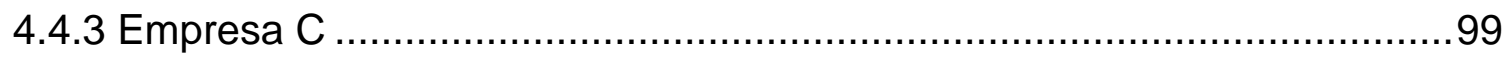


5 ANÁLISE. 104

5.1 Outras experiências de programas em grupos de empresas 104

5.1.1 Programa de Capacitação para Gestão da Qualidade no Desenvolvimento do Projeto na Construção Civil 105

5.1.2 Programa de Desenvolvimento Gerencial de Empresas de Projeto........109

5.2 Análise do Programa Tear e propostas de melhorias 111

5.3 Análise quanto aos referenciais normativos 122

5.4 Dificuldades, impactos e diretrizes para fornecedores 125

5.5 Diretrizes para empresas contratantes 131

5.5.1 Diagnóstico inicial da responsabilidade social 133

5.5.2 Alinhamento estratégico dos departamentos da empresa 133

5.5.3 Escolha dos fornecedores. 133

5.5.4 Perfil dos fornecedores 134

5.5.5 Plano de ação 134

5.5.6 Organização do programa dentro da empresa. 135

5.5.7 Implementação. 136

5.5.8 Melhoria contínua. 136

6 CONCLUSÕES. 137

REFERÊNCIAS BIBLIOGRÁFICAS 141 APÊNDICES. 149 ANEXOS 160 


\section{LISTA DE FIGURAS}

Figura 1 - Revisão dos conceitos corporativos de Desenvolvimento Sustentável, sustentabilidade corporativa, responsabilidade social corporativa e gestão das relações com partes interessadas. (STEURER et al., 2005) ................................17 Figura 2 - Estrutura do referencial AA 1000 (Adaptado de Accountability, 1999)....29 Figura 3 - O modelo do processo do referencial AA 1000 (ACCOUNTABILITY, 1999)

Figura 4 - Modelo de processo do referencial $A A 1000$ (BSD, 2007) .....................32

Figura 5 - Modelo para gestão das partes interessadas (AFNOR, 2003) 35

Figura 6 - Aspectos considerados no modelo proposto para a análise dos agentes da cadeia de suprimentos (JOBIM et. al., 2002)

Figura 7 - Matriz de Kraljic (GUILHERME, 2007)

Figura 8 - Modelo geral empregado na formulação da política de fornecedores (ISATTO, 2006) 52

Figura 9 - Estrutura da Metodologia do Programa Tear (ETHOS, 2007). .73

Figura 10 - Roteiro para plano de ação .79

Figura 11 - Respostas dos participantes em relação aos objetivos do Programa Tear 128 


\section{LISTA DE TABELAS}

Tabela 1 - Ações de responsabilidade social das 100 empresas incorporadoras e construtoras do Ranking ITCnet 2007

Tabela 2 - Principais ações premiadas pelo Prêmio CBIC de Responsabilidade

Social nas edições de 2005, 2006 e 2007 (CBIC, 2008)

Tabela 3 - Resumo das obrigações e deveres da empresa promotora-construtora e do fornecedor (SOUZA et al., 1998)..... 52

Tabela 4 - Empresas e entidades participantes do Programa Tear (ETHOS, 2007) 57

Tabela 5 - Quadro resumo da metodologia do Programa Tear 60

Tabela 6 - Princípios e compromissos assumidos pela cadeia de valor

Y.Takaoka/Gafisa 73

Tabela 7 - Etapas da inserção da responsabilidade social na gestão das empresas .75

Tabela 8 - Modelo para levantamento de informações das partes interessadas......76

Tabela 9 - Atitudes e posicionamento de empresas em relação à RSE ...................77

Tabela 10 - Atendimento aos requisitos da AA 1000 pelo Programa Tear .............123

Tabela 11 - Atendimento aos requisitos da SD 21000 pelo Programa Tear............124

Tabela 12 - Atendimento aos requisitos da NBR 16001 pelo Programa Tear ........125 


\section{INTRODUÇÃO}

\subsection{Justificativa}

Ao longo dos anos, o papel das empresas tem mudado na sociedade. O crescimento populacional impulsionado pelo avanço tecnológico promoveu melhores condições de justiça e desenvolvimento social, porém trouxe consigo o aumento das necessidades e problemas sociais, como a má distribuição de renda, degradação ambiental, violência urbana, etc.

Este ambiente, diante das demandas da população nem sempre atendidas, em parte em função das deficiências do Estado em supri-las, levou a uma situação na qual as empresas deixaram de ser apenas fornecedoras de bens e serviços e passaram também a precisar cumprir papéis que vão além de suas atividades fins. Isso aconteceu até porque a sociedade passou a questionar o papel das empresas em diversas esferas, como nas relações de trabalho, na participação dos trabalhadores nos lucros, entre outras.

Esse novo cenário exige das empresas uma postura diferenciada na gestão de seus negócios, que não abrange somente a sua eficiência técnico-econômica, mas que também leva em conta outros interesses. Considerar os diversos públicos envolvidos em seu negócio para a tomada de decisões é o conceito central da responsabilidade social empresarial.

A responsabilidade social empresarial pode ser definida como um sistema de gestão para gerir os relacionamentos entre o negócio da empresa e as partes interessadas. Segundo o Instituto Ethos de Empresas e Responsabilidade Social ${ }^{1}$, as partes interessadas básicas a serem consideradas na gestão dos negócios são: público interno, meio ambiente, fornecedores, consumidores e clientes, comunidade, governo e sociedade. São as partes interessadas que de uma forma ou de outra sofrem impactos do negócio em questão.

\footnotetext{
${ }^{1} \mathrm{O}$ Instituto Ethos de Empresas e Responsabilidade Social é uma organização não-governamental criada com a missão de mobilizar, sensibilizar e ajudar as empresas a gerir seus negócios de forma socialmente responsável, tornando-as parceiras na construção de uma sociedade sustentável e justa. Disponível em <www.ethos.org.br. $>$.
} 
A responsabilidade social surgiu como conseqüência de diversos movimentos que aconteceram para atender à nova demanda de necessidades da sociedade. Em 1987, a Comissão Mundial de Meio Ambiente e Desenvolvimento da Organização das Nações Unidas (ONU) iniciou a discussão sobre desenvolvimento sustentável, que posteriormente foi aprofundada durante a Eco 92, dando origem à Agenda 21 (UN, 2007), um documento de compromisso das nações signatárias para a solução de problemas sócio-ambientais de âmbito global.

Ainda na década de 80, iniciou-se o movimento da qualidade pela disseminação da ISO 9001, da International Organization for Standardization, com o objetivo de atender as demandas e necessidades dos clientes por meio de um sistema de gestão de empresas estruturado. Em 1996, a publicação da ISO 14001, também da International Organization for Standardization, evidenciou a preocupação com as questões referentes ao meio ambiente. Em 1999, o grupo de trabalho formado por diversos organismos certificadores e a British Standards Institution (BSI) desenvolveu a BSI-OHSAS-18001 Occupational Health and Safety Management Systems, norma para gestão da saúde e segurança do trabalho.

Esses movimentos caracterizam a crescente preocupação da sociedade sob diversos aspectos, tanto sociais quanto ambientais. A integração dessas ações com focos específicos em uma única forma de gestão pode ser encontrada no conceito da responsabilidade social, que considera além dos aspectos econômicos, os aspectos sociais e ambientais na gestão dos negócios.

O movimento atual da responsabilidade social tem alguns aspectos em comum quando comparado ao movimento da qualidade da década de 90 , pois, de forma similar, empresas pioneiras vêm investindo na implementação da responsabilidade social em sua gestão. A busca das empresas para adotar os conceitos da responsabilidade social em sua gestão justifica a criação das metodologias e normas que vêm sendo publicadas para orientar esse processo. A International Organization for Standardization está elaborando a ISO 26000, mas já existem também as normas AA 1000 (ACCOUNTABILITY, 2003), SA 8000 (SAI, 2001) e a NBR 16001 (ABNT, 2004), e outras metodologias propostas por entidades de classe e organizações não governamentais, como os Indicadores Ethos de Responsabilidade Social (ETHOS, 
2008), que são importantes ferramentas para um bom resultado na implementação do conceito.

Uma questão importante a ser levantada é o que leva as empresas a adotarem a responsabilidade social em seus negócios e por que o investimento vem crescendo nessa área. A responsabilidade social, diferente do que se pode imaginar, não é uma restrição à lucratividade dos negócios. Na verdade, cria valores para a empresa em termos de vantagem competitiva (BLAKE, 2007).

O incremento da competitividade associada ao investimento em responsabilidade social pode ser visto também na Bovespa - Bolsa de Valores de São Paulo, onde já existe um índice de ações que é referencial para os investimentos socialmente responsáveis, o Índice de Sustentabilidade Empresarial (ISE). Segundo a Bovespa, o ISE "tem por objetivo refletir o retorno de uma carteira composta por ações de empresas com reconhecido comprometimento com a responsabilidade social e a sustentabilidade empresarial, e também atuar como promotor das boas práticas no meio empresarial brasileiro" (BOVESPA, 2007). Essa prática se repete em outras bolsas do mundo, como a norte-americana Dow Jones, que possui o Dow Jones Sustainability Index.

Embora esse exemplo seja importante, o mercado brasileiro ainda encontra algumas barreiras para adoção dos conceitos de responsabilidade social em função do desconhecimento. Para auxiliar na disseminação desses conceitos, em 1998 foi fundado o Instituto Ethos de Empresas e Responsabilidade Social, que é uma organização não governamental sem fins lucrativos que busca disseminar como incorporar responsabilidade social aos negócios. O Instituto Ethos se mantém por meio da contribuição financeira de seus associados, que hoje já são mais de 1.200 , e também realiza parceiras com instituições financeiras para realização de programas específicos (ETHOS, 2007). A iniciativa do Instituto Brasileiro de Análises Sociais e Econômicas - IBASE, ao lançar o selo Balanço Social Ibase/Betinho em 1998 (IBASE, 2008), também contribuiu para disseminar a responsabilidade social no país.

Para adotar o conceito da responsabilidade social na gestão dos negócios, não basta apenas destinar uma verba para assistencialismo social. Outras partes 
afetadas pelas atividades do negócio devem ser consideradas. Cada uma dessas partes interessadas precisa ser avaliada, para que suas demandas e necessidades sejam atendidas de alguma forma, gerando equilíbrio na gestão, pois a reputação das empresas é avaliada de forma global. Não é suficiente investir em replantio de árvores quando os funcionários da empresa trabalham em condições inadequadas de saúde e segurança, desrespeitando o marco legal. Ou mesmo investir em direitos humanos em sua planta de produção e adquirir matéria-prima de um fornecedor que utiliza mão-de-obra informal.

Portanto, para que a empresa atue de forma socialmente responsável, toda sua cadeia de suprimentos deve estar comprometida. As empresas não competem mais de forma isolada, dependem também de seus fornecedores para atender às expectativas de seu cliente final. Estes assumem assim, dentre as partes interessadas, um papel de maior relevância.

No setor da construção civil, empresas incorporadoras e também as construtoras formam uma grande cadeia para viabilizar seus negócios e, de certa forma, são o centro dos negócios do mercado imobiliário, pois são elas que demandam o fornecimento de materiais, projetos, mão-de-obra, equipamentos, etc. Pelo porte e capacidade de mobilização de recursos, as incorporadoras e construtoras têm um papel importante no desenvolvimento de seus fornecedores de menor porte, tanto os de materiais e componentes como dos de serviços, especialmente os de projeto e execução, já que na sua maioria são empresas de pequeno e médio portes, que não dispõem de recursos suficientes para investimento e para disponibilizar parte do tempo de seus dirigentes e colaboradores para as tarefas necessárias à implementação de práticas de responsabilidade social.

Portanto, o papel de empresa focal da cadeia de suprimentos, aliado ao maior porte em relação à maioria dos fornecedores, exceção normalmente feita a certas indústrias de materiais e componentes, fazem com que as empresas incorporadoras e construtoras tenham que assumir um papel de liderança em prol de uma cadeia socialmente mais responsável no setor. Isso se reflete inclusive na questão do desenvolvimento dos projetos dos empreendimentos. Todo um trabalho focado na atuação socialmente responsável junto às partes interessadas do negócio pode ser 
comprometido ao não serem consideradas diretrizes importantes para que os empreendimentos sejam mais sustentáveis.

Independentemente de a empresa incorporadora ou construtora já possuir ou não em sua gestão um processo de mudança de cultura empresarial baseado nos conceitos de responsabilidade social, tanto por meio do comprometimento da alta direção como também da criação valores para a organização, ao engajar-se num processo como este é assim importante que ela também invista em sua cadeia de fornecedores, para convergir os esforços em busca de melhores resultados em parceria.

A cadeia de fornecedores possui grande impacto na responsabilidade social das incorporadoras e construtoras quando consideramos os efeitos negativos decorrentes de um projeto mal desenvolvido, da extração ilegal de recursos naturais ou mesmo das condições inadequadas de trabalho da mão-de-obra dos empreiteiros.

É neste contexto que se justifica o objetivo do Programa Tear, desenvolvido pelo Instituto Ethos com o apoio do Banco Interamericano de Desenvolvimento (BID). O Programa pretende atingir as pequenas e médias empresas de diversos setores produtivos da economia brasileira com o auxílio de empresas "âncoras", que possuem ascensão sobre as demais de suas cadeias de suprimentos, promovendo a capacitação das mesmas em responsabilidade social. A idéia é fazer com que essas pequenas e médias empresas aprendam a incluir em sua gestão os conceitos e ferramentas de responsabilidade social e, dessa maneira, contribuam para 0 desenvolvimento do setor de forma mais abrangente.

No caso do setor da construção civil, foram definidos dois grupos de trabalho: um para o setor da construção pesada e outro para o de edificações. A Construções e Comércio Camargo Corrêa S.A. foi escolhida como a âncora da cadeia de construção pesada e a Y.Takaoka Empreendimentos S.A., juntamente com a Gafisa S.A., foram escolhidas para serem as âncoras das cadeias de suprimentos do setor de edificações - incorporação e construção. A experiência está atualmente em curso e há interesse em acompanhá-la, avaliá-la e dela tirarem-se ensinamentos. 


\subsection{Objetivo}

Esta dissertação tem como objetivos:

1. Analisar e avaliar a implementação do Programa Tear no setor de incorporação da construção civil;

2. Analisar as dificuldades e impactos trazidos pela participação das empresas fornecedoras do setor da construção civil no Programa Tear;

3. Propor diretrizes de inserção do tema da responsabilidade social na gestão de empresas incorporadoras e construtoras em relação a seus fornecedores.

\subsection{Metodologia}

A metodologia de pesquisa estabelecida para cumprir seus objetivos se resume às etapas apresentadas a seguir, tendo sido empregadas duas abordagens complementares, revisão bibliográfica e estudo de caso, sendo que nesta diferentes estratégias foram adotadas.

\subsubsection{Revisão bibliográfica}

A revisão bibliográfica trouxe subsídios para o embasamento teórico da dissertação sob os seguintes aspectos:

- responsabilidade social empresarial como caminho para o incremento na competitividade dos negócios;

- ações de responsabilidade social no setor da construção civil (ações bem sucedidas por parte das empresas incorporadoras e construtoras);

- responsabilidade social e cadeia de fornecedores no setor da construção civil.

Foram utilizadas como fontes de pesquisa livros, dissertações e teses, além de normas nacionais e internacionais para gestão da responsabilidade social, bem como trabalhos relatados em anais e em revistas científicas. 


\subsubsection{Estudo de caso}

Para melhor entendimento do Programa Tear e de seus impactos e melhor identificar as dificuldades de sua implementação, os estudos de caso realizados foram os seguintes:

- Estudo de caso do Programa Tear: O Programa Tear, descrito no capítulo 3, tem como parte de sua metodologia de implementação a realização de reuniões mensais ao longo de dois anos. O Programa Tear teve início em setembro de 2006 e, para a elaboração dessa dissertação, as reuniões mensais foram acompanhadas pela pesquisadora desde janeiro de 2007 até outubro de 2008 (mês de encerramento do programa). Esse estudo de caso foi uma importante ferramenta para vivenciar a experiência do programa e para um melhor entendimento de sua dinâmica. Pretendeu-se dessa forma documentar a experiência do programa, apresentar e analisar criticamente a metodologia por ele adotada, incluindo as dificuldades de implementação pelos fornecedores participantes. Cabe salientar ainda que a pesquisadora acompanhou as reuniões como observadora da dinâmica, e conseqüentemente as constatações e críticas apresentadas advém dessa situação. Para complemento das informações referentes ao Programa Tear, foi elaborado um questionário que foi respondido por um representante do Instituto Ethos responsável pelo programa por meio de entrevista.

- Estudo da empresa Y.Takaoka no âmbito do Programa Tear: um dos papéis das empresas "âncora" definidos pelo Programa Tear é nortear as pequenas e médias empresas participantes durante todo o processo previsto na metodologia. Uma das "âncoras" foi selecionada (Y.Takaoka) e estudada para: identificar as práticas de responsabilidade social existentes, tanto antes do programa quanto também as adotadas ao longo do mesmo; eleger fatores e expectativas que levaram a empresa a participar do programa; levantar suas experiências quanto ao relacionamento com fornecedores e; listar fontes de ganhos após a capacitação de seus fornecedores por meio do programa. Esse estudo de caso foi importante para um melhor entendimento do papel da empresa "âncora" dentro do programa e o quanto ela contribuiu para o processo de capacitação das empresas participantes. A escolha da Y.Takaoka como estudo de caso entre 
as duas "âncoras" foi baseada em três critérios: o comprometimento do proprietário da empresa com o programa, justificado pela sua presença na maioria dos encontros; o relacionamento que o proprietário da empresa já possui com a Escola Politécnica da USP, o que favorece o apoio à pesquisa; e também a centralização das informações referentes ao Programa Tear em um grupo pequeno de pessoas, o que reflete numa maior coerência e confiabilidade das informações. A identificação das fontes de ganhos, assim como das magnitudes obtidas, foi obtida por entrevista com representante da Y.Takaoka.

- Estudo de três pequenas / médias empresas participantes do Programa Tear, fornecedoras da Y.Takaoka, que foram convidadas a participar da iniciativa: Essas empresas foram estudadas para identificar fatores que as levaram a participarem do programa; listar suas expectativas quanto aos resultados do programa; levantar suas experiências quanto ao seu relacionamento com clientes; relatar a experiência (dificuldades) das mesmas quanto à implementação das etapas previstas na metodologia do programa e; identificar fontes e incrementos nos resultados dos negócios. A escolha dos fornecedores foi feita juntamente com representantes do Instituto Ethos, para identificação de empresas que demonstraram comprometimento com o programa, por meio do cumprimento de prazos, participação das tarefas, contribuição com o grupo de trabalho, entre outros. Outro critério de escolha foi o maior vínculo da atividade da empresa fornecedora com o setor da construção civil. A identificação das fontes de ganhos, assim como das magnitudes obtidas, foi obtida por entrevista com representantes das empresas escolhidas.

- Estudos exploratórios de outros movimentos setoriais: optou-se pelo estudo, por meio de entrevistas com seus idealizadores, de dois diferentes movimentos setoriais para o entendimento de outras dinâmicas de capacitação de empresas, para compará-las ao Programa Tear quanto à sua forma de condução e impactos nas empresas. 


\subsection{Estrutura do trabalho}

Essa dissertação está dividida em seis capítulos, descritos a seguir.

O Capítulo 1 apresenta a justificativa da pesquisa, seus objetivos e a metodologia adotada para sua elaboração.

O Capítulo 2 faz a revisão bibliográfica acerca do tema proposto, apresentando os conceitos de responsabilidade social empresarial, sua evolução ao logo do tempo, com ênfase no incremento que proporciona na competitividade dos negócios, e como o tema está inserido no setor da construção civil. Explora-se, ainda, a questão do relacionamento das empresas com sua cadeia de fornecedores e como a responsabilidade social pode contribuir nesse sentido.

O Capítulo 3 apresenta o Programa Tear, sua concepção, estrutura, ferramentas utilizadas e metodologia.

O Capítulo 4 apresenta o estudo de caso do Programa Tear, os estudos realizados com a empresa âncora do programa selecionada e as três empresas fornecedoras participantes, e os estudos sobre as experiências setoriais em grupos de empresas.

O Capítulo 5 apresenta as análises feitas com base no conhecimento obtido na revisão bibliográfica, no acompanhamento da dinâmica de reuniões do Programa Tear e nos estudos realizados, culminando com as propostas de diretrizes para inserção da responsabilidade social empresarial com foco nas ações com fornecedores em empresas incorporadoras e construtoras.

O Capítulo 6 apresenta as conclusões da pesquisa realizada e aponta caminhos para o desenvolvimento e continuidade da pesquisa no tema. 


\section{REVISÃO BIBLIOGRÁFICA}

\subsection{Responsabilidade social como caminho para 0 incremento na competitividade dos negócios}

\subsubsection{O que é responsabilidade social}

A responsabilidade social, tema que vem ganhando importância ao longo dos anos, é bastante ampla e gera diferentes interpretações. Pode representar idéias como o simples cumprimentos de leis pelas empresas, a realização de ações sociais por meio de doações e contribuições ou, ainda, a atuação ética e responsável nos negócios.

A Comissão das Comunidades Européias (2001), em sua publicação "Livro VerdePromover um quadro europeu para a responsabilidade social das empresas", define a responsabilidade social como "um conceito segundo o qual as empresas decidem, numa base voluntária, contribuir para uma sociedade mais justa e um ambiente mais limpo, (...) comportamento que as empresas adotam voluntariamente e para além das prescrições legais, porque consideram ser esse o seu interesse de longo prazo".

Ashley et al. (2002) definem responsabilidade social como: "O compromisso que uma organização deve ter para com a sociedade, expresso por meio de atos e atitudes que a afetem positivamente, de modo amplo, ou a alguma comunidade, de modo específico, agindo proativamente e coerentemente no que tange a seu papel específico na sociedade e a sua prestação de contas para com ela".

O World Business Council for Sustainable Development - Conselho Empresarial Mundial para o Desenvolvimento Sustentável (1999) define responsabilidade social como "o comprometimento das empresas em contribuir para o desenvolvimento econômico sustentável, trabalhando com seus empregados e suas famílias, a comunidade local e a sociedade como um todo para melhoria da qualidade de vida".

O guia SD 21000 Guide da Association Française de Normalisation (AFNOR, 2003) define responsabilidade social como "a integração voluntária das preocupações ecológicas e sociais das empresas dentro de suas atividades comerciais e sua 
relação com suas partes interessadas, indo além das obrigações legais e investindo mais no capital humano e no meio ambiente".

A norma NBR 16000 (ABNT, 2004), em suas definições, cita a responsabilidade social como a "relação ética e transparente da organização com todas as suas partes interessadas, visando o desenvolvimento sustentável".

O Instituto Ethos de Empresas e Responsabilidade Social define responsabilidade social como: "A forma de gestão que se define pela relação ética e transparente da empresa com todos os públicos com os quais ela se relaciona e pelo estabelecimento de metas empresariais compatíveis com o desenvolvimento sustentável da sociedade, preservando recursos ambientais e culturais para as gerações futuras, respeitando a diversidade e promovendo a redução das desigualdades sociais" (ETHOS, 2007).

As visões dessas diversas fontes e de outras que também tratam do tema são divergentes em relação ao quanto são evidenciados os aspectos relacionados à responsabilidade social, sendo eles econômicos, sociais e ambientais. A ética e o desenvolvimento sustentável estão presentes nas definições dando embasamento a elas, porém com um escopo ainda subjetivo. A Comissão das Comunidades Européias (2001) considera a questão das ações que vão além das prescrições legais; o World Business Council for Sustainable Development (2002) enaltece a questão da qualidade de vida. O guia da AFNOR (2003) fala sobre as preocupações ecológicas e sociais associadas à gestão das empresas. Ashley et al. (2002) destacam a importância da atuação junto à comunidade. A norma da ABNT (2004) resume o tema ao relacionamento ético baseado no desenvolvimento sustentável. Já o Instituto Ethos (2007) deixa mais evidente o papel das empresas em relação aos diversos públicos afetados pela atividade de seu negócio.

As interpretações do tema são diversas e em alguns casos seguem a tendência do ambiente em estudo. A percepção da responsabilidade social pode também ser diferente em países desenvolvidos e em desenvolvimento, principalmente em função dos diferentes papéis das empresas em cada um desses cenários. Além da abrangência e eficiência das ações do Estado em cada uma das situações, a natureza de consumo também é um fator de relevância nas ações de 
responsabilidade social (FELDBERG, 1974). Porém, Furtado (2003) sugere ainda uma maior ênfase à questão ambiental, expandindo o foco da responsabilidade social para responsabilidade socioambiental, definida pelo autor como "o dever ou obrigação da organização para responder - perante todas as partes interessadas pelas conseqüências ou impactos sociais causados por seus produtos, serviços e atividades introduzidos no ambiente público".

Percebe-se, portanto, que os termos utilizados nas diversas definições de responsabilidade social podem ser os mesmos, porém, em alguns casos, são interpretados de maneiras diferentes em função do cenário no qual se aplicam. Garriga e Melé (2004) salientam que diversos autores utilizam as mesmas terminologias para diferentes definições da responsabilidade social, e classificam essas definições em quatro grupos:

1. O primeiro grupo, no qual é considerado somente o aspecto econômico e de geração de lucros entre empresa e sociedade, e as ações sociais só são realizadas com a perspectiva de obtenção de lucro.

2. O segundo, onde o poder social das empresas é enfatizado, especialmente na relação com a sociedade e sua responsabilidade no cenário político.

3. O terceiro, em que a integração com as demandas da sociedade é entendida como um fator de longevidade e crescimento das empresas.

4. O quarto, onde a relação entre as empresas e a sociedade precisa ser sustentada por valores éticos.

Esses grupos não enfatizam a questão ambiental, que fica subentendida como uma das partes interessadas impactadas pelas atividades das empresas. Nessa dissertação, é considerada a visão na qual o meio ambiente é uma das partes interessadas.

É também importante se considerar a dimensão temporal. Assim, as definições de responsabilidade social são resultado da evolução do conceito do tema, que nos últimos 50 anos teve muitas contribuições de diversos pesquisadores. 
O início da discussão do tema, segundo Carroll (1999), consolidou-se com a publicação do livro de Howard Bowen (1953), Social Responsibilities of the Businessman, que discute o papel dos empresários e as responsabilidades que devem assumir. Bowen (1953) definiu a responsabilidade social como "a obrigação do empresário de adotar práticas, tomar decisões e acompanhar linhas de ação desejáveis segundo os objetivos e valores da sociedade". Dessa forma, o conceito da responsabilidade social teve seu marco inicial e foi ao longo dos anos sendo estudado por outros pesquisadores.

Antes disso, em 1920 foi criada a Liga das Nações para promoção da paz e segurança mundiais no pós-guerra e, em 1948, a Organização das Nações Unidas (ONU) publicou a Declaração Universal dos Direitos Humanos, após a Segunda Guerra Mundial (ETHOS, 2004), já sinalizando a preocupação social do mundo.

$\mathrm{Na}$ década de 60 , o desafio foi deixar mais claro e evidente o significado da responsabilidade social. Davis $(1960)^{2}$, citado por Carroll (1999) como um dos primeiros autores da época, trouxe a idéia de que a responsabilidade social deve ser tratada no contexto gerencial e deve ultrapassar os interesses técnicos e econômicos da empresa, podendo-lhe trazer retornos financeiros em longo prazo. Ou seja, o tema não deve tratar o assunto apenas de forma pontual, e sim de uma forma mais ampla. McGuire (1963) ${ }^{3}$, igualmente citado por Carroll (1999), complementa afirmando ainda que as empresas não possuem só compromissos econômicos, mas também com a comunidade, com as questões políticas, com a educação e felicidade dos empregados.

Carroll (1999) cita Johnson $(1971)^{4}$ pela sua importante contribuição para o tema na década de 70 , incluindo as partes interessadas ao conceito de responsabilidade social. Em 1977, a França criou a lei do balanço social, contemplando os direitos humanos no ambiente de trabalho (ETHOS, 2004), mais um sinal da mudança dos valores da sociedade.

\footnotetext{
${ }^{2}$ DAVID, K. Can Business afford to ignore social responsibilities? California Management Review, n.2, p. 70-76, 1960).

${ }^{3}$ McGUIRE, J. W. Business and society. New York: McGraw-Hill, 1963.

4 JOHNSON, H. L. Business in contemporary society: Framework and issues. Belmont, CA. Wadsworth, 1971.
} 
Ao contrário das décadas anteriores, os anos 80 foram marcados pela ênfase dada à pesquisa e a temas alternativos relacionados à responsabilidade social. Até então a questão ambiental estava pouco associada ao tema, porém o desastre de Chernobyl coloca em questão os perigos da energia nuclear e as questões ambientais (ETHOS, 2004).

Seja devido ao ambiente ao qual ela se aplica, seja em função do seu grau de compreensão no tempo, fato é que, segundo Vieira (2007), o termo responsabilidade social ainda não consegue definir claramente como uma empresa pode atender aos diversos interesses públicos sem perder suas características de unidade econômica. Nessa mesma linha, Queiroz (2000) afirma: "Há ainda, entretanto, pouco consenso sobre a definição deste conceito. É necessário um esforço acadêmico no sentido de melhor compreender a experiência brasileira e encontrar formas teóricas adequadas para a nossa realidade. Um desafio nessa área é a caracterização e a avaliação das ações de responsabilidade social das empresas". Ashley et al. (2002) também concordam que o conceito "[...] ainda não está suficientemente consolidado e que, portanto, pode ser considerado em construção".

De certa forma, pode-se considerar que as diferentes visões sobre o tema podem sinalizar uma falta de consenso. Porém, analisando os termos utilizados na construção das definições aqui apresentadas, é possível identificar a convergência de idéias para expressar o significado da responsabilidade social empresarial, podendo-se elencar alguns pontos em comum:

- ética na gestão dos negócios;

- contribuição para uma sociedade mais justa e melhoria da qualidade de vida;

- realização de ações proativas que ultrapassem as obrigações legais;

- atuação junto à comunidade e empregados;

- prestação de contas das ações de responsabilidade social;

- contribuição para o desenvolvimento sustentável;

- inclusão das partes interessadas na gestão do negócio;

- preservação de recursos ambientais e culturais; 
- respeito à diversidade e promoção da redução de desigualdades sociais.

O conceito de responsabilidade social empresarial adotado nessa dissertação incorpora todos estes pontos.

\subsubsection{A teoria das partes interessadas}

Para agir de forma socialmente responsável, as empresas precisam descobrir o seu foco, direcionando seus investimentos de forma a obterem retornos satisfatórios, podendo então se beneficiar da adoção das práticas de responsabilidade social nos negócios.

A teoria das partes interessadas (ou teoria dos stakeholders) tem o objetivo de delinear os grupos específicos ou as pessoas que a empresa deve considerar na orientação de sua responsabilidade e atuação social (BORGER, 2001). As discussões anteriormente apresentadas mostraram a importância do tema.

A empresa que deseja agir de maneira socialmente responsável precisa passar por um processo de "mapeamento" de suas partes interessadas, ou seja, identificar quem são os indivíduos, grupos, organizações e instituições que possuem alguma relação com o seu negócio e que de alguma forma afetam ou são afetados pelas suas atividades.

Mesmo sem o interesse da empresa em investir em responsabilidade social, Fedato (2005) sinaliza que as interfaces da atuação social com o negócio existem independente de serem intencionalmente planejadas, devido à imersão das empresas numa "teia de relações" em seu entorno, onde seus limites atuação e de responsabilidades são cada vez menos claros. Ou seja, de qualquer forma a empresa vai sempre manter o relacionamento com suas partes interessadas; o que pode ser modificado é a forma como a empresa vai conduzir essas relações.

Ashley et al. (2002) observam que o conhecimento da rede de relacionamentos da empresa, ou seja, de suas partes interessadas, é fundamental para a sustentação de uma orientação estratégica para a responsabilidade social nos negócios. 
Além da importância de considerar os interesses dos diversos públicos relacionados à atividade de uma empresa, Neville e Menguc (2006) ressaltam a importância da identificação e consideração das partes interessadas com base em seu poder, legitimidade e urgência em suas reivindicações, pois as demandas das partes interessadas podem pressionar a empresa em diferentes direções. As relações entre as diversas partes interessadas e a empresa são diferentes, assim como a influência destes no comportamento das empresas (BORGER, 2001).

Para Borger (2001), a gestão das partes interessadas é complexa e envolve o reconhecimento de seus valores, direitos e interesses e a busca de um equilíbrio entre estes para que as decisões sejam tomadas dentro de um contexto mais amplo e num horizonte de longo prazo.

Porém, além de levar em conta o que cada parte interessada espera dos negócios de uma empresa, Neville e Menguc (2006) sugerem ainda a consideração dos possíveis efeitos quando essas expectativas são multiplicadas por uma "complexa rede" de partes interessadas. Os autores sugerem que o primeiro passo para considerar os efeitos de várias partes interessadas é considerar a congruência de interesses entre eles. O segundo passo é considerar a influência das partes interessadas em rede.

A gestão das partes interessadas, segundo Steurer et al. (2005), pode ser realizada segundo o modelo proposto na figura 1, onde as partes interessadas são classificadas nas dimensões econômica, social e ambiental, e cada um deles está mais ou menos próximo das decisões estratégicas da empresa conforme seu impacto.

Miles et al. (2006) acreditam que discussões estratégicas irão minimizar futuros conflitos entre a empresa e suas partes interessadas. Modelos tradicionais de decisões estratégicas, como o Balanced Scorecard, que consideram o desempenho organizacional sob as perspectivas financeira, do cliente, os processos internos e de aprendizado e crescimento (HERNANDES et al., 2000), não são tão abrangentes quanto os princípios da responsabilidade social, pois possuem um escopo menor de atuação em relação aos os interesses de todas as partes interessadas envolvidas na gestão das empresas, deixando de lado questões como o meio ambiente e a 
sociedade. Os empresários precisam considerar as expectativas das partes interessadas na estratégia de desenvolvimento de suas ações, adotando uma postura "de fora para dentro" (MILES et al., 2006), gerenciando as diversas demandas para melhorar sua atuação como organização.

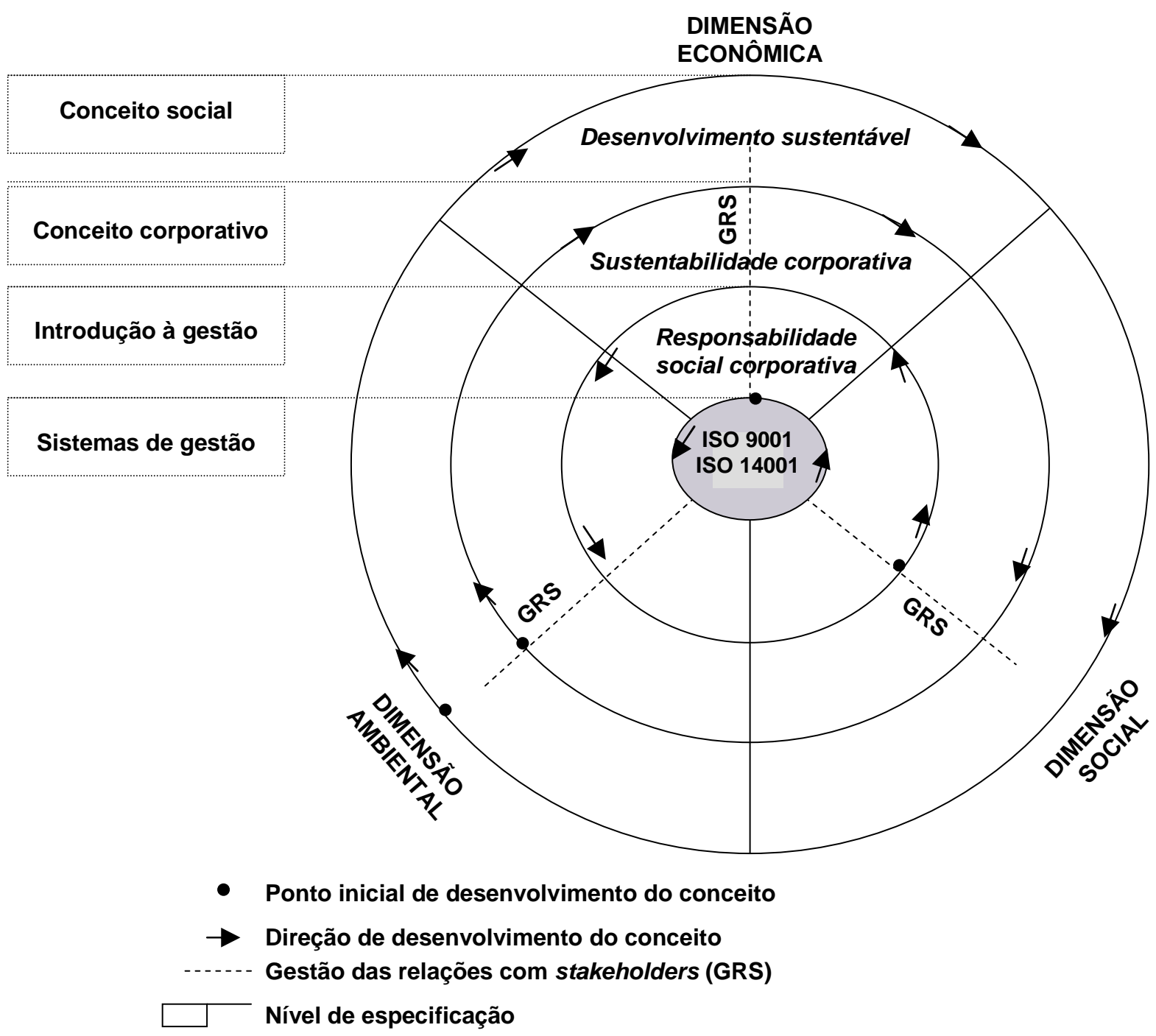

Figura 1 - Revisão dos conceitos corporativos de Desenvolvimento Sustentável, sustentabilidade corporativa, responsabilidade social corporativa e gestão das relações com partes interessadas. (STEURER et al., 2005)

Nasi et al. (1997) apontam em sua análise sobre teorias de gestão corporativa que a teoria das partes interessadas, comparada a outras, como a Análise do Ciclo de Vida 
e a Teoria da Legitimidade $^{5}$, foi a melhor avaliada, pois com sua adoção as empresas conseguem identificar e responder às demandas das partes interessadas, inclusive os mais poderosos. O grau de poder da parte interessada está relacionado à sua influência nas operações da empresa, e como as diferentes partes interessadas podem ganhar ou perder forças em função do cenário em questão, as ações das empresas junto a eles devem ser dinâmicas, mudando conforme a necessidade. Novas determinações legais, manifestações por parte da sociedade, atividades de grande impacto ao meio ambiente e greves são exemplos de diferentes pressões externas que podem acontecer e precisam ser priorizadas e resolvidas a tempo de não causarem grandes impactos à empresa, já que empresas que falham ao responder a uma poderosa parte interessada podem ter problemas.

Na experiência de Freeman e Liedtka (1997), existem quarto tipos de stakeholders (ou partes interessadas):

1. Swing stakeholders (ou partes interessadas oscilantes): são aquelas que podem impactar os objetivos da empresa de forma positiva ou negativa se mudarem de comportamento. Como exemplo pode ser citado o governo na gestão das leis.

2. Defend stakeholders (ou partes interessadas defensoras): são aquelas que já ajudam a empresa e seu suporte é crucial na garantia de desempenho da mesma, e como exemplo podem ser citados os empregados em uma situação onde já existe uma relação boa e produtiva.

3. Opportunity stakeholders (ou partes interessadas de oportunidade): são aquelas que se dispõem a realizar pequenas ações para ajudar a empresa, com uma indicação a ser dada na ocasião da estratégia da empresa não atingir seu objetivo.

4. Monitor stakeholders (ou partes interessadas a monitorar): são aquelas que podem ser importantes, mas como dispõem de poucas opções para

\footnotetext{
${ }^{5}$ A Teoria da Legitimidade é uma avaliação feita pela sociedade de uma empresa e suas atividades, podendo sua avaliação ser altamente legitima ou altamente ilegítima. É baseada em normas culturais de comportamento corporativo. A sociedade julga a legitimidade de uma empresa com base em sua imagem. Portanto, não é uma característica da empresa, e sim uma avaliação da adequação entre percepções do comportamento da empresas versus as expectativas da sociedade (NASI et al., 1997).
} 
mudarem de comportamento, há pouca margem de manobra, apresentando pouca flexibilidade.

Os autores ainda afirmam que, prestando atenção aos perfis das partes interessadas, os empresários podem realizar análises para entender onde existem oportunidades para agregar valor às suas ações, onde há maiores oportunidades para cooperação e onde há necessidade de sustentar valor anteriormente criado.

As partes interessadas podem, ainda, estar organizadas em seis grupos: público interno, meio ambiente, fornecedores, clientes, comunidade e governo e sociedade (ETHOS, 2007).

$\mathrm{Na}$ experiência de Zutshi e Sohal (2004), que focaliza a questão ambiental, foi constatado que o público interno (os empregados) tem um importante papel na adoção de um sistema de gestão ambiental, especialmente nos estágios de implementação. Para isso, eles devem ser treinados de forma a se capacitarem nas questões ambientais e no entendimento do sistema de gestão de maneira global. A participação dos fornecedores no processo de gestão ambiental é mais restrita, pois em alguns casos a empresa também precisa investir na sua capacitação, especialmente dos menores, para que se atinjam os objetivos esperados no sistema de gestão (ZUTSHI; SOHAL, 2004).

Segundo Neville e Menguc (2006), a influência do governo nas empresas é a mais notável, seguida pelos consumidores e empregados (público interno), pois o governo tem o poder de criar leis e regulamentações, e também punir aqueles que não as cumprem. As decisões tomadas pelo governo podem influenciar a decisão pela alocação de recursos das organizações, pois esses recursos podem ser necessários para suprir determinações legais.

Diante das diferentes demandas e influências das diversas partes interessadas envolvidas em um determinado negócio, cabe às empresas identificar quais ações são prioritárias, avaliando inclusive as relações existentes entre elas.

Esta dissertação volta-se a uma dessas partes interessadas, os fornecedores. 


\subsubsection{Fatores de competitividade associados à responsabilidade social}

Os resultados alcançados pela adoção de práticas de responsabilidade social na gestão das empresas nem sempre são diretamente mensuráveis e, segundo Fedato (2005), muitas vezes são intangíveis, tanto do ponto de vista do efetivo benefício social gerado como do retorno para a empresa.

López et al. (2007) afirmam que ações de responsabilidade social, alinhadas às decisões estratégicas da empresa, certamente trazem conseqüências positivas e repercussões qualitativas, que nem sempre são quantificáveis quanto ao seu impacto econômico e financeiro.

Ao comparar dois grupo de empresas, um que adotou práticas de sustentabilidade para atender aos requisitos do Índice de Sustentabilidade da Dow Jones e outro grupo que não adotou prática alguma, López et al. (2007) concluíram que as diferenças de desempenho entre os grupos aconteceram em períodos específicos e não foram constantes, o que indica que a adoção de práticas de sustentabilidade não teve repercussões positivas nos indicadores. O investimento da empresa em ações sustentáveis pode colocá-la em uma desvantagem econômica em relação às demais, menos responsáveis, ao menos num curto período de tempo, o que pode influenciar a decisão de empresas que ainda não atuam de forma sustentável a nunca fazê-lo.

Esse é um cenário que coloca em questão a adoção de práticas de responsabilidade social. Kitahara (2007) afirma que a esperança preponderante de impacto positivo ou neutro da responsabilidade social sobre o desempenho financeiro se deve a que a maioria dos estudos suporta a idéia de que bom desempenho social não leva a um desempenho financeiro ruim, isso é, mesmo que não exista uma relação direta significativa entre a responsabilidade social e o desempenho financeiro das empresas, as investigações levadas a cabo até o momento não identificaram que empresas que investiram em responsabilidade social tenham tido desempenho financeiro negativo.

Se por um lado os resultados das ações de responsabilidade social são intangíveis e trazem conseqüências nem sempre quantitativas, a falta de investimento nesse 
sentido pode ter um efeito contrário. Galbreath (2006) afirma que a responsabilidade social não pode ser separada da estratégia da empresa, já que ignorá-la pode gerar conseqüências em forma de custos sociais envolvidos na "irresponsabilidade social". Se todas as empresas resolvessem poluir o meio ambiente, fabricar produtos que pudessem causar problemas aos consumidores, ou ainda expor seus funcionários a condições inseguras de trabalho, certamente essas ações gerariam custos.

Nesse sentido, a adoção de práticas de responsabilidade social pode contribuir para os resultados da empresa como um impacto positivo em recompensa por uma postura responsável, ou ainda mitigar as conseqüências de uma ação indevida que possa trazer prejuízos financeiros e à reputação da empresa (BRANCO; RODRIGUES, 2006).

Segundo Branco e Rodrigues (2006), os investimentos em responsabilidade social devem trazer benefícios internos, ajudando a empresa a desenvolver novas capacidades relacionadas à sua cultura e experiência, o que pode acarretar um melhor aproveitamento dos recursos. A contribuição que a responsabilidade social pode promover no desempenho financeiro da empresa é primeiramente relacionada com os fatores qualitativos, como a melhoria nas condições de trabalho dos empregados e na reputação da empresa. Esse processo de transformação afeta positivamente o clima organizacional, diretamente perceptível na avaliação de satisfação dos empregados (BORGER, 2001).

O gerenciamento de recursos humanos pode cortar custos e melhorar a produtividade dos empregados. Ações como o pagamento de um salário justo, condições adequadas de higiene e segurança, oportunidades de treinamento, benefícios em educação e saúde para os empregados e seus familiares, serviços de creche e flexibilidade nos horários de trabalho podem gerar efeitos positivos na motivação dos empregados e em seu comprometimento com a empresa, reduzindo inclusive o turnover e a necessidade de gastos com recrutamento, seleção e treinamento de novos empregados. Podem ainda atrair melhores empregados (BRANCO; RODRIGUES, 2006). 
Ainda segundo Branco e Rodrigues (2006), empresas com uma boa reputação melhoram suas relações com os clientes, investidores, instituições financeiras, fornecedores e concorrentes.

Além dos ganhos com o público interno e melhoria no relacionamento com os clientes, os investimentos em responsabilidade social destinados à gestão ambiental podem resultar em economia associada a um menor gasto com energia e materiais, e também abrir caminhos para a inovação de produtos e processos. $E$ ser uma empresa reconhecida por sua responsabilidade social pode ser muito importante para a entrada em mercados de países desenvolvidos (BRANCO; RODRIGUES, 2006).

A inserção da responsabilidade social na gestão estratégica é um fator que diferencia as empresas e o seu desempenho econômico das demais, se não no curto, no longo prazo (BORGER, 2001).

Mesmo o entendimento do papel das empresas perante a responsabilidade social ter sofrido alterações ao longo do tempo e ainda ser motivo de controvérsias (KITAHARA, 2007), o investimento em ações de responsabilidade social é justificável. Vieira (2007) afirma que "num momento em que já ficou constatado que a iniciativa privada necessita oferecer ao público mais do que bons produtos e serviços devendo estar consoante com o interesse coletivo, tornam-se fator imprescindível para o seu crescimento em todos os níveis a consolidação de uma boa imagem institucional. Caso contrário entrará num processo de entropia e morte".

Ainda segundo Fedato (2005), para as empresas "o tratamento ético de suas relações com o governo, clientes, funcionários e demais públicos é uma necessidade clara, seja por um entendimento por parte dos líderes empresariais de que a boa conduta gera impactos positivos ou pelas pressões exercidas pela sociedade por um desempenho responsável por parte das empresas. Deste modo, a gestão responsável assume uma dimensão estratégica e a atuação social das empresas se torna um mecanismo de participação social das empresas em resposta a demandas da sociedade". 


\subsubsection{A responsabilidade social na gestão das empresas}

Para alcançar uma gestão responsável, a empresa precisa mudar sua cultura organizacional, o que implica mudança em seus valores e práticas (VIEIRA, 2007). Segundo Borger (2001), os princípios de responsabilidade social devem ser incluídos na missão, valores e crenças das empresas, que dessa forma assumirá a responsabilidade das conseqüências de suas operações e atividades.

Para que o processo de adoção de práticas de responsabilidade social realmente faça parte da cultura organizacional da empresa, uma condição importante é o envolvimento da alta direção (BORGER, 2001). Sem o apoio da alta direção, os conceitos e práticas não são disseminados de forma a atingir todos na empresa e as práticas não se enraízam.

Além do envolvimento da alta direção, a empresa precisa também conhecer o seu próprio negócio, pois, segundo Borger (2001), alguns fatores característicos da atividade empresarial certamente direcionarão as ações de responsabilidade social a serem implementadas. Segundo o autor, é de fato importante o conhecimento e o bom entendimento das seguintes informações:

- O setor de atividade da empresa: determina as características operacionais da empresa, como instalações, equipamentos, tecnologia, qualificação do corpo funcional e tipo de fornecedores.

- O porte da empresa: é um fator que determina o desenvolvimento organizacional das empresas e a dimensão dos impactos da atividade empresarial na economia regional, no meio ambiente e nos padrões sociais de comportamento da comunidade.

- A natureza da atividade: determina o potencial poluidor dos processos produtivos e o risco ambiental associados a eles.

- A localização da empresa: determina as relações políticas, sociais e institucionais da empresa e o peso político, econômico e social delas na comunidade.

- O perfil dos clientes.

- A origem do capital. 
Analisar essas características serve como orientação para as ações de responsabilidade social a serem desenvolvidas. Outras referências para implementar ações de responsabilidade social são trazidas no item 2.1.5, quando se discute os referenciais normativos voltados ao tema, em especial os guias.

Na década de 70, Shanklin (1976) já falava sobre a tendência das empresas em investirem em projetos de responsabilidade social com os quais a empresa tivesse alguma equivalência em suas atividades produtivas, evitando dessa forma projetos caros, que acabam tendo suas verbas diminuídas ou mesmo cortadas na antecipação de futuras necessidades de capital. Para isso, a análise do negócio é fundamental. Ferramentas como as normas e metodologias para inclusão da responsabilidade social podem ser bastante úteis nesse processo.

A inclusão da responsabilidade social na estrutura organizacional e nos processos de tomada de decisão da empresa requer investimentos e recursos necessários, como equipe, orçamento e infra-estrutura para desenvolver as atividades (BORGER, 2001). Em vez de incluir a responsabilidade social na estrutura organizacional, as empresas ainda teriam como alternativas a contratação de uma organização especializada para realizar suas práticas de responsabilidade social, ou ainda realizar parcerias em projetos onde não fosse necessária a operacionalização e somente a doação financeira. Porém, segundo Pinheiro Machado (2002) a razão para as empresas internalizarem as suas ações sociais na própria estrutura organizacional são as relações intrínsecas entre a atividade de negócios e o escopo das ações de responsabilidade social implementadas. Para atingir os objetivos da empresa, a preocupação com as partes interessadas e a formulação de ações para atender suas demandas torna-se mais eficiente.

A experiência da $B T$ Global Services ${ }^{6}$ em responsabilidade social, analisada por Blake (2007), sugere que a inserção do tema nos negócios envolve três fases:

1. Fase protetora: onde a empresa adota apenas ações básicas, que se restringem ao cumprimento de leis, regulamentos e normas, porém não garantem que a sua reputação não possa ser colocada em risco.

\footnotetext{
${ }^{6}$ A BT Global Services é uma empresa multinacional fornecedora de soluções corporativas para comunicação (disponível em <www.btglobalservices.com>).
} 
2. Fase construtiva: inicia-se a construção de uma reputação ética, que vai além das exigências legais. Investimentos no público interno da empresa, na diversidade de fornecedores, na comunidade, no suporte à caridade, no uso eficiente dos recursos naturais e cuidado com o meio ambiente são exemplos de ações que podem ser desenvolvidas.

3. Fase inovadora: a responsabilidade social começa a estimular e desenvolver novos negócios, estreitando relações estratégicas e construindo diversidade de mercados. As companhias constroem soluções sustentáveis e parceiras de longo prazo que fazem a diferença com as pessoas com quem trabalham, clientes e fornecedores.

Independente da forma de inserção do tema na gestão dos negócios, a liderança é fator crítico para o engajamento da responsabilidade social, pois as ações e os comportamentos dos líderes pesam significativamente no comportamento dos empregados e fornecem os padrões de conduta e o contexto cultural de atuação para os membros participantes da empresa (BORGER, 2001).

\subsubsection{Os referenciais normativos de responsabilidade social}

A responsabilidade social, discutida há muitos anos por pesquisadores de diversas áreas, atingiu também o âmbito da normalização, quer por meio de normas técnicas, quer de referenciais normativos e guias. Organizações interessadas na disseminação do tema investiram na elaboração de documentos que pudessem orientar as empresas interessadas em incluir a responsabilidade social na gestão de seus negócios a fazê-lo de forma mais objetiva. Esse item apresenta os principais documentos normativos vigentes, referentes exclusivamente ao tema responsabilidade social. Considera-se que os demais documentos existentes de mesma natureza, que abordam temas como satisfação dos clientes, qualidade, meio ambiente e segurança do trabalho, também são de extrema importância para a prática da responsabilidade social, porém não são tratados nessa dissertação. Outras ferramentas de gestão da responsabilidade social, como os Indicadores Ethos de Responsabilidade Social e a Global Reporting Initiative (GRI), serão discutidas no capítulo 3. 


\section{SA 8000}

A SA 8000 - Social Accountability 8000 - é um referencial normativo publicado pela Social Accountability Internacional (SAI), uma organização sem fins lucrativos fundada em 1997 e sediada em Nova lorque, Estados Unidos, dedicada à orientação do tratamento ético dos trabalhadores por todo o mundo. O referencial $S A 8000$ foi publicado em 1997 e revisado em 2001, e possui como objetivos:

a. desenvolver, manter e executar políticas e procedimentos com o objetivo de gerenciar aqueles temas que ela possa controlar ou influenciar;

b. demonstrar para as partes interessadas que as políticas, procedimentos e práticas estão em conformidade com os requisitos da SA 8000 (SAI, 2007).

Este referencial é certificável e baseado nas normas da International Labour Organisation (ILO), na Declaração Universal dos Direitos Humanos e na Convenção da Organização das Nações Unidas (ONU), dos Direitos da Criança.

O referencial $S A 8000$ tem como requisitos de responsabilidade social os seguintes itens:

1. Trabalho infantil: a empresa não deve admitir o trabalho infantil em nenhuma hipótese, somente a jovens acima de 15 anos, com exceção aos países em desenvolvimento onde a faixa etária é de acima de 14 anos.

2. Trabalho forçado: a empresa não deve se envolver com ou apoiar a utilização de trabalho forçado, incluindo a solicitação de "depósitos" ou deixar documentos de identidade por parte dos funcionários quando iniciarem o trabalho com a empresa.

3. Segurança e saúde no trabalho: a empresa deve oferecer um ambiente seguro e saudável de trabalho; deve promover treinamento periódico aos trabalhadores quanto a questões de saúde e segurança, acesso a banheiros limpos e água potável; e também possuir mecanismos para identificação de possíveis focos que possam prejudicar a saúde e segurança dos trabalhadores. 
4. Liberdade de associação e direitos coletivos: a empresa deve respeitar o direito dos trabalhadores de participarem de sindicatos e categorias de classe.

5. Discriminação: a empresa não deve ter ou mesmo apoiar qualquer tipo de discriminação na contratação, remuneração, acesso a treinamento, promoção, encerramento de contrato ou aposentadoria, com base em raça, classe social, nacionalidade, religião, deficiência, sexo, orientação sexual, associação a sindicato ou afiliação política, ou idade. Também não deve permitir comportamentos ameaçadores, abusivos ou exploratórios.

6. Práticas disciplinares: a empresa não deve permitir nenhum tipo de punição corporal, coerção física ou mental, ou ainda abuso verbal.

7. Carga horária de trabalho: a carga horária de trabalho não deve ultrapassar 48 horas semanais, com ao menos um dia de folga no período de sete dias. As horas extras devem ser remuneradas, sem exceder 12 horas por semana.

8. Remuneração: o salário pago aos trabalhadores deve respeitar os padrões legais definidos e ser suficiente para oferecer as necessidades básicas dos trabalhadores e suas famílias. Deduções de salários não devem ser feitas por medidas disciplinares.

9. Sistema de Gestão: a empresa deve investir em um sistema de gestão que garanta o cumprimento dos requisitos da norma e que as ações sejam incorporadas aos sistemas de gestão e práticas da empresa.

A certificação com base nos requisitos do referencial $S A 8000$ é feita por organizações acreditadas pela Social Accountability Internacional (SAI) em todo o mundo. No Brasil, 73 empresas já são certificadas pelo referencial SA 8000 (números de 2007).

\section{AA 1000}

O referencial normativo AA 1000 - AccountAbility 1000 - foi criado pelo ISEA Institute for Social and Ethical Accountability, que é uma organização não governamental com sede em Londres, Reino Unido. Em novembro de 1999, foi 
publicado o guia $A A 1000$ Framework, com o objetivo de nortear o aprendizado, o desempenho e o progresso das organizações, orientando-as em como construir sua responsabilidade social e sua posterior prestação de contas, apontando a necessidade da integração das partes interessadas nas atividades diárias da empresa e orientando o estabelecimento de um processo sistemático de engajamento das partes interessadas para geração de indicadores (ACCOUNTABILITY, 1999).

Outras duas publicações deram seqüência à série de documentos da $A A 1000$ :

- AA 1000AS - Assurance Standard (2003): referencial que avalia a credibilidade dos relatórios de sustentabilidade (ACCOUNTABILITY, 2003);

- AA 1000SES - Stakeholder Engagement Standard (2005): guia que orienta a qualidade da implementação, avaliação, comunicação e garantia do engajamento das partes interessadas (ACCOUNTABILITY, 2005).

Na versão brasileira do referencial, manteve-se o termo accountability sem tradução, pela falta de consenso na tradução do termo como 'responsabilidade final', que pode não traduzir integralmente o conceito que o documento reflete (ACCOUNTABILITY, 2002).

Os padrões de processo do referencial $A A 1000$ passam pelos seguintes estágios:
a. Planejamento;
b. Contabilidade;
c. Auditoria e balanço;
d. Integração;
e. Engajamento com partes interessadas.

O foco do referencial é a melhoria do desempenho geral das empresas de todos os portes e atividades, e esse desempenho pode ser medido em diversas áreas da empresa, como na gestão da qualidade, no recrutamento e retenção de funcionários, no engajamento de partes interessadas externas, nas parcerias, no gerenciamento de riscos, nas relações com investidores, na governança corporativa, nas relações 
com o governo e nos treinamentos. O AA1000 é um referencial normativo de processo, não é um padrão de desempenho real. Ou seja, ele especifica os processos que uma organização deve seguir para fazer o relato de seu desempenho, e não os níveis de desempenho que a organização deve atingir. $O$ referencial $A A 1000$ é dividido conforme a estrutura da figura 2.

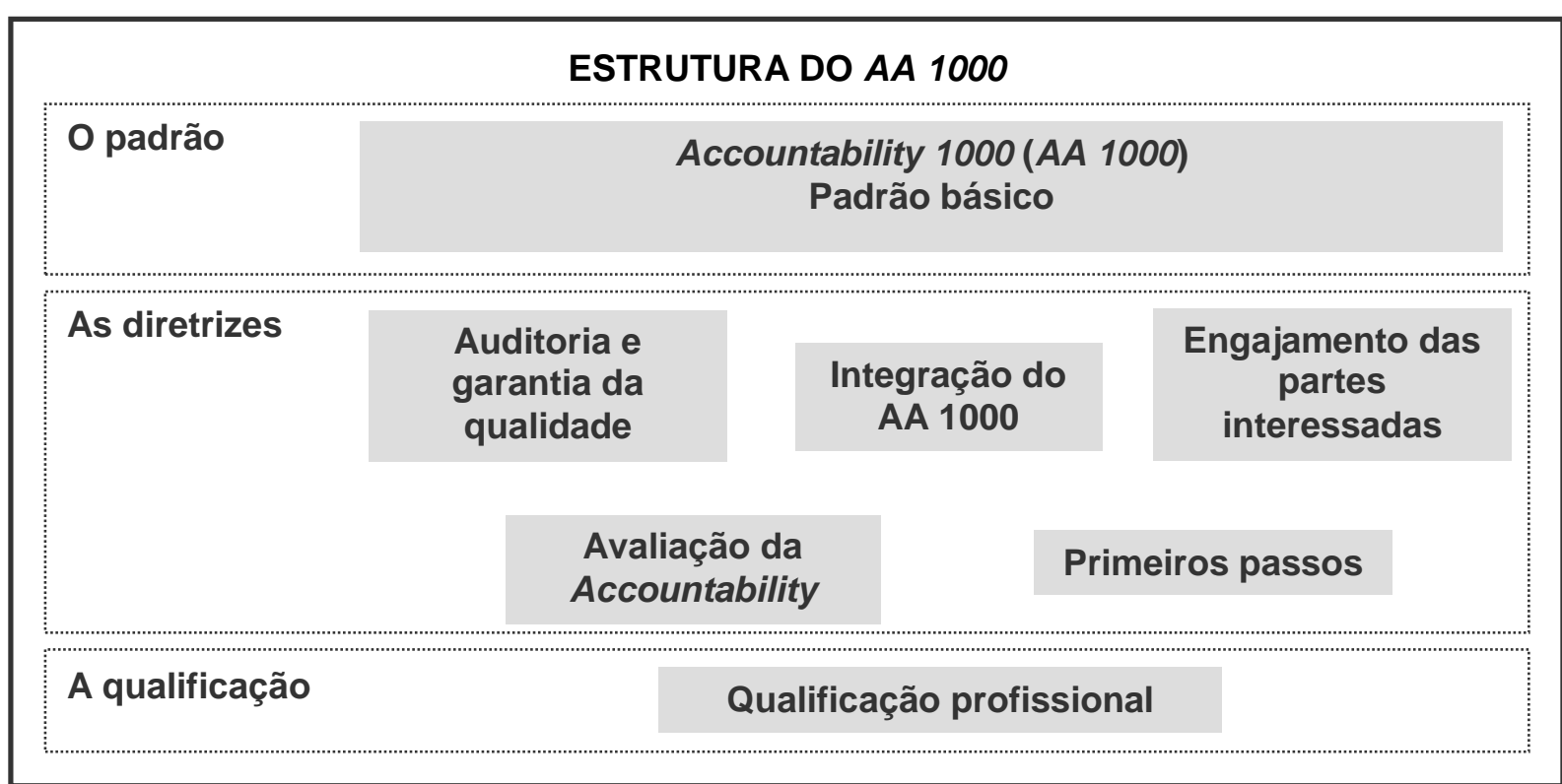

Figura 2 - Estrutura do referencial AA 1000 (Adaptado de Accountability, 1999)

As diretrizes de auditoria e garantia de qualidade definem os princípios necessários para a condução de uma auditoria social e ética. O referencial AA1000 foi desenhado para integrar qualidade, e também para operar como um sistema único para a contabilidade, auditoria e relato social e ético. O engajamento das partes interessadas significa a utilização da liderança das organizações para construir relacionamentos com partes interessadas e, portanto, melhorando sua accountability e desempenho. A metodologia do referencial AA1000 pode ser adotada gradualmente e servir de modelo a ser atingido ao longo do tempo. O documento sugere um conjunto de primeiros passos, com considerações para a organização em cada um deles. A estrutura do referencial $A A 1000$ também incorpora diretrizes para qualificação profissional ligadas a um programa de treinamento e de desenvolvimento profissional para os que trabalharão diretamente com a metodologia e também para os auditores do sistema. 
O atendimento ao referencial $A A 1000$ nas organizações se divide em um fluxo de cinco partes, como mostra a figura 3.

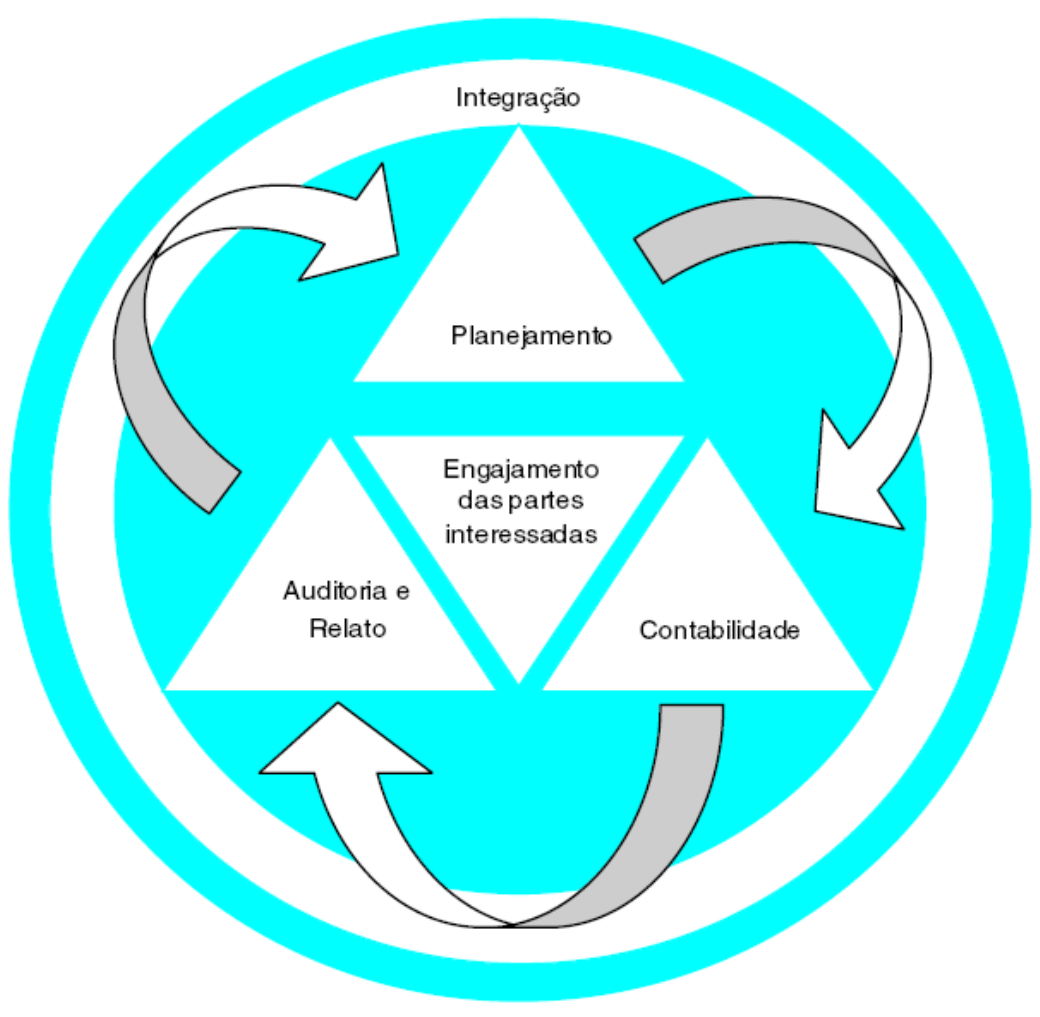

Figura 3 - O modelo do processo do referencial AA 1000 (ACCOUNTABILITY, 1999)

O processo de implantação e operação do referencial $A A 1000$ passa por 12 etapas, divididos nas cinco fases do fluxo da metodologia, da seguinte forma:

\section{Na fase de Planejamento:}

1. Estabelecimento de procedimentos de engajamento e governança.

2. Identificação das partes interessadas.

3. Definição/revisão de valores da organização.

\section{Na fase de Contabilidade:}

4. Identificação de temas críticos junto às partes interessadas.

5. Determinação do escopo do processo (unidades operacionais e questões a serem incluídas, como considerar as partes interessadas, prazo do ciclo atual, método de auditoria, escopo da auditoria e auditor). 
6. Identificação de indicadores (indicadores sociais e éticos para avaliar desempenho da organização em relação a seus valores e objetivos; os valores e aspirações de suas partes interessadas).

7. Coleta de informações (sobre seu desempenho em relação aos indicadores identificados).

8. Análise das informações, estabelecimento metas e desenvolvimento do plano de melhoria.

\section{Na fase de Auditoria e Relato:}

9. Preparação do relato social.

10. Auditoria do relato social.

11. Comunicação do relato e obtenção de retorno.

\section{Na fase de Integração:}

12. Estabelecimento e integração de sistemas (estabelecimento de sistemas para apoiar o processo e o alcance contínuo de seus objetivos e metas alinhados com seus valores).

A fase de Engajamento das Partes interessadas permeia todo o processo, pois é o foco central do referencial, ou seja, integra as partes interessadas na gestão da organização.

A empresa de consultoria BSD ainda propõe outra estrutura de fluxo para representar o modelo do referencial $A A 1000$, conforme a figura 4 (BSD, 2007). 


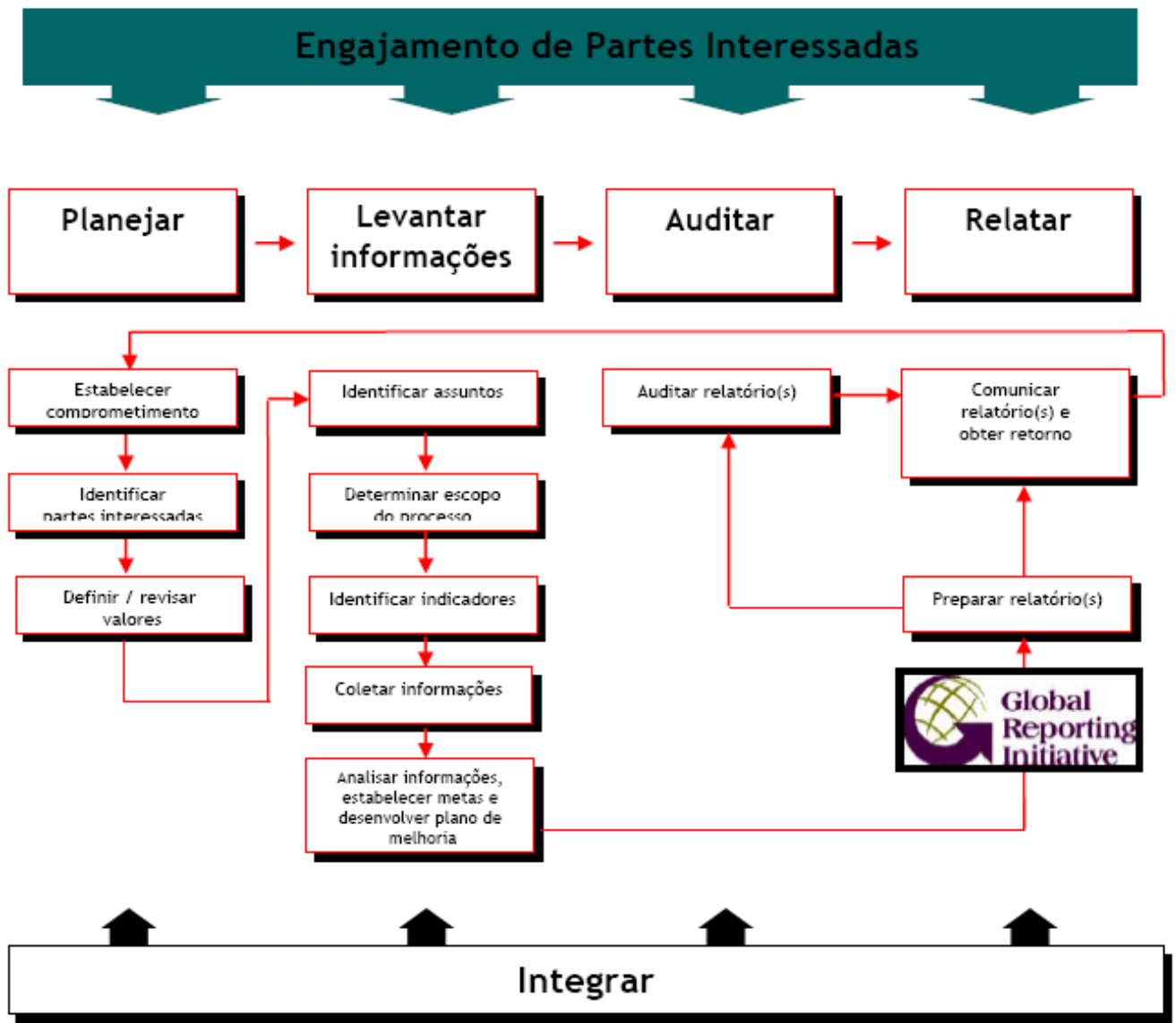

Figura 4 - Modelo de processo do referencial AA 1000 (BSD, 2007)

\section{SD 21000}

O guia francês SD 21000 Guide, publicado em 2003 pela Association Française de Normalisation (AFNOR), tem por objetivo orientar os tomadores de decisão de grandes ou pequenas empresas, de origem pública ou privada de todos os setores da economia, a iniciar a discussão da consideração do desenvolvimento sustentável no estabelecimento de estratégias nas dimensões econômica, ambiental e social (AFNOR, 2003).

Propõe um sistema de gestão não certificável que gradativamente integra os objetivos do desenvolvimento sustentável, podendo ser adaptável aos sistemas de gestão da qualidade e meio ambiente que já estejam implementados nas empresas. Nota-se assim que o guia SD 21000 não fala especificamente de responsabilidade social, mas amplia seu escopo referindo-se ao desenvolvimento sustentável. 
A estrutura do guia está dividida nos seguintes itens:

1. Desenvolvimento sustentável: origem e definição

2. Considerando o princípio do desenvolvimento sustentável: uma abordagem diferente para cada empresa

3. As conseqüências para as empresas

4. A abordagem estratégica

5. Implementando a abordagem

Anexo A: Glossário

Anexo B: Exemplo das expectativas das partes interessadas das empresas

O guia traz a história do nascimento e da rápida expansão do conceito de desenvolvimento sustentável; as conseqüências mais prováveis no planeta das atividades das empresas, em particular, lembrando a responsabilidade das mesmas com o futuro do planeta; e a tendência das empresas em estabelecer políticas e estratégias para uma atuação mais sustentável.

O primeiro item do guia define os conceitos do desenvolvimento sustentável desde sua origem, e fala de assuntos como a exploração do planeta Terra, a preservação de recursos naturais, poluição, o aspecto humano, o modelo de desenvolvimento e as implicações do conceito de desenvolvimento sustentável para as empresas.

A adoção dos conceitos de sustentabilidade é uma experiência diferente para cada empresa. O segundo item do guia fala sobre esse processo de aprendizagem, onde se propõe uma análise estratégica da empresa ao responder questões como:

- Quais as razões que justificam o esforço de considerar as demandas das partes interessadas na gestão?

- Por que ter um comportamento diferente para respeitá-las?

- Quem são essas partes interessadas? 
- Quais são as demandas das partes interessadas? Por que há um crescimento da influência dessas partes interessadas no desempenho das empresas?

- Quais podem ser os impactos dessas influências (positivas ou negativas) no desempenho das empresas? Hoje? No futuro? Os riscos? Em quais setores?

Não há uma resposta pronta para essas questões. As empresas devem se engajar no exercício de determinar suas próprias estratégias para gerenciar as interfaces econômico-social (governança corporativa e participação dos funcionários nos lucros da empresa), econômico-ambiental (economia de recursos e análise do ciclo de vida dos produtos) e social-ambiental (higiene, segurança e aspectos de saúde) condizentes com a sua realidade.

As conseqüências de adotar a sustentabilidade na gestão são apresentadas no item 3 do guia, e são divididas em:

- os ganhos para a empresa;

- as principais dificuldades iniciais (como as dificuldades em fixar os objetivos, dificuldades de gerenciar as mudanças e os investimentos ao longo do tempo, dificuldades de gerenciar a inovação e as mudanças necessárias);

- a evolução nas práticas gerenciais e na cultura da empresa (como a formalização das práticas gerenciais, os princípios da gestão, o sistema de gestão);

- os caminhos para a integração das dimensões sociais e ambientais na gestão.

Para adoção da responsabilidade social na gestão, o item 4 do guia apresenta uma estratégia conforme os passos descritos a seguir:

- inicialmente é necessária uma atualização dos princípios e práticas da governança corporativa da empresa, adaptando tudo aquilo que estiver em seu escopo (como estrutura, regras e procedimentos) de forma a estarem 
alinhados com o conceito da responsabilidade social. Também é necessária a revisão dos valores da empresa e o comprometimento da alta direção para que o que é planejado esteja alinhado ao que resulta como produto final da empresa.

- Outro passo importante é conhecer as partes interessadas internas e externas que podem afetar ou serem afetadas pelas atividades da empresa, identificá-las, entendê-las e organizá-las dentro de uma hierarquia de expectativas. Deve-se também estimar as condições de cada parte interessada em influenciar (positivamente ou negativamente) o desempenho da empresa, e como a empresa pode ter um impacto positivo ou negativo dessas partes interessadas. Deve ser verificada também a coerência entre os valores definidos para a gestão da empresa e as novas demandas das principais partes interessadas (se necessário adaptá-las) e investir em relações de parceria com elas. É necessário ainda criar indicadores para monitorar o desempenho econômico, social e ambiental da empresa e comunicá-los periodicamente às partes interessadas envolvidas, por meio de uma comunicação transparente e honesta.

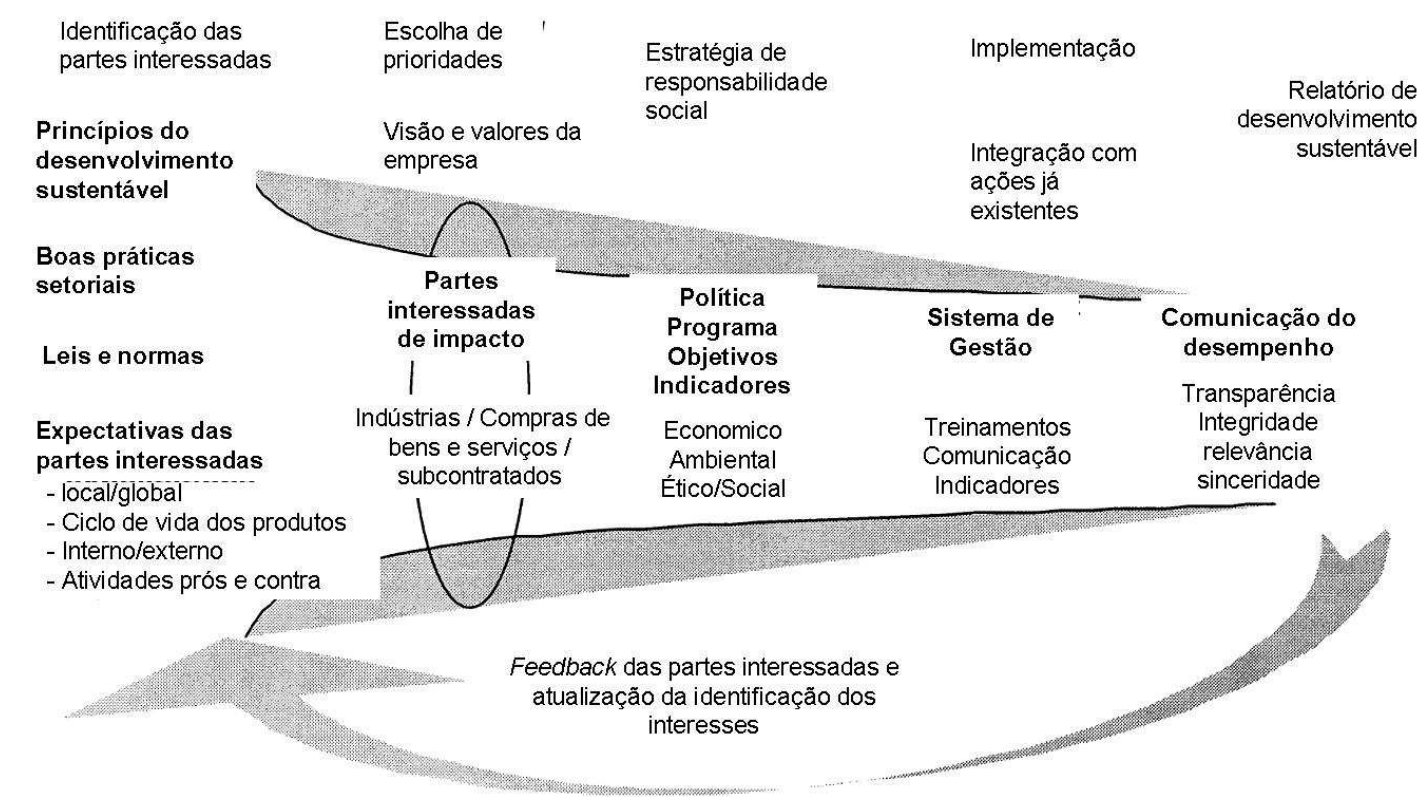

Figura 5 - Modelo para gestão das partes interessadas (AFNOR, 2003)

- Outros fatores, como os princípios universais, leis nacionais e internacionais, convenções e acordos e os direitos humanos, devem ser 
considerados na criação da estratégia para uma atuação socialmente responsável.

- Devem ser priorizados os assuntos críticos para dar início a uma atuação socialmente responsável, e essa análise será diferente para cada negócio ou atividade das empresas.

Para implementação efetiva da responsabilidade social, o guia SD 21000 apresenta um sistema de gestão no item 5, deixando claro que o desempenho da empresa vai depender da implementação do modelo de gestão e também de sua melhoria contínua, que irá contribuir na eficiência estratégica e operacional de seus processos e produtos.

O sistema de gestão segue a estrutura:

\subsection{Responsabilidade da alta direção}

5.1.1 Papel da alta direção

5.1.2 Desenvolvimento do sistema de governança

5.1.3 Comprometimento e envolvimento da alta direção

5.1.4 Definição do plano de ação

5.1.5 Programa do plano de ação para um período de três a cinco anos

\subsection{Plano inicial para ação}

5.2.1 Estruturação do plano inicial

5.2.2 Plano final

\subsection{Implementação e o monitoramento do plano de ação}

5.3.1 Monitoramento e a mensuração dos impactos significativos

5.3.2 Indicadores de desenvolvimento sustentável

5.3.3 Análise crítica

5.3.4 Melhoria contínua

5.3.5 Dimensão cultural das adaptações 


\subsection{Funções e setores específicos}

5.4.1 Gestão de infra-estruturas e equipamentos

5.4.2 Projeto de produtos e serviços

5.4.3 Gestão de suprimentos, subcontratados e parceiros

5.4.4 Gestão da informação e comunicação

O guia ainda apresenta dois anexos, sendo o anexo $A$ um glossário e o anexo $B$ um exemplo de levantamento das expectativas e necessidades das partes interessadas.

\section{NBR 16001}

A Norma Brasileira ABNT NBR 16001 Responsabilidade Social - Sistema de gestão - Requisitos, publicada em 2004 pela Associação Brasileira de Normas Técnicas (ABNT), ter por objetivo "estabelecer os requisitos mínimos relativos a um sistema da gestão da responsabilidade social, permitindo à organização formular e implementar uma política e objetivos que levem em conta os requisitos legais e outros, seus compromissos éticos e sua preocupação com a promoção da cidadania, a promoção do desenvolvimento sustentável e a transparência das suas atividades", e ainda "prover às organizações os elementos de um sistema da gestão da responsabilidade social eficaz, passível de integração com outros requisitos de gestão, de forma a auxiliá-las a alcançar seus objetivos relacionados com os aspectos da responsabilidade social. [...]" (ABNT, 2004).

A NBR 16001 foi elaborada para ser aplicada em todos os tipos e portes de empresas e organizações, seguindo os padrões da International Organization for Standardization (ISO), e também segue a metodologia PDCA (plan, do, check, act) com foco na melhoria contínua.

As organizações que tenham por objetivo implantar, manter e aprimorar um sistema de gestão da responsabilidade social, assegurar-se de sua conformidade com a legislação vigente e apoiar o engajamento das partes interessadas podem utilizar a NBR 16001. Podem ainda comprovar a equivalência dessas ações em conformidade com os requisitos da norma, já que a NBR 16001 é certificável. 
Como todas as normas de sistema de gestão, a sua adoção não garante, por si só, resultados ótimos (ZACHARIAS, 2004). Ainda segundo Zacharias (2004), o sistema de gestão da responsabilidade social deve estimular as organizações a considerarem a implementação da melhor prática disponível para o atendimento dos requisitos, com a devida análise de viabilidade.

A NBR 16001 está dividida nos seguintes requisitos:

- Requisitos gerais;

- Política da responsabilidade social;

- Planejamento;

- Implementação e operação;

- Requisitos de documentação e;

- Medição, análise e melhoria.

Nos requisitos gerais, a organização deve estabelecer, implementar, manter e continuamente aprimorar um sistema de gestão da responsabilidade social. Um ponto importante da norma é que não são aceitas exclusões de requisitos para efeitos de certificação.

A política de responsabilidade social deve ser elaborada pela alta administração da organização, considerando a natureza, escala e impactos da organização; a promoção da ética e do desenvolvimento sustentável; o comprometimento com a melhoria contínua, a prevenção de impactos e o atendimento a legislação. Ainda quanto à política, as partes interessadas devem ser consultadas para sua validação, e posteriormente a mesma deve ser documentada, implementada e mantida, e também comunicada para todos os colaboradores da organização.

$\mathrm{Na}$ etapa de planejamento, a organização deve criar e manter procedimentos de mapeamento das partes interessadas, de forma a conseguir identificar os aspectos que possam ser controlados, evitando impactos negativos a elas causados. Deve também padronizar a forma de acesso aos requisitos legais referentes aos aspectos da responsabilidade social. Os objetivos e metas a serem elaborados devem considerar a prática da ética e o desenvolvimento sustentável, por meio de ações 
como combate à pirataria, respeito aos direitos da criança e do adolescente, promoção da saúde e segurança, entre outros. O fundamental é que aos objetivos e metas sejam atribuídos meios e prazos nos quais devem ser atingidos e também responsáveis para seu cumprimento.

Já em relação à implementação e operação, a organização deve inicialmente promover a capacitação de seus colaboradores para a operação do sistema, considerando os aspectos contidos no escopo do planejamento. Os colaboradores também devem ser conscientizados da importância da conformidade com a política de responsabilidade social, dos impactos provenientes da adoção da norma na empresa, das suas funções e responsabilidades para atingir a conformidade e atendimento aos requisitos, e também das conseqüências do não cumprimento dos procedimentos do sistema de gestão da responsabilidade social. A comunicação deve ser estabelecida para todos os colaboradores da organização e estendida para as partes interessadas, inclusive criando um canal de recebimento, documentação e resposta às suas solicitações. O controle operacional deve ser realizado, com a criação, implementação e manutenção de procedimentos relativos aos aspectos previstos no planejamento.

Os requisitos de documentação são similares aos padrões utilizados na NBR ISO 9001 - Sistemas de gestão da qualidade - Requisitos e NBR ISO 14001 - Sistemas da gestão ambiental - Requisitos com orientações para uso, e devem incluir declarações documentadas da política de responsabilidade social, seus objetivos e metas; manual do sistema de gestão da responsabilidade social; procedimentos documentados, documentos e registros requeridos pela NBR 16001 e procedimentos documentados, documentos e registros definidos pela organização como necessários para operação do sistema de gestão da responsabilidade social. Todos os controles de documentos e registros devem ser descritos por meio de procedimentos para a garantia da gestão das informações referentes ao sistema.

As medições feitas pela organização devem incluir o registro de informações referentes ao acompanhamento de desempenho e a conformidade com os objetivos e metas da responsabilidade social. A análise desses registros resulta em uma avaliação de conformidade ou não-conformidade com os procedimentos do sistema e, no caso de não conformidades, as mesmas, além de corrigidas, devem ser 
investigadas e promovidas as devidas ações corretivas e preventivas. A realização de auditorias internas periódicas é necessária para avaliação da eficiência do sistema e a identificação de possíveis falhas e possibilidades de melhoria. Paralelamente às auditorias internas, a alta administração deve analisar o sistema periodicamente para proposição de melhorias e necessidades de mudança.

A NBR 16001 apresenta uma estrutura bastante semelhante às normas consagradas para gestão da qualidade e meio ambiente, porém ainda encontra-se com um índice baixo de certificação.

\section{ISO 26000}

A ISO 26000 - Guidance on Social Responsibility é uma norma que está sendo desenvolvida pela Internacional Organization for Standardization (ISO), e que fará parte da terceira geração de normas ISO, juntamente com as normas de gestão da qualidade (ISO 9000) e de gestão ambiental (ISO 14000). As fontes de informação para a elaboração da descrição dessa norma são indiretas, já que o documento ainda se encontra em elaboração, o que resulta aqui em uma visão mais simplificada da ISO 26000.

Diferentemente das demais normas da International Organization for Standardization (ISO), a ISO 26000 será uma norma de diretrizes para responsabilidade social não certificável. Sua publicação está prevista para 2009.

O Brasil é um dos países participantes do Working Group, representado pela Associação Brasileira de Normas Técnicas (ABNT).

Segundo Thiago (2006), em setembro de 2002, o conselho da International Organization for Standardization (ISO) criou um grupo estratégico consultivo (SAG) para aprofundar o tema responsabilidade social. Em junho de 2004, a ISO decidiu pela elaboração da norma de responsabilidade social, e, em janeiro de 2005, iniciou os trabalhos do Work Group Social Responsibility (WG SR). O Brasil, representado pela Associação Brasileira de Normas Técnicas (ABNT), foi nomeado líder do grupo juntamente com a Suécia, representada pelo Swedish Standards Institute (SIS), num processo de alternância, onde a liderança estratégica e política do processo é dividida entre um país em desenvolvimento e um país desenvolvido. 
A primeira reunião plenária do grupo de trabalho foi realizada em março de 2005 em Salvador, Brasil. As demais reuniões foram realizadas em Bangkok, Tailândia (setembro de 2005), Lisboa, Portugal (maio de 2006), Sydney, Austrália (janeiro e fevereiro de 2007), Viena, Áustria (novembro de 2007).

Segundo Thiago (2006), os benefícios esperados com a criação dessa norma são:

- facilitar o estabelecimento de um marco de referência em responsabilidade social;

- prover um "entendimento comum" sobre a responsabilidade social em um nível global;

- aumentar a conscientização sobre a responsabilidade social e a prática de princípios universais acordados;

- reunir experiências e expertise, promovendo boas práticas, nivelando o assunto globalmente;

- aumentar a capacidade de participação dos países menos desenvolvidos.

A norma terá como escopo:

- auxiliar uma organização a tratar de suas responsabilidades sociais;

- prover orientação prática com respeito a:

- operacionalização da responsabilidade social,

- identificação e engajamento das partes interessadas e

- aumento da credibilidade de relatórios e reivindicações sobre responsabilidade social;

- enfatizar resultados de desempenho e melhorias;

- aumentar a satisfação e a confiança do usuário;

- promover terminologia comum no campo da responsabilidade social; 
- ser consistente e não conflitar com documentos, tratados, convenções e outras normas ISO existentes (THIAGO, 2006).

A estrutura da norma é dividida da seguinte forma:

0. Introdução (Introduction)

1. Escopo (Scope)

2. Referências normativas (Normative references)

3. Termos e definições (Terms and definitions)

4. O contexto da responsabilidade social no qual as organizações operam (The SR context in which organizations operate)

5. Os princípios de responsabilidade social relevantes para as organizações (SR principles relevant to organizations)

6. Guia de temas centrais da responsabilidade social (Guidance on core SR subjects/issues)

7. Guia para implementação da responsabilidade social nas organizações (Guidance for organizations on implementing SR)

8. Guias anexos (Guidance annexes)

Percebe-se assim que o documento, além de uma norma propriamente dita, traz também um guia de aplicação.

Ainda é muito cedo para avaliar quais serão os impactos da publicação dessa norma, que tem como prazo 30 de novembro de 2009 (ISO, 2007). No entanto, a grande expectativa está em como a responsabilidade social será tratada, com tantas desigualdades entre os diversos países. Ursini e Sekiguchi (2005) discutem uma série de desvantagens associadas à elaboração de uma norma de responsabilidade social internacional, e citam que "ao buscar consenso, o processo de construção de uma norma internacional de responsabilidade social poderá reduzir demais o patamar desejável de um sistema de gestão de responsabilidade social". Outros aspectos importantes levantados por Ursini e Sekiguchi (2005) são a possibilidade de uma norma muito abrangente não considerar as particularidades culturais e éticas 
de países e povos, e também reduzir a utilização de metodologias já aplicadas atualmente nas organizações, como as dos referenciais normativos AA 1000 e SA 8000 , entre outras.

\subsection{Ações de responsabilidade social no setor da construção de edifícios}

O setor da construção de edifícios, caracterizado por suas atividades de grande impacto ambiental, mão-de-obra desqualificada, condições ruins de trabalho, alta informalidade, etc., possui um papel importante no cumprimento de ações que vão além das obrigações empresariais para a melhoria das condições de trabalho e atendimento das necessidades das partes interessadas.

Mesmo diante desse cenário, o tema da responsabilidade social ainda encontra-se pouco disseminado na construção civil. Associações representativas do setor, como o Sindicato das Empresas de Compra, Venda, Locação e Administração de Imóveis Residenciais e Comerciais de São Paulo (Secovi) e o Sindicato da Indústria da Construção Civil do Estado de São Paulo (Sinduscon-SP), ainda possuem poucos programas direcionados a essa questão, que a cada dia torna-se mais evidente nos diversos setores da economia. Em contrapartida, existem empresas que já investem em responsabilidade social, executando projetos com objetivos diversos, visando atender as demandas de suas partes interessadas.

Esse cenário demonstra que a consideração das partes interessadas na gestão estratégica das empresas ainda não é evidente e tampouco uma prática consolidada, já que os problemas inerentes ao setor ainda são bastante representativos. Por outro lado, os investimentos em responsabilidade social no setor da construção civil caracterizam-se por seu cunho social e assistencialista, talvez por uma interpretação restrita do conceito da responsabilidade social em si por parte das empresas, o que também pode acarretar em uma não divulgação de outras ações que se enquadrariam na agenda da responsabilidade social, porém não são classificadas como tal.

Os exemplos de ações de responsabilidade social no setor da construção de edifícios são muitos, porém a divulgação dessas ações é feita, na maioria das vezes, 
pelas próprias empresas autoras. Para levantar o perfil das ações que vem sendo desenvolvidas no setor, foi realizada uma pesquisa nos sítios das empresas incorporadoras e construtoras brasileiras atuantes no setor habitacional listadas no ranking da ITCnet $^{7} 2007$. Os sítios de todas as empresas listadas no ranking foram visitados entre os meses de abril e maio de 2008, e buscou-se agrupar as ações similares de diferentes empresas para evidenciar a incidência das mesmas no setor, conforme apresentado na tabela 1. Das 100 empresas listadas no ranking, 97 possuíam página na internet (as 3 restantes não estavam disponíveis ou estavam em construção na ocasião da pesquisa), e 49 das empresas utilizam a internet como meio de divulgação de suas ações de responsabilidade social. As empresas que divulgaram a realização de ações de responsabilidade social, mas que não descreveram nenhuma delas, foram consideradas como se não desenvolvessem tais ações, em função da falta de informações suficientes para caracterização das mesmas.

Em função da inviabilidade de verificação do efetivo cumprimento e desempenho das ações de responsabilidade social divulgadas nos sítios da internet das incorporadoras e construtoras pesquisadas, as ações levantadas nessa dissertação não foram vinculadas às empresas que às promovem, a fim de não comprometer o caráter de veracidade que se pretende manter para as informações aqui divulgadas.

Analisando o perfil das ações de responsabilidade social promovidas pelas empresas do setor da construção de edifícios listadas da tabela 1, percebe-se que a capacitação dos fornecedores não se encontra na pauta atual. Esse fato pode ser decorrente da dificuldade de viabilizar essas ações e também dos custos envolvidos para sua operacionalização.

Deve-se notar que a ação mais citada, no caso dos resíduos de construção e demolição, é de caráter obrigatório devido à imposição da Resolução Conama 307 (2002). Diante das 100 empresas pesquisadas, que as construtoras que não a citaram não o fizeram por considerá-la obrigatória ou por não praticá-la.

\footnotetext{
7 A ITCnet é especializada em pesquisa de mercado de obras nos setores de edificações e construção pesada no Brasil e há mais de 28 anos acompanha a evolução do setor da construção, por meio de pesquisas de novos empreendimentos nos segmentos: residencial, comercial e industrial, com amplo detalhamento.Disponível em <www.itc.etc.br $>$.
} 
Tabela 1 - Ações de responsabilidade social das 100 empresas incorporadoras e construtoras do Ranking ITCnet 2007

\begin{tabular}{|c|c|}
\hline AÇÃO & $\begin{array}{l}\text { INCIDËNCIA NA } \\
\text { AMOSTRAGEM }\end{array}$ \\
\hline Coleta seletiva e gestão de resíduos & 24 \\
\hline Alfabetização nos canteiros de obras & 16 \\
\hline Auxílio financeiro a instituições e ONGs & 12 \\
\hline Revitalização de áreas (entorno dos empreendimentos e áreas diversas) & 10 \\
\hline Construção e reformas de sedes de instituições e ONGs & 8 \\
\hline Inclusão de jovens carentes no mercado profissional - primeiro emprego & 7 \\
\hline $\begin{array}{l}\text { Campanha de saúde nos canteiros de obras (medicina preventiva, palestras sobre doenças, } \\
\text { campanhas de vacinação) }\end{array}$ & 6 \\
\hline Racionalização de recursos (água, energia e materiais) nos canteiros de obras & 5 \\
\hline $\begin{array}{c}\text { Aproximação da comunidade do entorno dos empreendimentos para esclarecimentos sobre } \\
\text { a obra }\end{array}$ & 5 \\
\hline Programas de qualificação profissional para os funcionários dos canteiros de obras & 5 \\
\hline Adoção de alternativas sustentáveis para projetos (reaproveitamento de água de chuva, etc.) & 4 \\
\hline Arrecadação de itens para doação a instituições e ONGs & 4 \\
\hline Palestras educativas em escolas e distribuição de material educativo sobre meio ambiente & 3 \\
\hline Preservação de áreas verdes nos empreendimentos e plantio de mudas nativas & 3 \\
\hline $\begin{array}{c}\text { Ações com a sociedade (incentivo a abolição do trabalho infantil, campanhas de combate à } \\
\text { exploração sexual) }\end{array}$ & 3 \\
\hline Incentivo à arte e cultura para funcionários dos canteiros de obras & 3 \\
\hline $\begin{array}{c}\text { Apoio a recuperação de jovens e adultos carentes moradores de rua (educação e } \\
\text { reintegração à sociedade) }\end{array}$ & 2 \\
\hline Participação e premiação em concursos de responsabilidade social & 2 \\
\hline Incentivo a arte e cultura para população carente e ONGs & 2 \\
\hline Desenvolvimento das comunidades no entorno dos empreendimentos & 2 \\
\hline Certificação ambiental para os empreendimentos & 2 \\
\hline Visitas dos familiares dos funcionários das obras ao canteiro & 2 \\
\hline Campanha de doação de sangue & 2 \\
\hline Inclusão digital para operários nas obras (disponibilização de acesso a internet) & 2 \\
\hline Incentivo ao voluntariado & 2 \\
\hline Utilização de materiais sustentáveis & 1 \\
\hline Divulgação de indicadores sociais & 1 \\
\hline Patrocínio a esportes & 1 \\
\hline Projetos de qualidade de vida para colaboradores & 1 \\
\hline Biblioteca nos canteiros de obras & 1 \\
\hline Alfabetização digital (curso de informática para operários) & 1 \\
\hline Alfabetização digital para comunidade carente & 1 \\
\hline Auxílio para compra de materiais escolares & 1 \\
\hline Incentivo à cultura (pesquisa sobre a região do empreendimento e posterior divulgação) & 1 \\
\hline Diagnósticos de impactos ambientais e medidas para sua redução & 1 \\
\hline Apoio da equipe de obra na reforma das casas dos próprios funcionários & 1 \\
\hline Melhoria das áreas de vivência dos canteiros de obra & 1 \\
\hline Doação de computadores & 1 \\
\hline Promoção de competições esportivas para integrar funcionários & 1 \\
\hline Utilização dos Indicadores Ethos de Responsabilidade Social & 1 \\
\hline
\end{tabular}

As empresas que investem em responsabilidade social têm ainda no mercado o seu reconhecimento por meio de premiações promovidas por entidades de classe. Uma delas é o Prêmio CBIC de Responsabilidade Social, promovido pelo Fórum de Ação Social e Cidadania da Câmara Brasileira da Indústria da Construção (CBIC), que visa "fortalecer e estimular o desenvolvimento de ações sociais no setor da Indústria da Construção e do Mercado Imobiliário, criando um mecanismo de reconhecimento dos esforços conjuntos do setor na busca por uma sociedade com melhor qualidade 
de vida; disseminar a cultura da Responsabilidade Social no setor, por meio do debate sobre o tema, ressaltando sua importância para toda a sociedade, especialmente entre os atuantes no setor da Indústria da Construção e do Mercado Imobiliário e; promover intercâmbio de informações com as organizações dedicadas ao tema da Responsabilidade Social, construindo uma fonte permanente de informações e notícias das ações sociais do setor" (CBIC, 2007).

Tabela 2 - Principais ações premiadas pelo Prêmio CBIC de Responsabilidade Social nas edições de 2005, 2006 e 2007 (CBIC, 2008)

\begin{tabular}{|c|c|c|c|}
\hline AÇĀO & ANO & EMPRESA & DESCRIÇĀO \\
\hline $\begin{array}{l}\text { Profissionalização de } \\
\text { menores }\end{array}$ & 2005 & Sicepot-MG & $\begin{array}{c}\text { Capacitação e qualificação de jovens de } 16 \text { a } 21 \text { anos para } \\
\text { ingresso no mercado de trabalho, gerando aumento na renda } \\
\text { familiar para os trabalhadores e promovendo a inclusão social } \\
\text { de jovens de baixa renda. }\end{array}$ \\
\hline Brechó da construção & 2005 & Sicepot-MG & $\begin{array}{l}\text { Destinação mais responsável às sobras de materiais de } \\
\text { construção, favorecendo uma parcela mais necessitada da } \\
\text { sociedade. }\end{array}$ \\
\hline $\begin{array}{l}\text { Oficina de Reciclagem de } \\
\text { resíduos sólidos na } \\
\text { indústria da Construção } \\
\text { Civil }\end{array}$ & 2005 & Cipesa S.A. & $\begin{array}{l}\text { Oficina de arte com matérias-primas doadas, para aumento da } \\
\text { auto-estima e incentivo na renda familiar dos participantes. }\end{array}$ \\
\hline $\begin{array}{l}\text { Projeto Instituto Rogério } \\
\text { Steinberg }\end{array}$ & 2005 & $\begin{array}{l}\text { Servenco } \\
\text { S.A. }\end{array}$ & $\begin{array}{c}\text { Educação de crianças e adolescentes menos favorecidos, } \\
\text { despertando e desenvolvendo talentos por meio de atividades } \\
\text { de arte, música, dança, teatro, capoeira, informática, iniciação } \\
\text { esportiva, recreação, artesanato, pintura em tecido, estimulação } \\
\text { de bebes e brinquedoteca. }\end{array}$ \\
\hline $\begin{array}{l}\text { Projeto Construção } \\
\text { Solidária }\end{array}$ & 2005 & $\begin{array}{l}\text { Goldsztein } \\
\text { S.A. }\end{array}$ & $\begin{array}{c}\text { Beneficiar empregados que possuem residências em situações } \\
\text { precárias, por meio de mutirão, onde operários voluntários e } \\
\text { empresas parceiras iniciam a obra, executada com materiais } \\
\text { aproveitados da própria empresa e alguns doados por } \\
\text { fornecedores. }\end{array}$ \\
\hline $\begin{array}{l}\text { Programa Qualidade de } \\
\text { Vida na Construção }\end{array}$ & 2006 & $\begin{array}{l}\text { Sinduscon- } \\
\text { CE }\end{array}$ & $\begin{array}{c}\text { Promover a consciência crítica cidadã, ações sociais de apoio a } \\
\text { instituições beneficentes e ações para funcionários das } \\
\text { empresas. }\end{array}$ \\
\hline $\begin{array}{l}\text { Projeto Dia da Ação } \\
\text { Social e Cidadania }\end{array}$ & 2006 & $\begin{array}{l}\text { Sinduscon- } \\
\text { PE }\end{array}$ & $\begin{array}{c}\text { Promover atendimentos de saúde e cidadania, acarretando a } \\
\text { melhoria da qualidade de vida com atividades de exames e } \\
\text { consultas, palestras sócio-educativas, cidadania, atendimento } \\
\text { odontológico e atividades de lazer. }\end{array}$ \\
\hline $\begin{array}{l}\text { Projeto Labomar - Cultivo } \\
\text { Comunitário de Ostras }\end{array}$ & 2006 & $\begin{array}{l}\text { Alphaville } \\
\text { Urbanismo } \\
\text { S.A. }\end{array}$ & $\begin{array}{l}\text { Desenvolvimento sustentável das comunidades localizadas em } \\
\text { regiões próximas aos empreendimentos, por meio de } \\
\text { capacitação e treinamento. }\end{array}$ \\
\hline $\begin{array}{l}\text { Projeto Big Riso de } \\
\text { Responsabilidade Social }\end{array}$ & 2006 & $\begin{array}{l}\text { M.Bigucci } \\
\text { Ltda. }\end{array}$ & $\begin{array}{l}\text { Projeto de voluntariado para minimização dos fatores } \\
\text { emocionais e psicológicos de crianças com câncer durante sua } \\
\text { internação e tratamento. }\end{array}$ \\
\hline $\begin{array}{l}\text { Programa de } \\
\text { Requalificação de Mão- } \\
\text { de-obra }\end{array}$ & 2007 & $\begin{array}{l}\text { Sinduscon - } \\
\text { MG }\end{array}$ & $\begin{array}{c}\text { Seu objetivo é formar, qualificar e aperfeiçoar os trabalhadores - } \\
\text { pedreiros de acabamento e alvenaria, bombeiros e eletricistas - } \\
\text { de construtoras associadas ao } \\
\text { sindicato, visando fortalecer e estimular o desenvolvimento de } \\
\text { ações sociais no setor. }\end{array}$ \\
\hline Projeto Construir & 2007 & $\begin{array}{l}\text { Sinduscon - } \\
\text { PA }\end{array}$ & $\begin{array}{l}\text { O projeto visa capacitar os trabalhadores desempregados e } \\
\text { autônomos; conceder cidadania aos trabalhadores } \\
\text { analfabetos; dar oportunidade aos trabalhadores } \\
\text { desempregados e solidariedade às crianças } \\
\text { portadoras de necessidades especiais. }\end{array}$ \\
\hline Projeto Cosme e Damião & 2007 & Cofix Ltda. & $\begin{array}{c}\text { O projeto é destinado à qualificação dos trabalhadores da } \\
\text { empresa - carpinteiro de fôrmas. A adesão dos colaboradores é } \\
\text { voluntária. }\end{array}$ \\
\hline
\end{tabular}


Empresas e entidades de classe do setor construção civil e do mercado imobiliário podem participar do concurso, e um dos critérios que dá credibilidade ao prêmio é que os projetos inscritos devem ter ao menos um ano de operacionalização.

A tabela 2 descreve os principais projetos premiados nas edições de 2005 e 2006 do Prêmio CBIC.

Reforça-se que as ações de responsabilidade social promovidas no setor ainda possuem um caráter muito assistencialista, e que poderão evoluir a partir do momento em que os dirigentes das empresas estiverem conscientizados do escopo e abrangência do tema, podendo dessa maneira investir em ações em outras frentes de trabalho possíveis, alcançando outras partes interessadas e alinhando-se mais ao negócio da empresa.

\subsection{Responsabilidade social e cadeia de fornecedores na construção de edifícios}

No setor da construção civil, não existe uma liderança forte que organize a cadeia como um todo, pois, próximas do cliente final, as construtoras dividem com empreendedores e projetistas a concepção e produção do produto (construção). Além disso, milhares de empresas, em sua maioria pequenas e médias, atuam nãos empreendimentos de construção, e exercem pouca influência nas empresas fabricantes de materiais, algumas das quais de maior poder comercial e tecnológico. Esta característica faz com que a coordenação da cadeia de fornecedores seja mais complexa no setor da construção, que em outros setores (FONTANINI; PICCHI, 2003).

Esse cenário exige das incorporadoras e construtoras um esforço ainda maior para alavancar consigo seus fornecedores. Haguenaurer et al. (2001) cita que, mesmo a indústria da construção tendo aumentado sua participação e sua produção nos últimos anos ao de sua pesquisa, não conseguiram alavancar expansão similar em seus fornecedores, o que, segundo Blanco (2007) gerou instabilidade no atendimento da demanda de crescimento do mercado imobiliário no ano de 2007. 
Um dos grandes desafios das incorporadoras e construtoras é, assim, o planejamento em longo prazo e a coordenação de suas ações com seus fornecedores, alinhando estrategicamente as empresas da cadeia de suprimentos com suas perspectivas (FURTADO, 2005), fazendo com que as demandas sejam atendidas. Isso se torna mais crítico nesse momento de crescimento em que já se sinaliza a possível falta de determinados recursos para abastecer o mercado. Segundo Blanco (2007), o aumento do número de empreendimentos exige um planejamento cada vez mais apurado por parte das construtoras, para fidelizar os fornecedores e as locadoras de equipamentos e garantir o abastecimento. Além disso, também é importante estudar a possibilidade de substituição de alguns materiais e equipamentos no caso de escassez.

Outro fator que evidencia a necessidade dessa melhor integração com os fornecedores da cadeia está relacionado à qualidade final dos produtos ofertados, pois sem a contribuição dos fornecedores de materiais e serviços, as incorporadoras e construtoras têm que fazer um grande esforço para suprir essa deficiência de qualidade e nem sempre conseguem atingir as expectativas de seus clientes. Nesse sentido, a implantação dos Sistemas de Gestão da Qualidade nas empresas construtoras trouxe consigo uma reflexão sobre suas relações com fornecedores, evidenciando a importância desses agentes para a obtenção da qualidade no processo construtivo (REIS; MELHADO,1998).

Segundo Martins (2003), as empresas fornecedoras devem conduzir o processo de desenvolvimento de novos produtos partindo de uma estratégia que considere fatores como o desempenho da inovação inserida no edifício, contribuindo dessa forma para a qualidade global do empreendimento. Têm também o papel de compreender as dificuldades enfrentadas pelas empresas construtoras na implantação das novas tecnologias para estabelecer novas relações com essas empresas.

A necessidade das incorporadoras e construtoras investirem cada vez mais em sua cadeia de fornecedores é reforçada por Furtado (2005), que afirma que as empresas têm dedicado cada vez mais seus recursos internos para melhoria de suas competências, gerando um conseqüente interesse pela terceirização de atividades. 
Porém não basta terceirizar as atividades, é necessário saber contratá-las, controlálas e avaliá-las.

São vários os aspectos a serem abordados na sistemática de avaliação dos fornecedores, e que segundo Jobim et al. (2002) podem ser divididos nos seguintes grupos: aspectos técnicos, aspectos ambientais, aspectos de mercado e aspectos sociais e legais. Cada um desses aspectos propõe uma série de critérios a serem avaliados junto aos fornecedores, a fim de garantir às empresas contratantes um resultado final mais satisfatório, conforme ilustrado na figura 6.

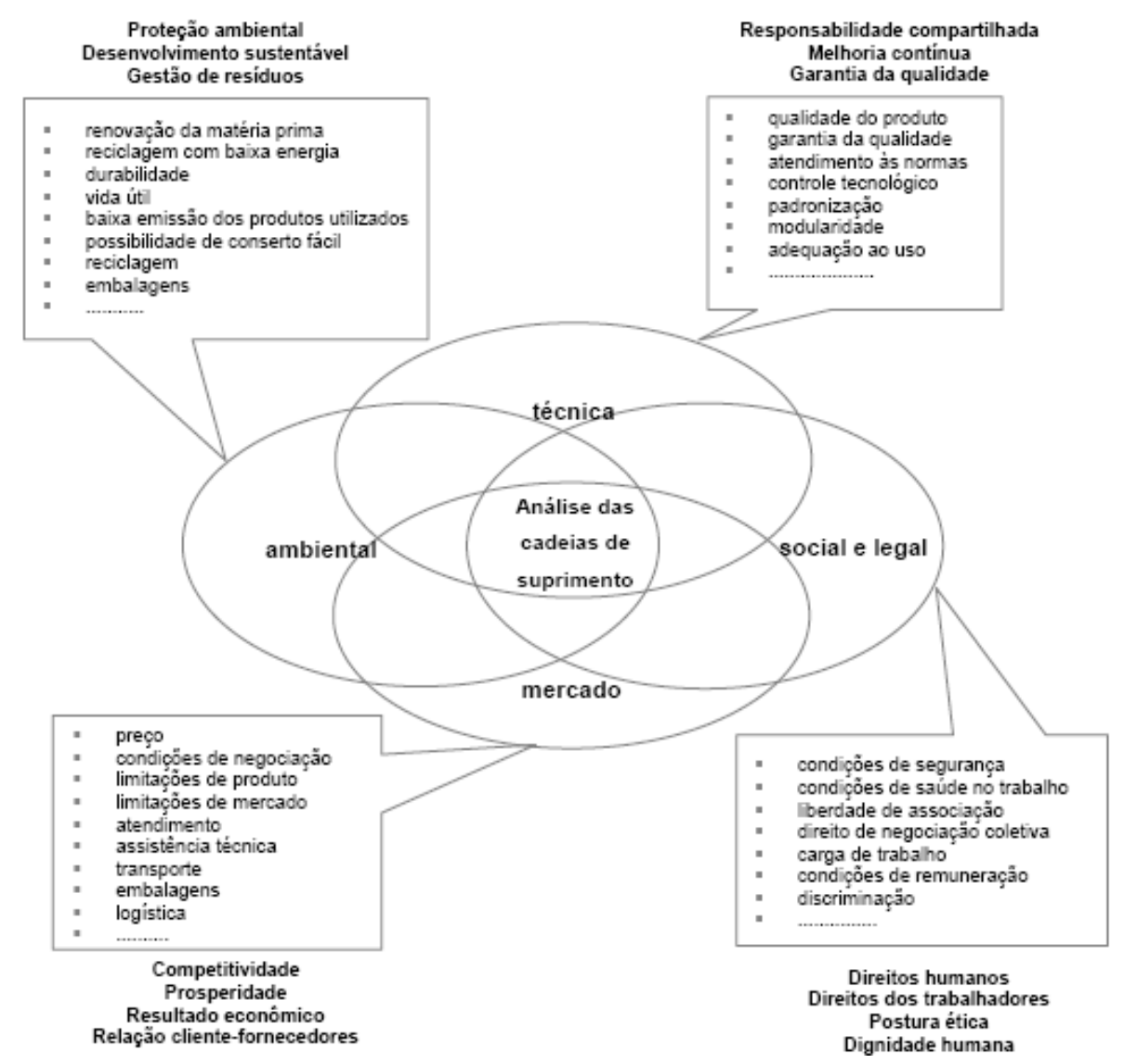

Figura 6 - Aspectos considerados no modelo proposto para a análise dos agentes da cadeia de suprimentos (JOBIM et. al., 2002)

Porém, em função do grande número de fornecedores das incorporadoras e construtoras, é muito difícil tratar todos os aspectos propostos por Jobim et al. (2002). Segundo Sterzi et al. (2006), incluir todos os membros da cadeia de fornecedores pode ser uma tarefa muito difícil e a estrutura pode tornar-se muito 
complexa. Torna-se apropriado estabelecer critérios para a classificação dos integrantes da cadeia.

Solano e Heineck (1996) propõem que os fornecedores mais impactantes das empresas sejam selecionados pela utilização da curva $A B C$, onde os insumos mais representativos, tanto de materiais quanto de serviços, são identificados e as diversas áreas da empresa atuam na garantia de um bom relacionamento. A área de planejamento, em conjunto com suprimentos, estabelece uma política de relacionamento por meio de cadastramento, avaliação da capacidade de produção, capacidade de manutenção de preços, entrega nos prazos, capacidade de parcerias e avaliação de desempenho, política de compras em pacotes antecipados e cronogramas de entregas. Com o departamento de recursos humanos, estabelece política de contratação e treinamentos, incentivos e avaliação de mão-de-obra, política de investimento, sistema de controle de variáveis, etc.

Ainda na escolha dos fornecedores mais impactantes de incorporadoras e construtoras, devem-se considerar também as atividades que dão suporte ao processo de produção, nas quais, segundo Cardoso et al. (1998), estão inseridas os projetos de produto, orçamentos, planejamento e gerenciamento, estudos de preparação e desenvolvimento de métodos construtivos, projetos para produção e engenharia de segurança.

A questão da inclusão de critérios de sustentabilidade na seleção de fornecedores já aparece no setor. Por exemplo, a metodologia AQUA de certificação ambiental de empreendimentos (FCAV, 2007) tem como um dos critérios para avaliar se um empreendimento pode ou não ser considerado de elevada qualidade ambiental o fato de o empreendedor exigir que se escolham fabricantes de produtos que não pratiquem a informalidade fiscal e trabalhista.

Além disso, deve ser considerada ainda a complexidade do mercado de fornecimento de materiais e serviços. A matriz de Kraljic (GUILHERME, 2007), ilustrada na figura 7 , propõe a classificação dos materiais e serviços em quatro quadrantes a fim de identificar os impactos dos mesmos sobre o resultado financeiro dos negócios e também o risco de oferta.

\begin{tabular}{|c|c|c|}
\hline-0 & Produtos de alavancagem & Produtos estratégicos \\
\hline
\end{tabular}




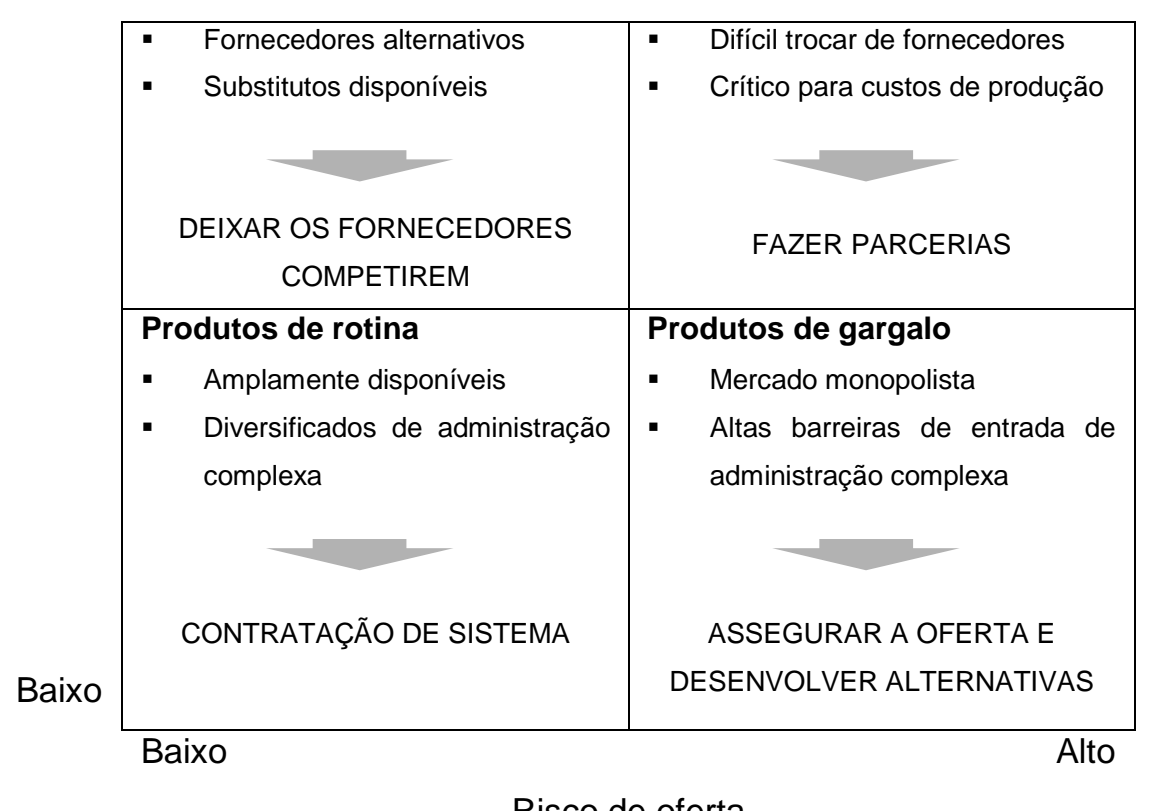

Risco de oferta

Figura 7 - Matriz de Kraljic (GUILHERME, 2007)

Estabelecidos os principais fornecedores com os quais a empresa incorporadora e construtora irá trabalhar, ou seja, os mais impactantes, é necessária a definição de uma política a ser utilizada, para que a empresa como um todo tenha um padrão estabelecido para tomada de decisão. Segundo Isatto (2006), é importante que os princípios da estratégia a ser utilizada sejam traduzidos nas decisões relacionadas com os fornecedores que se apresentem no quotidiano da empresa. Este é o principal papel a ser desempenhado pela política de fornecedores, buscando estabelecer um padrão esperado de comportamento frente aos fornecedores, por meio de uma linguagem única e estável na empresa com relação aos mesmos.

Em um contexto onde a cooperação dos fornecedores é aspecto fundamental para o sucesso da empresa, a formulação da política de fornecedores não pode se limitar a mostrar o que a empresa deseja por parte dos mesmos, mas também os benefícios com os quais ela pretende acenar para obter a sua cooperação, além de estabelecer mecanismos responsáveis por operacionalizar tais recompensas (ISATTO, 2006).

A política de fornecedores pode ser composta por uma série de princípios, diretrizes e procedimentos, considerando inclusive as questões éticas e de responsabilidade social, por meio de códigos de conduta por exemplo.

Isatto (2006) sugere um modelo para política de fornecedores composto por quatro tipos de elementos: princípios, diretrizes, mecanismos e procedimentos. Os 
princípios são de orientação geral e não tratam de problemas ou situações concretas, apenas visam conduzir a tomada de decisão em situações novas ou não previstas. As diretrizes são regras de conduta e servem como orientação. Os procedimentos são processos gerenciais da empresa e os mecanismos servem para ligar as diretrizes aos processos gerenciais da empresa, conforme figura 8.

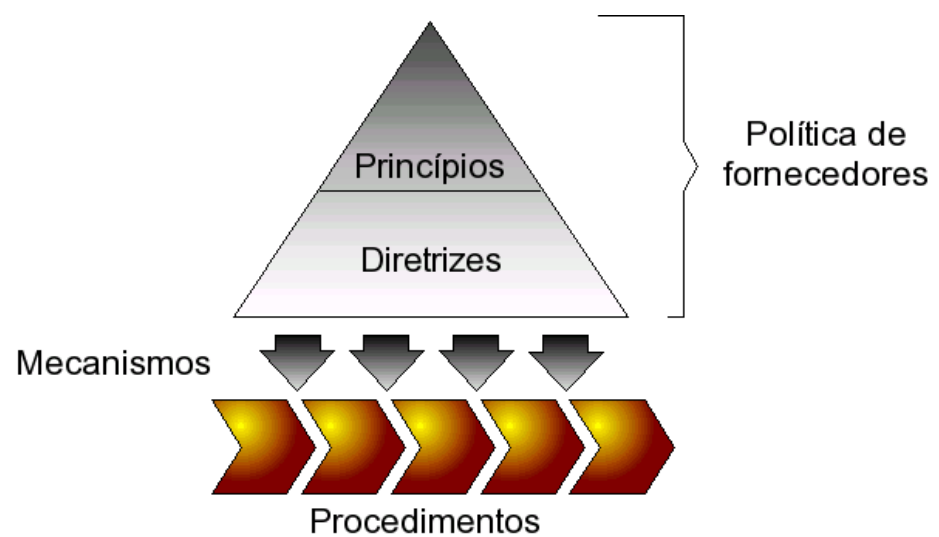

Figura 8 - Modelo geral empregado na formulação da política de fornecedores (ISATTO, 2006)

Souza et al. (1998) apresentam ainda outras atividades nas quais construtora e o fornecedor possuem obrigações definidas para o bom andamento de suas relações de negócios, conforme a tabela 3.

Tabela 3 - Resumo das obrigações e deveres da empresa promotora-construtora e do fornecedor (SOUZA et al., 1998)

\begin{tabular}{|c|c|}
\hline EMPRESA & FORNECEDOR \\
\hline $\begin{array}{c}\text { Estabelecer critérios para especificações de } \\
\text { materiais } \\
\text { Qualificar os fornecedores } \\
\text { Controlar os documentos de compra e recepção } \\
\text { Controlar a qualidade do material recebido } \\
\text { Viabilizar recursos para realizações de medições e } \\
\text { ensaios } \\
\text { Controlar o manuseio e armazenamento dos insumos } \\
\text { Reduzir o número de fornecedores } \\
\text { Estabelecer relacionamentos de longo prazo com os } \\
\quad \text { fornecedores } \\
\text { Realizar investimentos da área de P\&D, juntamente } \\
\text { com o fabricante; } \\
\text { Retroalimentar o fabricante sobre o desempenho dos } \\
\text { insumos fornecidos }\end{array}$ & $\begin{array}{c}\text { Apoiar os projetistas } \\
\text { Fornecer informações relativas ao consumo dos } \\
\text { insumos } \\
\text { Fornecer produtos com características físicas e de } \\
\text { desempenho, conforme anunciadas } \\
\text { Respeitar prazo de entrega, possibilitando um real } \\
\text { planejamento da obra } \\
\text { Informar a obra sobre os cuidados com relação ao } \\
\text { estoque e manuseio dos insumos } \\
\text { Buscar certificação } \\
\text { Manter um rápido atendimento apresentando } \\
\text { soluções eficientes } \\
\text { Realização de investimentos nas áreas de P\&D, } \\
\text { juntamente com a construtora } \\
\text { Busca de melhoria contínua, a partir das informações } \\
\text { retroalimentadas pela construtora }\end{array}$ \\
\hline
\end{tabular}

$\mathrm{Na}$ cadeia produtiva da construção civil, as relações com fornecedores podem ser muito diferentes, pois são empresas de portes e atividades diversas, com maior ou menor poder de influência por parte das construtoras. 
No caso dos fornecedores de insumos, existem dois grupos bem distintos: o de materiais artesanais e de baixa qualidade, produzidos de maneira pulverizada e sem grandes barreiras de entrada no mercado; e o de produtos com produção oligopolizada, onde as grandes indústrias ditam os preços. Já para os fornecedores de serviços especializados e mão-de-obra, os serviços executados são aqueles que ao longo do tempo foram terceirizados das construtoras para buscar-se melhores resultados, como a redução de custos, conseguindo, por exemplo, com o aumento da produtividade. Já o setor de projetos é bastante fragmentado, sendo constituído em grande parte por profissionais autônomos independentes, o que justifica o baixo poder de barganha dos fornecedores de projetos em relação aos seus principais clientes, as empresas de construção civil. (MEIRA; QUINTELLA, 2004). Porém, segundo Kraljic (GUILHERME, 2007), a classificação dos fornecedores pode ser feita de forma mais detalhada, fazendo com que os fornecedores, sendo eles de materiais ou serviços, sejam analisados sob a ótica de riscos ao negócio, e não apenas por suas características setoriais.

A grande variação existente entre os portes das empresas fornecedoras da construção civil, a influência delas sobre 0 resultado financeiro dos empreendimentos e também o poder que as incorporadoras e construtoras têm sobre elas influenciam o relacionamento entre cliente e fornecedor.

Outro fator que pode ainda influenciar a relação entre construtoras e fornecedores é - modelo de gestão adotado para a aquisição dos insumos e contratação de serviços: de forma geral, sendo centralizada, consegue-se uma melhor condição de negociação, diferentemente da condição de uma única obra negociando com um fornecedor. Mas deve-se ainda nessa situação considerar o perfil do fornecedor e sua influência nos resultados do negócio, pois a condição de negociação financeira não é o único fator predominante na escolha do modelo de contratação.

Com base nas relações atuais entre incorporadoras, construtoras e os fornecedores da cadeia produtiva da construção civil, as ações de melhoria no relacionamento com os fornecedores, a redução de conflitos e o investimento no crescimento e amadurecimento das parcerias com base nos conceitos de responsabilidade social poderiam ser implementadas mais facilmente nas empresas de menor porte em 
função de um acesso mais fácil e a influência positiva traria maiores e melhores resultados.

A política de fornecedores sempre será necessária, independente de estar pautada nos conceitos de responsabilidade social ou não, já que diversos problemas da cadeia ainda precisam ser resolvidos. Há anos, questões como a qualidade dos serviços e dos projetos e o impacto destes no processo de produção não vêm sendo devidamente considerados, como também a ausência de coordenação entre os diversos projetos e serviços de engenharia, bem com a baixa integração destes com os sistemas de produção das construtoras na estão devidamente solucionados (Cardoso et. al., 1998).

O investimento em responsabilidade social pode trazer benefícios quanto à melhoria no relacionamento e na postura ética entre incorporadoras, construtoras e fornecedores, e, conseqüentemente, solucionar questões de responsabilidades e definições dos papéis de cada um dos intervenientes. Cabe às incorporadoras e às construtoras definirem seu interesse em investir nessa sua parte interessada, destinando recursos e ferramentas que tragam resultados positivos. Como visto no item 2.2, são praticamente nulas as ações atuais de responsabilidade social voltadas aos fornecedores, talvez em virtude da complexidade na criação de políticas de responsabilidade social, como também na suas aplicações no cotidiano da empresa contratante e também na avaliação e monitoramento da eficácia dessas ações, que são difíceis de serem mensuradas quantitativamente. 


\section{O PROGRAMA TEAR}

O acompanhamento do Programa Tear visa o entendimento da metodologia por ele adotada e também é a base para a análise de sua implementação no setor de incorporação da construção civil. Visa ainda a análise das dificuldades das empresas fornecedoras de pequeno e médio porte do setor da construção civil em implantar essa metodologia e os impactos causados pela sua participação no programa. Com base na experiência do Programa Tear, serão propostas diretrizes às incorporadoras e construtoras para implementarem ações de responsabilidade social junto aos seus fornecedores de pequeno e médio porte.

Nesse capítulo, são descritas as características do Programa Tear e sua metodologia. No capítulo 4 é feita uma descrição da sua implementação, com base no acompanhamento mensal das reuniões promovidas ao longo do programa. No capítulo 5 é apresentada uma análise da dinâmica do programa e de seus resultados obtidos junto às empresas estudadas.

\subsection{1 que é o Programa Tear}

O Programa Tear é um projeto desenvolvido pelo Instituto Ethos de Responsabilidade Social Empresarial, com investimento do Fundo Multilateral de Investimentos (Fumin) do Banco Interamericano de Desenvolvimento (BID).

O Banco Interamericano de Desenvolvimento é uma instituição financeira que atua com programas de empréstimos e cooperação técnica para projetos de desenvolvimento econômico e social. É a principal fonte de financiamento multilateral para projetos de desenvolvimento econômico, social e institucional, bem como programas de promoção do comércio e integração regional na América Latina e no Caribe.

O Programa Tear procura aumentar a competitividade e a sustentabilidade de pequenas e médias empresas, ampliando suas oportunidades de negócio por meio da adoção de práticas de responsabilidade social empresarial aprendidas ao longo 
do mesmo. O programa considera que tais empresas trabalham como fornecedoras de empresas maiores. Ao participarem do Programa Tear, todas as empresas contratantes e fornecedoras - comprometem-se a trabalhar praticando uma gestão socialmente responsável nos processos internos e no relacionamento com suas partes interessadas.

Para o desenvolvimento do Programa, foram inicialmente identificados sete setores da economia:

- Açúcar e álcool;

- Construção Civil;

- Energia Elétrica;

- Mineração;

- Petróleo e Gás;

- Siderurgia;

- Varejo.

Dentro de cada setor, identificou-se primeiramente uma grande empresa que se destacasse por suas práticas de responsabilidade social empresarial, que foi definida como a "âncora" do projeto no setor. No caso do setor da construção civil, foram criados dois grupos de trabalho: um para incorporação de edificações, onde foram escolhidas duas empresas âncoras (única exceção do programa), Gafisa S.A. e Y.Takaoka Empreendimentos S.A., e outro para grandes obras de construção pesada, onde a âncora é a Construções e Comércio Camargo Corrêa.

Cada uma das empresas-âncoras teve o papel de identificar, entre seus fornecedores e clientes, 15 empresas com as quais o Programa Tear pudesse ser desenvolvido. Dessa forma, âncora e fornecedores/clientes se comprometeram a trabalhar a incorporação de ações de responsabilidade social em suas práticas.

Além das empresas-âncoras, o programa ainda definiu parceiros setoriais nomeados agentes de indução ou indutores de comportamento, para disseminação da metodologia para outras empresas e cadeias de valor. No caso da construção civil, o 
agente de indução é o Sindicato da Habitação (Secovi) para o subsetor incorporação.

A tabela 4 traz as empresas e as entidades participantes do Programa Tear.

Tabela 4 - Empresas e entidades participantes do Programa Tear (ETHOS, 2007)

\begin{tabular}{|c|c|c|}
\hline SETOR & EMPRESA ȦNCORA & ENTIDADES PARCEIRAS \\
\hline Açúcar e Álcool & $\begin{array}{l}\text { Companhia Açucareira } \\
\text { Vale do Rosário }\end{array}$ & União da Agroindústria Canavieira de São Paulo (Unica) \\
\hline $\begin{array}{l}\text { Construção Civil - } \\
\text { Grandes Obras }\end{array}$ & Camargo Corrêa & Não há \\
\hline $\begin{array}{l}\text { Construção Civil - } \\
\text { Incorporação }\end{array}$ & Y. Takaoka e Gafisa & Sindicato da Habitação (Secovi) \\
\hline Energia Elétrica & CPFL Energia & Associação Brasileira dos Distribuidores de Energia Elétrica (Abradee) \\
\hline Mineração & $\begin{array}{l}\text { Companhia Vale do Rio } \\
\text { Doce }\end{array}$ & $\begin{array}{c}\text { Federação das Indústrias do Estado de Minas Gerais (Fiemg) e Instituto } \\
\text { Brasileiro de Mineração (Ibram) }\end{array}$ \\
\hline Petróleo e Gás & Petrobrás & Instituto Brasileiro de Petróleo (IBP) \\
\hline Siderurgia & ArcelorMittal & Federação das Indústrias do Estado de Minas Gerais (Fiemg) \\
\hline Varejo & Extra Hipermercados & Não há \\
\hline Todos & - & $\begin{array}{c}\text { Associação Brasileira das Entidades Fechadas de Previdência } \\
\text { Complementar (Abrapp) e Serviço Brasileiro de Apoio às Micro e } \\
\text { Pequenas Empresas (Sebrae) }\end{array}$ \\
\hline
\end{tabular}

\subsection{Vantagens esperadas para as pequenas e médias empresas participantes do Programa Tear}

O Programa Tear visa aumentar a competitividade empresarial por meio da capacitação e adoção de práticas de responsabilidade social. Pretende oferecer às pequenas e médias empresas, de modo a atingir um desenvolvimento sustentado: 0 desenvolvimento de melhores vínculos comerciais, com relações mais justas e duradouras; um relacionamento mais próximo com outros agentes do setor; a troca de experiências por meio da rede formada com as demais pequenas e médias empresas; a aquisição de conhecimento por meio dos grupos de trabalho e de publicações.

As pequenas e médias empresas participantes do programa ainda podem contar com uma consultoria de sessenta e quatro horas promovida pelo Instituto Ethos ao longo do período do Programa Tear, consultoria essa que auxilia na implementação das ferramentas e conceitos no negócio de cada uma delas. 


\subsection{Principais resultados esperados}

Segundo estimativas do Instituto Ethos, ao final do Programa Tear, espera-se que as empresas participantes de todos os setores possam atingir os resultados abaixo:

- maior incorporação da sustentabilidade em sua gestão;

- acesso a novos mercados e desenvolvimento de novos produtos e serviços;

- aprofundamento e melhoria das relações comerciais com os parceiros envolvidos;

- identificação de oportunidades de desenvolvimento de novos produtos e serviços;

- redução de custos;

- aumento de receita;

- ganhos de competitividade e produtividade;

- documentação e multiplicação das melhores práticas;

- modelo e referência para o desenvolvimento do programa no seu segmento de atuação;

- visibilidade/projeção nacional e internacional;

- contribuição para o desenvolvimento local sustentável e para a sustentabilidade do país.

\subsection{Metodologia e ferramentas utilizadas no programa}

A Metodologia Tear foi criada em parceria com a consultoria BSD $^{8}$, levando-se em consideração a experiência de seis grandes empresas que já trabalham com a implementação da responsabilidade social empresarial em sua cadeia de fornecedores. São elas: Banco Real ABN Amro, Belgo, O Boticário, CPFL, Federação das Indústrias do Estado da Bahia (Fieb) e Natura.

\footnotetext{
8 A BSD é uma consultoria para soluções na área de gestão. Disponível em <www.bsdnet.com/bsd_brasil>.
} 
A construção da Metodologia Tear levou em consideração as lições aprendidas de cada uma dessas experiências, compilando fatores críticos de sucesso para uma implementação efetiva do tema. Ela se divide em cinco grandes fases, tendo como premissa o trabalho em rede e a incorporação na gestão da empresa dos mecanismos e produtos desenvolvidos.

As empresas âncoras, as empresas fornecedoras escolhidas pelas âncoras para compor o grupo e os representantes do Instituto Ethos (coordenadora das reuniões, coordenadora geral do programa e consultora local) reúnem-se uma vez ao mês para o desenvolvimento e implementação da metodologia. As reuniões duram o dia todo. As empresas âncoras são responsáveis por convocar os participantes para as reuniões e oferecer o local de realização das mesmas, promovendo todos os recursos necessários (alimentação e estacionamento dos participantes, recursos audiovisuais, etc.).

A metodologia de implementação do Programa Tear é dividida em sete etapas (nomeadas de $\mathrm{A}$ a $\mathrm{G}$ ) e é desenvolvida ao longo das reuniões mensais, conforme mostra a tabela 5 .

$\mathrm{Na}$ etapa A acontece o início da construção da rede formada na cadeia produtiva do setor e a sensibilização das empresas participantes. Na etapa B, é dado continuidade ao processo de sensibilização e é feita a análise do negócio de cada empresa participante com foco na sustentabilidade. A etapa $C$ é composta pelo diagnóstico da gestão sustentável, a ser feita por meio de ferramentas como os Indicadores Ethos de Responsabilidade Social (ETHOS, 2007). Na etapa D, após o diagnóstico, as empresas participantes do programa criam um plano de ação para atender aos novos requisitos sustentáveis. $A$ etapa $E$ consiste na comunicação dessas ações por meio da elaboração de um balanço social. A etapa $F$, que deve permear por todo o programa, consiste no fortalecimento das relações entre as empresas participantes. E, finalmente, a etapa $G$ consiste na expansão da rede após a conclusão do programa, onde empresas participantes se tornam âncoras de outras, disseminando os conceitos e ações de responsabilidade social. 
Tabela 5 - Quadro resumo da metodologia do Programa Tear
A. INÍCIO DA CONSTRUÇÃO DA REDE E SENSIBILIZAÇÃO
A1. Definir o modelo do programa
A2. Formalizar o compromisso com o programa
A3. Comprometer a equipe executora
A4. Selecionar as empresas participantes (clientes e/ou fornecedores)
A5. Formalizar o compromisso da rede com o programa
A6. Sensibilizar a cadeia de valor

B. SENSIBILIZAÇÃO E ANÁLISE DA SUSTENTABILIDADE DO NEGÓCIO

B1. Estabelecer compromissos e princípios de trabalho no grupo

B2. Sensibilizar para a sustentabilidade

B3. Analisar o negócio sob a ótica da sustentabilidade

B4. Mapear as partes interessadas

B5. Identificar o estágio de desenvolvimento em gestão sustentável

C. DIAGNÓSTICO DA GESTÃO SUSTENTÁVEL

C1. Aplicar os Indicadores Ethos

C2. Efetuar análise qualitativa das práticas de RSE na empresa

D. PLANOS DE AÇÃO

D1. Priorizar metas

D2. Correlacionar metas com fatores críticos do negócio

D3. Analisar o estudo da sustentabilidade da cadeia e do setor

D4. Elaborar planos de ação

D5. Implementar e monitorar planos de ação

E. COMUNICAÇÃO E RELATÓRIO

E1. Elaborar o Balanço Social

E2. Validar Balanço Social

F. CONSOLIDAÇÃO DA REDE (CONSTANTE)

F1. Fortalecer as relações entre os participantes da rede

F2. Incorporar práticas do programa na gestão

G. EXPANSÃO DA REDE

G1. Aplicar a metodologia Tear em novos grupos

No capítulo 4, são apresentados exemplos práticos de cada uma das etapas do programa vivenciadas ao longo do estudo de caso realizado. Segue a descrição das etapas do programa.

\section{A. INÍCIO DA CONSTRUÇÃO DA REDE E SENSIBILIZAÇÃO}

\section{A1. Definir o modelo do programa}

A definição do modelo do programa a ser utilizado fica a critério do indutor da rede, ou seja, do promotor do programa 9 .

\footnotetext{
${ }^{9}$ Em função da experiência acompanhada ter sido a primeira utilização do programa, o indutor da rede neste caso foi o Instituto Ethos (o Instituto Ethos também continuou sendo o indutor para as demais fases do programa). No caso de novas edições do programa, o promotor do mesmo será o indutor da rede, aquele que toma a iniciativa de realizar o programa.
} 
O programa deve focar o aprofundamento e a incorporação da responsabilidade social empresarial na cadeia de valor participante, considerando suas características específicas. Em edições posteriores, as experiências obtidas pelos programas piloto devem ser consideradas.

\section{A2. Formalizar o compromisso com o programa}

O indutor do programa formaliza com a empresa âncora escolhida o compromisso formal de participação. Nesse momento, todas as responsabilidades, recursos necessários e continuidade da participação no programa são apresentados, para que a âncora avalie e aceite o convite, por meio de um documento assinado pela diretoria da empresa.

Nesse processo, são apresentados os resultados e benefícios esperados do programa, que poderão potencializar o negócio da empresa âncora envolvida.

\section{A3. Comprometer a equipe executora}

O indutor solicita à empresa âncora a definição da equipe responsável na empresa que será responsável pelo programa. Nesse momento, são comunicadas todas as responsabilidades da empresa âncora com o programa, para que a equipe executora tenha ciência de suas tarefas ao longo do mesmo, que tem previsão de duração de 36 meses.

\section{A4. Selecionar as empresas participantes (clientes e/ou fornecedores)}

O indutor solicita que a empresa âncora selecione as empresas participantes do programa, podendo para isso envolver outras áreas da empresa além da equipe executora previamente definida, como as áreas de suprimentos e atendimento ao cliente por exemplo. Na metodologia atual, foi solicitado às âncoras que listassem 18 empresas de sua cadeia de clientes/fornecedores para compor o grupo de trabalho.

\section{A5. Formalizar o compromisso da rede com o programa}

A empresa âncora formaliza o convite às empresas que listou para participarem do programa, compondo a rede. É necessária a elaboração de um documento formal assinado por um representante da empresa convidada. 
A âncora deve evidenciar a importância do programa para as empresas convidadas e passar a elas uma visão detalhada do programa.

\section{A6. Sensibilizar os agentes da cadeia de valor}

O grupo de trabalho formado por empresa âncora e demais empresas participantes deve divulgar publicamente seu compromisso e incentivar outras empresas da cadeia de valor a conhecer os conceitos da responsabilidade social empresarial.

Essa divulgação pode ser feita por meio de Internet, releases para imprensa, e-mail, etc.

\section{B. SENSIBILIZAÇÃO E ANÁLISE DA SUSTENTABILIDADE DO NEGÓCIO}

\section{B1. Estabelecer compromissos e princípios de trabalho no grupo}

Nesse momento, as empresas participantes do grupo de trabalho formado (âncora e empresas convidadas) passam a se encontrar periodicamente para as reuniões de trabalho. Nesse primeiro momento, são estabelecidos os compromissos e princípios que orientarão o trabalho em rede, por meio de um roteiro de perguntas sobre o participante, os compromissos e princípios acordados para o grupo e o capital humano existente no grupo.

Com essas informações, o grupo define quais os compromissos assumidos e os princípios estabelecidos a serem seguidos ao longo das reuniões do Programa Tear.

\section{B2. Sensibilizar para a sustentabilidade}

O objetivo principal dessa etapa é conscientizar as empresas participantes sobre a relevância da adoção dos conceitos da sustentabilidade na gestão do negócio. A idéia é mobilizar as empresas e motivá-las para uma mudança cultural na gestão da empresa.

Filmes e jogos ligados ao tema são utilizados para melhor compreensão do assunto. Outras dinâmicas utilizadas são a identificação de onde a empresa está e aonde quer chegar, e apresentação de empresas que incluíram em seu planejamento, missão, visão e valores os conceitos de sustentabilidade. 


\section{B3. Analisar o negócio sob a ótica da sustentabilidade}

As empresas são convidadas a analisarem seu negócio sob a ótica da sustentabilidade, usando para isso a matriz "SWOT" (Forças e Fraquezas, Oportunidades e Ameaças). Terão como resultado um mapa estratégico da empresa sob a ótica da sustentabilidade.

A matriz "SWOT", ou matriz "FOFA", é uma ferramenta de análise onde são identificadas as forças e fraquezas (aspectos internos), oportunidades e ameaças (aspectos externos) que agem sobre um determinado negócio.

\section{B4. Mapear as partes interessadas}

Nesta etapa, as empresas participantes devem identificar e conhecer as partes interessadas impactadas pelo seu negócio e devem avaliar quais impactos sua empresa pode provocar em cada uma delas.

Para o mapeamento das partes interessadas, a empresa deve analisar a amplitude do impacto do negócio e, para cada uma das partes interessadas identificadas, elencar os riscos, oportunidades, impactos da empresa sobre essa parte interessada, compromisso da empresa com a mesma e formas de diálogos existentes.

\section{B5. Identificar o estágio de desenvolvimento em gestão sustentável}

Para esta etapa, a metodologia recomenda a utilização do referencial normativo da Accountability (ACCOUNTABILITY, 1999) para identificação do estágio de desenvolvimento que a empresa se encontra quanto à gestão sustentável.

\section{DIAGNÓSTICO DA GESTÃO SUSTENTÁVEL}

\section{C1. Aplicar os Indicadores Ethos}

As empresas participantes devem nesse momento da metodologia aplicar os Indicadores Ethos de Responsabilidade Social, para realizar seu diagnóstico em relação a responsabilidade social e avaliar seu estágio de desenvolvimento. 
Os Indicadores Ethos de Responsabilidade Social são uma ferramenta utilizada para identificar como a empresa se encontra em relação às ações de responsabilidade social empresarial.

São compostos por quarenta indicadores, divididos em sete temas: valores, transparência e governança; público interno; meio ambiente; fornecedores; consumidores e clientes; comunidade; governo e sociedade.

Para cada um dos indicadores, existe a seguinte estrutura: indicadores de profundidade, indicadores qualitativos e indicadores quantitativos (para alguns casos). Os indicadores de profundidade são compostos de quatro estágios, onde a empresa, ao responder, deve se enquadrar em um dos estágios apresentados com base na sua realidade no momento. A empresa ainda tem as alternativas de responder que não havia tratado antes do assunto ou ainda que não vê aplicabilidade do assunto ao cenário de sua empresa (porém, essa resposta deve ser justificada). Os indicadores qualitativos são compostos por questões binárias (sim ou não), que servem para justificar o estágio escolhido no indicador de profundidade. Já os indicadores quantitativos, que não existem para todos os indicadores, servem para criar um histórico da empresa ao comparar os dados de anos anteriores, para realmente justificar a promoção de ações de mudança.

Existe ainda a opção das empresas responderem aos Indicadores Ethos de Responsabilidade Social Ethos-Sebrae, que são uma versão direcionada às micro e pequenas empresas. A estrutura do questionário é dividida em 36 indicadores, dentro dos mesmos sete temas.

Guardando forte semelhança com o mecanismo anterior, para cada um dos indicadores, existe a seguinte estrutura: perguntas-chave, perguntas binárias, perguntas quantitativas e espaço para anotações de planejamento. As perguntaschave propõem uma reflexão sobre o nível em que a empresa se encontra sobre determinado assunto, respondendo às perguntas com as alternativas "não“, "em parte“, "em grande parte", "sim" ou "não vemos aplicação disso em nossa empresa". As perguntas binárias servem para justificar a resposta escolhida para as perguntaschaves. Já as perguntas quantitativas servem para criar um histórico da empresa ao comparar os dados de anos anteriores, para realmente justificar a promoção de 
ações de mudança. O espaço para anotações de planejamento é um espaço reservado para que a empresa registre as ações que serão tomadas nas seguintes etapas: imediatamente, após algum planejamento, após obter informações ou ainda não nesse momento, porque não se acredita que algo possa ser feito.

Ambas as ferramentas permitem que a empresa, após responder o respectivo questionário, receba um diagnóstico de como está seu desempenho quanto a Responsabilidade Social Empresarial. O resultado é apresentado da seguinte forma: o Instituto Ethos apresenta a nota da empresa, e faz um comparativo dessa nota com as empresas benchmarking do mercado (ou seja, com as melhores ações apresentadas nas respostas aos indicadores) e também com todas as empresas que responderem os indicadores no período de referência. As empresas benchmarking são identificadas com base nas respostas dos indicadores: quando aparecem respostas com desempenho superior à média, o Instituto Ethos contata a empresa para identificar quais ações geraram aquela resposta aos Indicadores.

\section{C2. Efetuar análise qualitativa das práticas de RSE na empresa}

As empresas, após receberem a sua avaliação resultante das respostas aos Indicadores Ethos, devem fazer um comparativo com a matriz de critérios essenciais (ETHOS, 2006) e as metas do milênio ${ }^{10}$ e para verificar se suas ações estão alinhadas a essas duas referências. Esse comparativo também serve como direcionador para as possíveis ações que a empresa venha a implementar.

\section{PLANOS DE AÇÃO}

\section{D1. Priorizar metas}

Com base nos resultados obtidos nos Indicadores Ethos, e também nos demais materiais resultantes das etapas anteriores da metodologia, as empresas devem

\footnotetext{
${ }^{10}$ Os objetivos do milênio são um conjunto de oito macro-objetivos aprovados pelas Nações Unidas em setembro de 2000. O Brasil, em conjunto com 191 países-membros da ONU, assinou o pacto e assumiu o compromisso de atingir esses objetivos até 2015. Os objetivos do milênio são: 1. Acabar com a fome e a miséria; 2 . Educação básica de qualidade para todos; 3 . Igualdade entre sexos e valorização da mulher; 4.Reduzir a mortalidade infantil; 5 . Melhorar a saúde das gestantes; 6 . Combater a AIDS, a malária e outras doenças; 7. Qualidade de vida e respeito ao meio ambiente; 8. Todo mundo trabalhando pelo desenvolvimento. Disponível em http://www.nospodemos.org.br/objetivos.htm.
} 
priorizar as metas para implantação de sua nova gestão com base nos conceitos de responsabilidade social.

\section{D2. Correlacionar metas com fatores críticos do negócio}

As empresas devem identificar, dentro da realidade do seu negócio, quais são os impactos mais significativos e relacioná-los com as metas para elaborar o plano de ação.

\section{D3. Analisar o estudo da sustentabilidade da cadeia e do setor}

Essa etapa da metodologia sugere a realização de um estudo da cadeia e do setor em questão para que as informações obtidas sirvam de referência para potencializar as oportunidades de negócios e ações a serem desenvolvidas pelas empresas participantes.

\section{D4. Elaborar planos de ação}

Com base em todos os dados levantados até então com a aplicação da metodologia Tear, as empresas devem elaborar um plano de ação para identificar quais serão as ações a serem desenvolvidas para atender às demandas que julgarem necessárias e prioritárias, qual o prazo, os responsáveis, os recursos necessários, entre outras informações.

As empresas devem também compartilhar suas ações com os demais participantes do grupo, a fim de promover um intercâmbio de informações e também possíveis parcerias em ações específicas.

\section{D5. Implementar e monitorar planos de ação}

Após a elaboração do plano de ação, as empresas devem implementar as ações e monitorar os seus impactos na gestão do negócio. Nesse momento, a troca de experiências é fundamental para esclarecer dúvidas e reduzir as dificuldades de implantação.

O monitoramento deve ser constante, para retratar os resultados obtidos pelo Programa Tear. 


\section{E. COMUNICAÇÃO E RELATÓRIO}

\section{E1. Elaborar Balanço Social}

Essa etapa visa a elaboração de um documento público onde as empresas possam divulgar seu desempenho quanto à responsabilidade social.

Para auxiliar nesse processo, existem algumas ferramentas disponíveis com destaque para: o Guia Ethos de Elaboração do Balanço Social (ETHOS, 2007) e o Global Reporting Iniciative (GRI, 2006).

\section{E2. Validar Balanço Social}

Após a elaboração do relatório de Balanço Social, a empresa deve validar o conteúdo com as principais partes interessadas. Tais partes interessadas devem ser definidas com base no mapeamento de partes interessadas elaborado anteriormente. As partes interessadas devem ser consultadas e comunicadas das intenções das empresas, acertando dessa forma o meio de comunicação mais conveniente (reuniões presenciais, e-mail, telefone, etc.).

\section{F. CONSOLIDAÇÃO DA REDE}

\section{F1. Fortalecer as relações entre os participantes da rede}

As experiências, os aprendizados e os avanços devem ser constantemente compartilhados entre os membros do grupo formado, para que se estabeleçam relações duradouras, que perdurem após o término do Programa Tear.

\section{F2. Incorporar práticas do programa na gestão}

O objetivo da metodologia é que as empresas adotem as práticas desenvolvidas ao longo do programa em sua gestão, levando o conceito da sustentabilidade para a esfera de competitividade. 


\section{G. EXPANSÃO DA REDE}

\section{G1. Aplicar a metodologia Tear em novos grupos}

A metodologia do Programa Tear está sendo utilizada pela primeira vez e a idéia é que, após essa primeira experiência, os participantes desses grupos de trabalho estabeleçam novas redes para um novo início da metodologia, podendo atingir subfornecedores ou clientes da empresa participante, que ser tornará âncora do programa. Nesses novos grupos, as âncoras estariam livres para definir o número de empresas participantes e seu porte. 


\section{ESTUDO DE CASO}

Os estudos apresentados nesse capítulo foram selecionados de forma atender os objetivos iniciais da pesquisa. O estudo de caso do Programa Tear foi realizado para permitir a análise de sua implementação e fornecer subsídios para análise das dificuldades encontradas pelas empresas participantes.

Os estudos exploratórios realizados com três empresas participantes dessa iniciativa buscaram um melhor entendimento do impacto do Programa Tear na gestão de cada uma delas.

Os estudos de outras iniciativas setoriais semelhantes ao Tear em termos de capacitação de grupos de empresas também foram feitos para servirem de referência na análise do programa.

O levantamento das informações apresentadas referentes ao Programa Tear foi feito pela participação da pesquisadora nas reuniões mensais, e os demais estudos foram feitos por meio de entrevistas com os representantes das empresas e entidades abordadas.

Todas as informações obtidas nesse capítulo, juntamente com a revisão bibliográfica, foram utilizadas para a redação do capítulo 5 , que apresenta a análise do Programa Tear e a proposição de diretrizes para implementação de ações de responsabilidade social junto aos fornecedores de pequeno e médio porte de incorporadoras e construtoras.

\subsection{A experiência do Programa Tear}

O estudo de caso do Programa Tear foi realizado por meio da participação da pesquisadora nas reuniões no período de janeiro de 2007 a outubro de 2008. Em uma das reuniões, foi feita uma apresentação pela pesquisadora para todas as empresas participantes, com os objetivos da pesquisa e como seria o acompanhamento das reuniões. Nessa ocasião, houve o consentimento de todas as 
empresas participantes quanto à participação da pesquisadora no decorrer do programa, ficando as empresas dispostas a colaborar com a pesquisa.

As reuniões aconteceram mensalmente, buscando-se manter o mesmo dia da semana para o encontro, e duravam cerca de 8 horas. Como essa cadeia de valor foi uma exceção e possuía duas empresas âncoras, elas se revezavam para organizar os encontros. As empresas âncoras arcaram com todos os gastos referentes aos encontros (local, alimentação, estacionamento, recursos audiovisuais), e também foram responsáveis pela organização, envio de convites e posterior envio do material apresentado.

As empresas participantes tinham como compromisso a presença nas reuniões e também a participação nas atividades propostas, tanto durante o encontro como também o cumprimento das atividades a serem realizadas nas empresas.

O Instituto Ethos participou das reuniões com a presença das coordenadoras do programa. Duas consultoras em responsabilidade social foram contratadas para auxiliar no andamento do projeto, uma para conduzir as reuniões e outra para acompanhar as atividades desenvolvidas pelas pequenas e médias empresas participantes, tendo uma quantidade de sessenta e quatro horas definida para atender cada uma das empresas.

A dinâmica das reuniões foi composta pela apresentação da pauta, explicações sobre as ferramentas de gestão a serem trabalhadas no dia, dinâmicas para facilitar o aprendizado, atividades lúdicas, palestras de profissionais externos trazendo exemplos de ações de responsabilidade social, além do compartilhamento de experiências entre as empresas na apresentação de seus casos implantados ao longo do programa.

Para a aplicação da metodologia, foram programados 24 encontros de cada cadeia de valor e mais quatro seminários regionais, onde todas as cadeias de valor se reúnem para a troca de experiências.

Em alguns momentos durante a aplicação da metodologia, foram trazidos resultados parciais de cumprimentos das metas e atividades propostas para as empresas participantes. 
Para a apresentação do estudo de caso do Programa Tear, optou-se por seguir as macro-etapas da metodologia proposta para facilitar o entendimento das diversas fases percorridas ao logo dos encontros, descrevendo as principais informações coletadas.

\section{A. INÍCIO DA CONSTRUÇÃO DA REDE E SENSIBILIZAÇÃO}

O modelo do programa utilizado nessa primeira experiência foi definido pelo Instituto Ethos, indutor da iniciativa de capacitação das empresas em responsabilidade social.

Dentro de cada um dos setores pré-definidos, o Instituto Ethos tinha como premissa a definição de empresas âncoras. No caso da cadeia de construção civil - edifícios, a Y.Takaoka Empreendimentos S.A. foi convidada a participar do Programa Tear como âncora. Foram apresentadas as condições para participação, incluindo os recursos financeiros necessários para promover as reuniões de trabalho do grupo (incluindo a disponibilização de local, refeições, estacionamento, recursos audiovisuais, transporte e acomodação para representantes das empresas convidadas para os seminários regionais). Também foram apresentados os resultados e benefícios esperados do programa.

O Instituto Ethos solicitou à Y.Takaoka a definição da equipe responsável na empresa para coordenar o programa. A coordenadora de planejamento da Y.Takaoka foi nomeada para cumprir essa função, assumindo os compromissos de responsabilidade da âncora, como a organização dos encontros, a contribuição na organização dos seminários regionais e a participação nas reuniões periódicas entre as demais empresas âncoras.

Após a formalização da participação da Y.Takaoka, com as atribuições e responsabilidades definidas, o Instituto Ethos solicitou que fossem escolhidas 18 empresas da cadeia de clientes e fornecedores para compor o grupo a fazer parte do programa. A Y.Takaoka começou esse processo de escolha com uma lista de 100 possíveis empresas, porém se deparou com o fato de que, por ser uma incorporadora, muitas dessas empresas eram na verdade fornecedoras da construtora parceira de seus empreendimentos. Diante disso, decidiu convidar a 
construtora parceira Gafisa S.A. para participar como âncora do Programa Tear, formando então a única cadeia de valor com duas âncoras em relação às demais, e juntas definiram as pequenas e médias empresas fornecedoras a serem convidadas.

Após a escolha, foi feito então o convite às empresas para uma palestra ministrada pelo Eng. Marcelo Takaoka, presidente da Y.Takaoka, para apresentação do Programa Tear. As empresas foram informadas quanto às expectativas de resultados com a implantação de práticas de responsabilidade social na gestão, tempo de duração do programa, dinâmica, etc. e 18 empresas aceitaram o convite. Formou-se então a cadeia de valor da construção civil - incorporação, com as duas âncoras e as 18 pequenas e médias empresas, das mais variadas atividades, porém fornecedoras do setor.

\section{B. SENSIBILIZAÇÃO E ANÁLISE DA SUSTENTABILIDADE DO NEGÓCIO}

\section{B1. Estabelecimento dos compromissos e princípios de trabalho no grupo}

As empresas participantes, âncoras, o Instituto Ethos e as consultoras passaram a se reunir mensalmente para as reuniões de trabalho, denominadas GTs (grupos de trabalho).

No início da aplicação da metodologia, foi feita a apresentação da equipe do Instituto Ethos e das consultoras que acompanhariam o desenvolvimento do programa, além de todos os representantes das empresas participantes, com o intuito de integrá-los e explicitar as contribuições que cada um poderia trazer para o grupo. Houve também um momento de reflexão para estabelecimento dos compromissos e princípios norteadores do grupo, uma vez que as expectativas apresentadas por parte do Ethos para o desenvolvimento do programa foram a participação ativa de todos, o intercâmbio de opiniões, o respeito e abertura para novas opiniões e experiências e bom humor para a formação de um grupo de pessoas e não de cargos. Os compromissos e princípios adotados pelo grupo foram os apresentados na tabela 6. 
Tabela 6 - Princípios e compromissos assumidos pela cadeia de valor Y.Takaoka/Gafisa

\begin{tabular}{cc}
\hline PRINCÍPIOS & COMPROMISSOS \\
\hline Respeito à diversidade & Respeitar o cronograma \\
\hline Ouvir e questionar & Foco no objetivo \\
Ética & Presença \\
Objetividade & $\begin{array}{c}\text { Memória da reunião e } \\
\text { compromissos firmados }\end{array}$ \\
\hline Transparência & Multiplicação \\
\hline
\end{tabular}

Foi feita ainda uma reflexão para identificar a realidade atual das empresas participantes, onde elas pretendiam chegar pela participação no programa e o que poderia ser construído com por todo o grupo.

Com todo o alinhamento feito entre as empresas participantes, foi apresentada a metodologia do Programa Tear, conforme a figura 9.

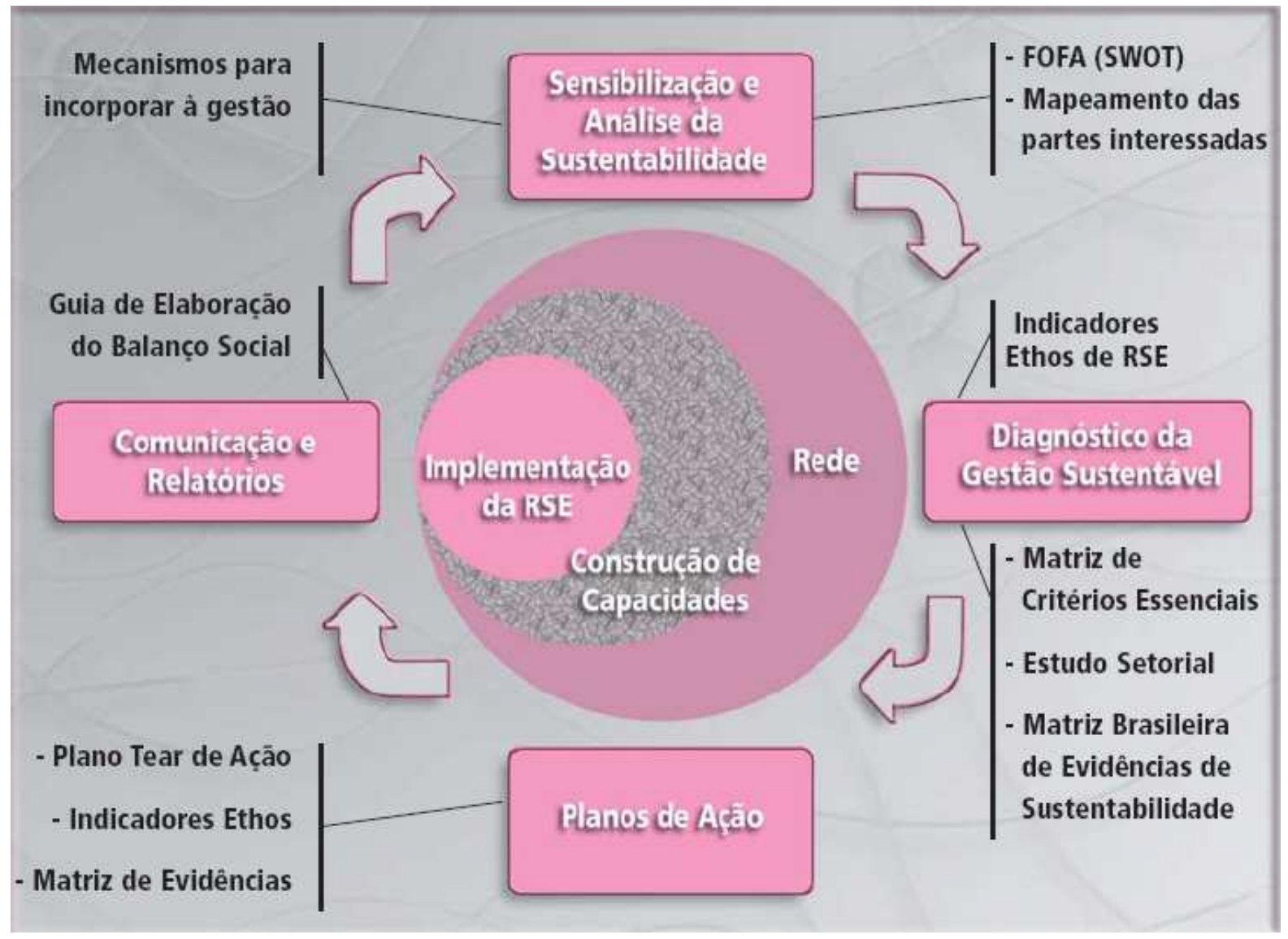

Figura 9 - Estrutura da Metodologia do Programa Tear (ETHOS, 2007)

Foi proposto um exercício para a construção de uma definição de responsabilidade social empresarial, que fosse elaborada em grupos de discussão com o auxílio de 
material oferecido pelas consultoras, com o objetivo principal de promover um maior envolvimento dos participantes com o tema. Após o término dessa atividade, foram então apresentadas as definições de responsabilidade social de alguns autores para discussão e nivelamento dos conceitos.

\section{B2. Sensibilização para a sustentabilidade}

A seqüência da metodologia foi a apresentação dos conceitos da sustentabilidade e a importância dos mesmos dentro da gestão das empresas. A diferença entre os conceitos de ação social, investimento social privado e responsabilidade social foi bastante enfatizada, especialmente para distinguir os públicos considerados em cada um deles. O conceito do triple bottom line (sustentabilidade empresarial baseada no tripé econômico, ambiental e social) também foi apresentado, finalizando a conceituação da importância desses conceitos para a gestão dos negócios.

Para complemento de informações e andamento da metodologia, os Indicadores Ethos de Responsabilidade Social Empresarial foram apresentados às empresas participantes do programa. O objetivo era que, ao responder os indicadores, as empresas pudessem identificar seu estágio de atuação em responsabilidade social. Foram apresentados os sete temas abordados nos indicadores (valores, transparência e governança, público interno, meio ambiente, fornecedores, consumidores e clientes, comunidade e governo e sociedade), e também a estrutura de cada um deles.

Apresentado então o modelo dos indicadores, foi proposta a seguinte seqüência para a inserção do tema da responsabilidade social na gestão das empresas, como resumo da metodologia do Programa Tear, ilustrada na tabela 7.

Cada empresa teve como compromisso responder os indicadores internamente com seus colaboradores, podendo optar pelos Indicadores Ethos ou Indicadores EthosSebrae, recomendados para micro e pequenas empresas. 
Tabela 7 - Etapas da inserção da responsabilidade social na gestão das empresas

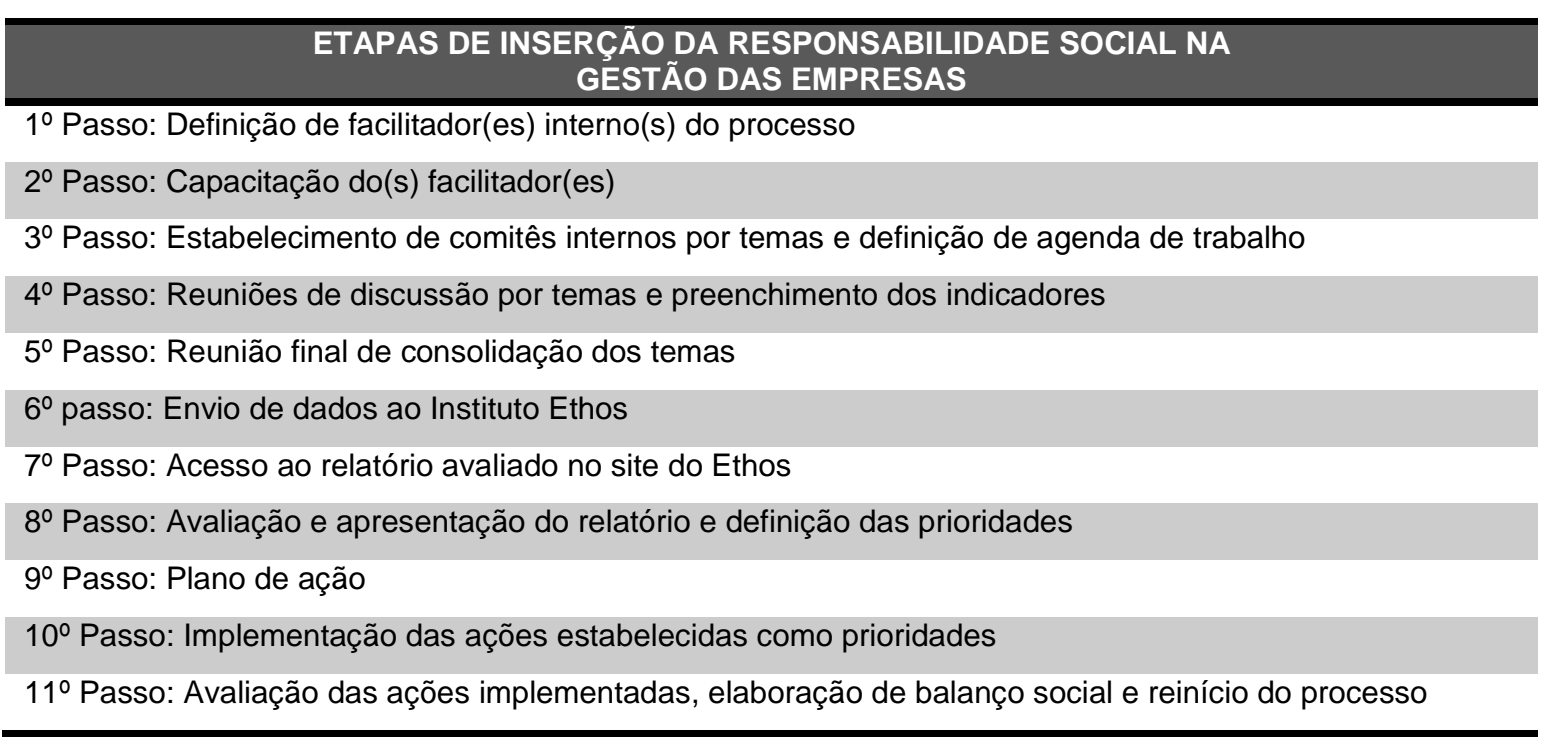

Outra abordagem da metodologia do Programa Tear foi a capacitação das empresas quanto a sua estratégia de atuação no mercado. Para isso, foram apresentados os conceitos de missão, visão, princípios e valores, que posteriormente foram exemplificados pelas empresas âncoras Y.Takaoka e Gafisa. Foi solicitada a cada uma das empresas participantes uma reflexão para a elaboração de sua missão, visão, princípios e valores, especialmente considerando a questão da responsabilidade social, já que é uma das etapas da metodologia.

\section{B3. Análise do negócio sob a ótica da sustentabilidade}

A análise do negócio sob a ótica da sustentabilidade baseou-se na utilização da ferramenta análise SWOT ou FOFA, onde cada empresa deveria fazer um levantamento de suas forças e fraquezas, oportunidades e ameaças. Esse levantamento foi mais uma ferramenta para o levantamento de informações sobre o negócio para orientar as ações a serem planejadas e desenvolvidas no futuro.

\section{B4. Mapeamento das partes interessadas}

O mapeamento de partes interessadas foi proposto para que as empresas identificassem e conhecessem as partes impactadas pelo seu negócio, e avaliassem os impactos de suas atividades em cada uma delas. Para isso, foram apresentados os conceitos do que são as partes interessadas, quais as partes interessadas podem fazer parte do mapeamento de cada empresa e qual a importância do engajamento 
das partes interessadas para a gestão socialmente responsável. Também foi esclarecido o conceito de que as partes interessadas podem ser positivas, negativas ou neutras para cada negócio. Foram ainda exibidos diversos modelos de como o mapeamento das partes interessadas poderia ser representado graficamente: a empresa no centro e as partes interessadas ao redor, a classificação das partes interessadas internas e externas, a teia de inter-relações entre a empresa e as partes interessadas e das partes interessadas entre si, o modelo "guarda-chuva" de partes interessadas e a interligação entre todos os envolvidos, conforme os temas dos Indicadores Ethos. Foi então recomendado que cada empresa seguisse as recomendações do referencial normativo $A A 1000$ para elaboração de seu mapa de partes interessadas, ou stakeholder mapping, e foram apresentados diversos exemplos de mapeamento de partes interessadas de outras empresas, inclusive das âncoras.

Foi sugerido um modelo de tabela (tabela 8) para o levantamento das informações referentes às partes interessadas.

Tabela 8 - Modelo para levantamento de informações das partes interessadas

\begin{tabular}{|c|c|c|c|c|c|}
\hline $\begin{array}{c}\text { Parte } \\
\text { interessada }\end{array}$ & Risco & Oportunidade & $\begin{array}{c}\text { Impacto da } \\
\text { empresa sobre }\end{array}$ & $\begin{array}{l}\text { Compromisso } \\
\text { da empresa com }\end{array}$ & $\begin{array}{c}\text { Formas de } \\
\text { diálogos } \\
\text { existentes }\end{array}$ \\
\hline \multicolumn{6}{|l|}{ Fornecedor } \\
\hline \multicolumn{6}{|l|}{ Cliente } \\
\hline \multicolumn{6}{|l|}{$\cdots$} \\
\hline & & & & & \\
\hline & & & & & \\
\hline & & & & & \\
\hline \multicolumn{6}{|l|}{$\ldots$} \\
\hline$\ldots$ & & & & & \\
\hline
\end{tabular}

\section{B5. Identificar o estágio de desenvolvimento em gestão sustentável}

Foi apresentada às empresas uma tabela de interfaces entre as possíveis atitudes e o respectivo posicionamento em relação à responsabilidade social, para que pudessem se posicionar quanto ao seu estágio atual e também suas perspectivas futuras, conforme ilustra a tabela 9. 
Tabela 9 - Atitudes e posicionamento de empresas em relação à RSE

\begin{tabular}{|c|l|l}
\hline Estágio & $\begin{array}{l}\text { O que as empresas } \\
\text { fazem? }\end{array}$ & Por que? \\
\hline Defensivo & $\begin{array}{l}\text { Negam práticas, impactos e } \\
\text { responsabilidades. }\end{array}$ & $\begin{array}{l}\text { Para defender-se de ataques contra a } \\
\text { reputação, que podem afetar, a curto } \\
\text { prazo, vendas, recrutamento, } \\
\text { produtividade e marca. }\end{array}$ \\
\hline Cumprindo & $\begin{array}{l}\text { Adotam uma política de } \\
\text { cumprimento como custo } \\
\text { integrado dos negócios. }\end{array}$ & $\begin{array}{l}\text { Para amenizar a erosão de valores } \\
\text { econômicos em médio prazo, devido a } \\
\text { riscos de processos jurídicos e para a } \\
\text { reputação. }\end{array}$ \\
\hline Administrando & $\begin{array}{l}\text { Integram assuntos sociais } \\
\text { na gestão do negócio. }\end{array}$ & $\begin{array}{l}\text { Para amenizar a erosão de valores } \\
\text { econômicos em médio prazo e atingir } \\
\text { resultados positivos a longo prazo, } \\
\text { integrando práticas responsáveis no dia-a- } \\
\text { dia das operações. }\end{array}$ \\
\hline Estratégico & $\begin{array}{l}\text { Integram assuntos sociais } \\
\text { na estratégia do negócio. }\end{array}$ & $\begin{array}{l}\text { Para assegurar valores econômicos a } \\
\text { longo prazo e ganhar pioneirismo no } \\
\text { alinhamento da estratégia e de processos } \\
\text { inovadores com assuntos sociais. }\end{array}$ \\
\hline Agente civil & $\begin{array}{l}\text { Promovem participação } \\
\text { da indústria na responsabi- } \\
\text { lidade social empresarial }\end{array}$ & $\begin{array}{l}\text { Para assegurar valores econômicos a } \\
\text { longo prazo e gerar mais resultados } \\
\text { positivos por meio de ações coletivas. }\end{array}$ \\
\hline
\end{tabular}

\section{DIAGNÓSTICO DA GESTÃO SUSTENTÁVEL}

\section{C1. Aplicação dos Indicadores Ethos}

Foi realizada uma oficina para orientar as empresas com relação ao preenchimento dos Indicadores Ethos. Foi apresentado um passo a passo para melhor representar as etapas necessárias para responder os indicadores.

Esse passo a passo apresentado para as empresas teve o objetivo de delinear mais claramente tanto a aplicação dos indicadores como também o caminho a ser percorrido ao longo da metodologia do Programa Tear. Porém, diversas ferramentas ainda foram apresentadas para auxiliar no processo de elaboração do plano de ação, implementação das ações e elaboração do balanço social.

\section{C2. Realização da análise qualitativa das práticas de RSE na empresa}

A Matriz de Critérios Essenciais de responsabilidade social foi apresentada às empresas para servir como base para alinhamento das ações a serem realizadas em função dos resultados dos Indicadores Ethos. As metas do milênio também foram 
apresentadas e serviram como fonte para elaboração do plano de ações das empresas participantes.

O conceito de ética foi apresentado às empresas também para subsídio da elaboração do plano de ação. Empresas mais avançadas no processo foram convidadas a apresentar seus processos de elaboração dos seus códigos de ética para subsidiar os demais participantes da importância dessa ferramenta.

Outra ferramenta apresentada às empresas para auxílio na elaboração do plano de ação foi o Banco de Práticas do Instituto Ethos ${ }^{11}$, onde ações já realizadas por outras empresas servem de exemplo para o desenvolvimento de novas ações.

\section{PLANOS DE AÇÃO}

\section{D1. Priorizar metas}

Por meio da análise dos resultados dos Indicadores Ethos e também considerando a realidade de cada empresa, as metas a serem definidas deveriam atender às necessidades mais evidentes, buscando suprir as demandas mais urgentes.

\section{D2. Correlacionar metas com fatores críticos do negócio}

A correlação entre as metas da empresa e os fatores críticos do negócio foi tratada de maneira implícita nas demais etapas da metodologia, como na aplicação na análise SWOT.

\section{D3. Analisar o estudo da sustentabilidade da cadeia e do setor}

O Instituto Ethos contratou uma empresa para realizar um estudo da cadeia da construção civil, a fim de fornecer subsídios ao Programa Tear, buscando orientar e focar as ações das empresas também em busca de melhorias para o setor. Para essa atividade, diversos profissionais do setor, entre eles acadêmicos e empresários, foram convidados para uma reunião de validação do estudo.

\footnotetext{
${ }^{11}$ Disponível em http://www.ethos.org.br/docs/conceitos_praticas/banco_praticas/default.htm
} 


\section{D4. Elaborar planos de ação}

Com todas as atividades desenvolvidas até então, as empresas participantes do programa tiveram a tarefa de desenvolver seu plano de ação. Os resultados dos Indicadores Ethos, associados à missão, visão e valores das empresas, o mapeamento das partes interessadas mais a matriz de critérios essenciais, o estudo setorial e a matriz brasileira de evidências de sustentabilidade serviram de informações de entrada para a elaboração do plano de ação.

Inicialmente as empresas deveriam realizar um exercício interno de reflexão para definir suas prioridades, recursos disponíveis (físicos, humanos e financeiros), e suas expectativas. Foi apresentado um roteiro para que as empresas tivessem idéia do que deveria constar no plano de ação, ilustrado na figura 10.

\begin{tabular}{|lll|}
\hline \multicolumn{2}{|c|}{$\begin{array}{c}\text { Item do } \\
\text { Plano de Ação }\end{array}$} & \multicolumn{1}{c|}{ Descrição } \\
1. & Situação atual & $\begin{array}{l}\text { Descrição da situação atual, incluindo política, procedimentos e } \\
\text { práticas existentes em relação a cada um dos Indicador Ethos de } \\
\text { RSE. }\end{array}$ \\
2. & Causas & Lista das razões que levaram à situação atual. \\
3. & Ações & Atividades práticas e viáveis para aprimorar o sistema de gestão. \\
4. & Metas & $\begin{array}{l}\text { Metas mensuráveis, realistas e acordadas com as partes } \\
\text { interessadas. Prever metas para os diferentes prazos do plano de } \\
\text { ação (imediato, médio e longo prazo). }\end{array}$ \\
5. & Responsável & $\begin{array}{l}\text { Definição de quem terá competência e responsabilidade pela } \\
\text { implantação das ações. }\end{array}$ \\
6. & Prazo & Definição do prazo para implantação das ações pelo responsável. \\
\hline
\end{tabular}

Figura 10 - Roteiro para plano de ação

Alguns exemplos de plano de ação de outras empresas foram trazidos para ilustrar o resultado final do plano de ação. Algumas empresas utilizaram a ferramenta "5W2H"12 para montar o plano de ação.

${ }^{12}$ A ferramenta " $5 \mathrm{~W} 2 \mathrm{H}$ " consiste no levantamento de informações com base nas palavras em inglês what (o que), why (por que), where (onde), when (quando), who (quem), how (como) e how much (quanto). 
Alguns planos de ação foram mais bem elaborados, em função do porte da empresa e também dos recursos disponíveis para realização das ações. Algumas empresas acabaram revisando seu plano por estarem com muitas atividades previstas.

A maioria das empresas participantes focou o público interno como principal tema a ser tratado. A apresentação dos planos de ação pelas empresas foi importante para a troca de experiências e o intercâmbio de idéias, e também para acompanhamento da implementação das ações ao longo do programa.

\section{D5. Implementação e monitoramento dos planos de ação}

Ao longo do programa, as empresas deveriam implementar seus planos de ação aos poucos e trazer os resultados parciais nas reuniões mensais do grupo.

\section{E. COMUNICAÇÃO E RELATÓRIO}

\section{E1. Elaboração do Balanço Social}

O balanço social é um documento no qual as empresas podem divulgar seu desempenho em um determinado período, inclusive suas ações de responsabilidade social, a ser divulgado para todas suas partes interessadas.

Durante o Programa Tear, foram apresentados alguns modelos de elaboração de balanço social, como o Guia Ethos de Elaboração do Balanço Social, o Balanço Social Ibase e o Global Reporting Iniciative. Esses modelos serviram como base para que as empresas pudessem elaborar os seus próprios balanços, ficando a cargo de cada uma definir a relevância das informações a serem publicadas. $O$ modelo $G R I$ não foi utilizado no grupo das empresas participantes devido a sua complexidade e por exigir um maior investimento de tempo, recursos financeiros e maior envolvimento e maturidade da empresa com o tema da responsabilidade social.

No $3^{\circ}$ seminário regional do Programa Tear, realizado no dia 30 de abril de 2008, as empresas participantes de todas as cadeias de valor, inclusive a de construção civil, puderam divulgar seus balanços sociais em meio eletrônico, distribuído a todos os participantes do evento. Na ocasião, nove empresas da cadeia da construção civil 
publicaram seu balanço social. Os formatos foram diversos, desde o simples preenchimento do modelo lbase à apresentação de slides, além de relatórios mais aprimorados. Houve também a diferença entre as informações abordadas em cada um deles, com mais ou menos ênfase em determinados assuntos.

\section{E2. Validação do Balanço Social}

Em função do prazo de entrega do balanço social para o seminário regional, não foi realizada a validação do mesmo com as partes interessadas das empresas. $O$ balanço social foi o relato das ações realizadas pelas empresas.

\section{F. CONSOLIDAÇÃO DA REDE}

\section{F1. Fortalecimento das relações entre os participantes da rede}

Nas reuniões acompanhadas ao longo do programa, algumas evidências de fortalecimento das relações entre os participantes da rede puderam ser constatadas por algumas trocas de contatos para realização de trabalhos em parcerias e indicações entre as empresas participantes.

\section{F2. Incorporação das práticas do programa na gestão}

A incorporação das práticas do programa na gestão das empresas ainda não pode ser efetivamente constatada, uma vez que o programa ainda não foi finalizado, e mesmo com seu encerramento, essa percepção será de longo prazo.

\section{G. EXPANSÃO DA REDE}

\section{G1. Aplicação da metodologia Tear em novos grupos}

Ainda não foram constatadas evidências da continuidade do Programa Tear na cadeia da construção civil.

Cabe salientar que as informações apresentadas nesse capítulo foram as constatações feitas ao longo das reuniões do Programa Tear. A análise dessas constatações será feita no capítulo 5 . 


\subsection{Instituto Ethos}

O estudo junto ao Instituto Ethos teve por objetivo complementar as informações referentes ao Programa Tear. As informações apresentadas foram obtidas por meio de entrevista concedida por telefone por Patrícia Sogayar, coordenadora da iniciativa do Programa Tear. A entrevista foi concedida em duas ocasiões, nos meses de maio e setembro de 2008 conforme roteiro apresentado no apêndice 2 dessa dissertação.

Segundo Patrícia Sogayar, a idéia da criação do Programa Tear surgiu de uma conversa entre a presidência do Banco Interamericano de Desenvolvimento e a diretoria do Instituto Ethos. Após esse contato inicial, o Instituto Ethos começou a escrever o programa e teve como inspiração a iniciativa da ArcelorMittal (antiga Belgo Mineira), que já havia abordado o tema da responsabilidade social com seus fornecedores. Foram consultadas ainda outras seis organizações que já trabalhavam o conceito de cadeia de valor, entre elas a CPFL, Banco ABN Real, Natura, FIEB e O Boticário.

Após a idéia inicial, o programa começou a ser efetivamente desenvolvido e contou com a validação de mais de 80 organizações, dentre elas empresas da iniciativa privada, organizações não-governamentais e consultores da área de responsabilidade social.

Entre a conversa inicial entre o Instituto Ethos e BID e a aprovação final da metodologia, foram necessários 2 anos. Após a aprovação final da metodologia, ainda houve mais um ano para planejamento operacional e contratação e treinamento da equipe de trabalho do Instituto Ethos.

Os custos referentes ao programa foram divididos pelo BID e pelas empresas âncoras. O BID arcou com $50 \%$ dos custos da iniciativa e os outros $50 \%$ ficaram por conta de cada uma das empresas âncoras das diversas cadeias de valor.

A iniciativa para atuação com pequenas e médias empresas foi um pré-requisito do BID, uma vez que o fundo que financiou o programa só trabalha com empresas desse porte. 
Segundo Patrícia, trabalhar com empresas de maior porte poderia fazer com que o conceito de responsabilidade social fosse sim mais disseminado nas cadeias de valor, porém a maioria das empresas no Brasil está classificada entre pequena e média, e investindo nessa categoria seria desmistificada a afirmação de que os investimentos em responsabilidade social só podem ser feitos em empresas de grande porte.

O processo de escolha das cadeias de valor a serem trabalhadas no Programa Tear passou por uma primeira triagem, para identificação dos setores "de impacto" na sociedade, com alto poder de transformação. Após a identificação dos setores, em cada um deles foram pesquisadas empresas que já desenvolvessem ações de responsabilidade social, que poderiam ser "líderes" em suas cadeias de valor, e que tivessem algum relacionamento com o Instituto Ethos. Essas empresas foram inicialmente abordadas de maneira informal pela diretoria do Instituto Ethos para identificação das "âncoras" em potencial. Num segundo momento, foi formalizada uma declaração de interesses por parte dessas empresas na participação do Programa Tear e, após a definição de todas as empresas âncoras, foi realizada uma reunião entre o BID e todas as empresas escolhidas e foi emitido um termo de compromisso entre todos os participantes.

Fizeram parte desse termo de compromisso das empresas âncoras itens como o comprometimento em participar e dar continuidade ao programa, arcar com os custos dos encontros mensais, disponibilizar um colaborador interno para acompanhar o programa e replicar a metodologia. Ao longo do programa, foi constatado que algumas âncoras cumpriram além das exigências e outras não conseguiram atender ao termo de compromisso.

Para a aplicação da metodologia do programa, as âncoras tiveram que escolher pequenas e médias empresas de sua cadeia de valor a serem posteriormente convidadas a participar do Programa Tear. A definição das empresas a serem convidadas foi resultado de uma reunião entre a direção das empresas âncoras e Instituto Ethos para definir em que parte da cadeia de valor o programa "faria mais sentido". As empresas convidadas foram escolhidas conforme a necessidade de cada setor (podendo ser escolhidos clientes ou fornecedores), usando-se como critérios a percepção da âncora quanto ao comprometimento e abertura das 
pequenas e médias empresas para o investimento em responsabilidade social. Após a definição, foi feito um evento de pré-lançamento em cada cadeia de valor para apresentação da metodologia do Programa Tear e do termo de compromisso a ser assumido pelas empresas que optassem por participar do grupo de trabalho.

Durante o programa, o Ethos teve o papel de coordená-lo, alinhar os conceitos junto às "âncoras", articular as ações a serem desenvolvidas, controlar os produtos e ferramentas a serem utilizados e elaborar e colocar em prática a política e plano de comunicação dos grupos de trabalho.

Os resultados do programa foram acompanhados por meio das linhas de base, que são indicadores do cumprimento de cada uma das atividades propostas ao longo do Programa Tear. As linhas de base foram medidas pela consultora do Instituto Ethos por meio de entrevistas com as empresas participantes.

Após o encerramento da primeira edição do Programa Tear em todas as cadeias de valor, ele se tornará uma ferramenta do Instituto Ethos para disseminação do conceito de responsabilidade social em cadeia. Essa primeira edição foi um grupo piloto com potencial de expansão tanto pelos representantes setoriais que participaram como também por meio das próprias pequenas e médias empresas. Novas empresas já mostraram interesse em se tornarem âncoras de próximas edições, e dessa forma o programa estará disponível no Uniethos ${ }^{13}$ para grupos de empresas, que arcarão com os custos referentes a implantação da metodologia. $O$ Ethos ainda possui outras iniciativas para atuação junto a empresas de pequeno e médio porte, como os Indicadores Ethos-Sebrae e o Guia Passo-a-Passo, mas a criação e disseminação dessas ferramentas é uma tendência, já que aproximadamente $70 \%$ das empresas associadas ao Ethos são de pequeno e médio porte. Mas de qualquer forma, todas as ferramentas desenvolvidas sempre buscam atingir todos os portes de empresas.

\footnotetext{
${ }^{13}$ O UniEthos - Educação para a Responsabilidade Social e o Desenvolvimento Sustentável é uma instituição sem fins lucrativos voltada à pesquisa, produção de conhecimento, instrumentalização e capacitação para o meio empresarial e acadêmico nos temas da Responsabilidade Social Empresarial (RSE) e Desenvolvimento Sustentável (DS). Disponível em <www.uniethos.org.br>.
} 


\subsection{Empresa âncora Y. Takaoka}

O estudo da empresa "âncora" do Programa Tear Y.Takaoka Empreendimentos S.A. teve por objetivo o entendimento da participação da empresa no programa e das ações de responsabilidade social que desenvolveu. A Eng ${ }^{a}$ Gláucia Sato, coordenadora de planejamento da Y.Takaoka na ocasião, concedeu uma entrevista nas instalações da empresa em 7 de maio de 2008, conforme o roteiro apresentado no apêndice 3 dessa dissertação.

A Y.Takaoka Empreendimentos S.A. é uma incorporadora fundada em 1995 que tem como principal atividade o desenvolvimento de projetos urbanização para construção de loteamentos residenciais. Possui certificação na norma NBR ISO 14001 e o selo Forest Stewardship Council - FSC ${ }^{14}$, Certificação de Neutralização de Carbono emitido pela BRTÜV. O escopo do sistema de gestão ambiental (SGA) da empresa é o "Projeto Gênesis - Desenvolvimento Urbano Sustentável: Prospecção, modelagem, projeto, comercialização, implantação e entrega".

As iniciativas de responsabilidade social já fazem parte da atuação empresa desde sua fundação, em função do idealismo de seus líderes, inicialmente Yojiro Takaoka e atualmente Marcelo Vespoli Takaoka. O Projeto Genesis, linha de empreendimentos residenciais de destaque da empresa, já foi concebido com base em premissas de preservação ambiental e ações sociais, sendo que seu SGA é certificado na norma NBR ISO 14001.

A empresa preenche os Indicadores Ethos de Responsabilidade Social desde 2002 e o desempenho tem sido aperfeiçoado ano a ano, reflexo do envolvimento da alta direção com o tema. Em relação à questão ambiental, são promovidas palestras de educação ambiental em escolas municipais no entorno dos empreendimentos e a conscientização ambiental de todas as partes interessadas envolvidas no negócio, como também são voltadas ao público interno, como as escolas de alfabetização nos canteiros de obras. Os investimentos financeiros dessas ações são controlados separadamente.

\footnotetext{
${ }^{14}$ A certificação é um processo voluntário em que é realizada uma avaliação de um empreendimento florestal, por uma organização independente, a certificadora, e verificado os cumprimentos de questões ambientais, econômicas e sociais que fazem parte dos Princípios e Critérios do FSC. Disponível em <www.fsc.org.br>, acessado em 18 de maio de 2008.
} 
Segundo a Eng ${ }^{a}$ Gláucia Sato, a empresa não explora comercialmente os resultados advindos dos investimentos em responsabilidade social, busca na verdade a melhoria do relacionamento com suas partes interessadas, trazendo benefícios indiretos para a empresa.

Atualmente, os aspectos que a empresa julga mais importantes a serem tratados na responsabilidade social empresarial são o meio ambiente, fornecedores e público interno. Na questão ambiental, entre outras atividades, a empresa preserva áreas maiores do que as exigidas por lei em seus loteamentos e utiliza madeira certificada. Em relação aos seus fornecedores, busca contratar fornecedores locais, porém não tem política formal de escolha de fornecedores, apesar de dar preferência para fornecedores que possuem ações de responsabilidade social. Também procura empregar funcionários da comunidade do entorno.

As principais ações de responsabilidade social da empresa são divulgadas no relatório de sustentabilidade baseado no modelo do GRI (Global Report Iniciative).

Em relação ao Programa Tear, a Y.Takaoka também auxiliou no desenvolvimento da metodologia juntamente ao BID, ao Ethos e a outras empresas. Inicialmente, como estratégia da empresa, foram priorizadas as ações de responsabilidade social no tema público interno e fornecedores. Segundo a Enga Gláucia Sato, os reflexos já podem ser notados da empresa, já que "os funcionários mais satisfeitos influenciam nos resultados, especialmente no relacionamento com os clientes". A participação no Programa Tear também "aumentou a disseminação do conhecimento da empresa sobre o tema, auxiliando no processo de colocar em prática todas as idéias e expectativas em torno dele".

A empresa acredita que a utilização de exemplos de sucesso é uma ferramenta importante no engajamento de organizações a investirem em responsabilidade social.

\section{Programa Tear}

A Y.Takaoka foi convidada a participar do Programa Tear pelo engajamento que já demonstrava pelo tema e também pela aproximação já existente com o Instituto 
Ethos, uma vez que a Y.Takaoka já era associada A Y.Takaoka participou do programa desde o início de sua concepção.

Como âncora do Programa Tear, teve a tarefa de selecionar os fornecedores e convidá-los a participar das atividades ao longo de 24 encontros. Como a empresa tem foco na incorporação, alguns de seus fornecedores eram contratados diretamente pela Gafisa, empresa contratada para a construção do Loteamento Residencial Gênesis II. Diante disso, o Eng ${ }^{\circ}$ Marcelo V. Takaoka resolveu convidar a Gafisa para, junto a Y.Takaoka, ser âncora no Programa Tear.

Inicialmente, selecionaram 100 fornecedores e desses os critérios foram se restringindo até chegar nas 18 solicitadas pelo Ethos, priorizando empresas que já eram parceiras.

Quanto à dedicação necessária, a Y.Takaoka teve como compromisso definir uma pessoa que acompanhasse o programa e desse apoio em termos de logística e investimento financeiro para a realização dos encontros mensais e dos seminários regionais. A cada trimestre, as empresas âncoras se reúnem com a equipe do Instituto Ethos para discutir assuntos diversos, desde o orçamento do programa até as ações de sucesso.

Como principal benefício da participação no Programa Tear, a empresa identifica o aumento da confiança nas relações com o fornecedor, já que ele já conhece a forma de trabalho da Y.Takaoka e suas preocupações sócio-ambientais, estando capacitado para atender essas demandas.

\section{Relacionamento com fornecedores}

No relacionamento da Y.Takaoka com seus fornecedores, o contrato de prestação de serviços possui cláusulas com a proibição de trabalho infantil e análogo ao escravo, exigências em relação ao meio ambiente, mas não exige nenhuma certificação dos fornecedores. Apenas checam a "lista suja" do Ministério do Trabalho e Emprego, o fornecimento correto de nota fiscal e a ausência de sonegação de impostos. Além disso, entregam o código de conduta da empresa em suas relações comerciais para apresentar sua postura de trabalho. Na contratação de construtoras, a empresa anexa ao contrato um manual de procedimentos de 
execução com temas sobre a qualidade dos serviços e meio ambiente. A arquitetura dos Loteamentos Residenciais Gênesis I e II foram alinhadas aos conceitos de sustentabilidade.

Fazem essas exigências por filosofia da empresa. Os projetos são personalizados, pois a meta é "atender o sonho dos clientes".

\section{Relacionamento com clientes}

Os clientes da Y.Takaoka não fazem exigências específicas relacionadas à responsabilidade social, porém a empresa procura influenciá-los de alguma forma, propondo diretrizes sustentáveis do loteamento para a posterior construção das casas, sugerindo arquitetos com "apelo sustentável" para os clientes e promovendo palestras de conscientização.

A empresa acredita que, para que o setor mude sua realidade em relação a responsabilidade social, é necessário que a empresa como um todo, desde a alta direção até o nível operacional, tenha maior dedicação ao tema, para que "o assunto não fique em segundo plano e as ações aconteçam". A empresa identifica o público interno como o principal foco de investimento em responsabilidade social, atuando nas questões de segurança e de melhores condições de valorização profissional e cuidado com o ser humano.

\subsection{Fornecedores da Y.Takaoka e Gafisa}

As empresas âncoras Y. Takaoka e Gafisa convidaram 18 empresas de pequeno e médio porte para participarem do Programa Tear. Em virtude da decisão por realizar estudo com apenas três empresas participantes, algumas exercem atividades que atendem diversos setores, não somente o setor de construção civil e em função disso, foram definidos alguns critérios para escolha das empresas a serem estudadas: 
- a empresa deve ter sua atividade principal diretamente relacionada ao setor da construção civil (projetos, consultoria, prestação de serviço em obras, etc.), pois dessa forma retrata-se melhor o panorama do setor;

- a empresa deve ter comprometimento com o Programa Tear (presença nas reuniões e cumprimento de atividades propostas).

As empresas foram assim selecionadas e os estudos foram realizados com três empresas de pequeno e médio porte sediadas na região metropolitana de São Paulo, entre março e abril de 2008. As informações das empresas foram obtidas por meio de entrevistas com seus representantes, utilizando-se o questionário apresentado no apêndice 4 como roteiro.

\subsubsection{Empresa $A$}

O estudo da empresa A foi realizado por meio de entrevista com a arquiteta Luciana Tomas, diretora do escritório Luciana Tomas Arquitetura, realizada em 14 de março de 2008.

\section{Caracterização da empresa estudada}

A empresa A é um escritório de arquitetura, localizado no município de São Paulo, cuja principal atividade é o projeto e design de interiores. A empresa foi fundada em 1995 pela sua diretora e atualmente possui 25 colaboradores.

Fornece aos seus clientes projetos de decoração para interiores, apartamentos modelo e stands de vendas e também executa projetos de arquitetura para residências e estabelecimentos comerciais. Ainda agrega aos seus projetos a alternativa de acompanhamento da execução dos mesmos, nesse caso fazendo também as contratações necessárias de mão-de-obra, materiais e serviços.

Como expectativa para o futuro, a empresa pretende atuar de forma mais representativa em projetos de hotéis e residências e também em projetos mais focados no cuidado e bem estar das pessoas. 
$\mathrm{Na}$ ocasião da entrevista, a empresa utilizava a metodologia $5 \mathrm{~S}^{15}$ para gestão das atividades do escritório, e possuía ainda um sistema de gestão informatizado e um manual de normas e procedimentos internos. O gerente administrativo-financeiro da empresa, Leôncio Pedrosa, participava de um curso de especialização sobre sistema de gestão integrada, que pretendia implantar no escritório no futuro.

\section{Responsabilidade social}

A empresa já conhecia o conceito de responsabilidade social, julgando o público interno e o meio ambiente como os aspectos mais importantes a serem tratados.

$\mathrm{Na}$ ocasião da entrevista, a empresa não tinha conhecimento de ações de seus concorrentes em relação a responsabilidade social.

\section{Programa Tear}

A empresa decidiu participar do Programa Tear em função da palestra promovida pelo $\mathrm{Eng}^{\circ}$ Marcelo Takaoka para apresentação do programa, e também porque já possuía relações comerciais com a Y.Takaoka.

Analisa a dinâmica do programa como boa, porém acha que as reuniões poderiam ser realizadas a cada quinze dias e apenas no período da manhã, reduzindo a carga horária por reunião e não sendo necessário inclusive o almoço oferecido pelas âncoras. Acredita que o período da manhã é mais produtivo.

O principal benefício obtido pela empresa em sua participação no Programa Tear até o momento foi a maior conscientização da importância de sua responsabilidade social perante as partes interessadas.

A empresa declara ter participado de todas as reuniões do Programa Tear mensalmente e, todas as segundas-feiras pela manhã, eram apresentadas as discussões acerca do programa na pauta de suas reuniões semanais. A cada

${ }^{15}$ O 5 S surgiu no Japão no início dos anos 1950. Na indústria, seus principais papéis são: liberar áreas, evitar desperdícios, melhorar relacionamentos, facilitar as atividades e localização de recursos disponíveis. Trata de uma sigla formada pelas iniciais de cinco palavras japonesas. Disponível em $<w w w .5 s . c o m . b r>$. Acesso em: 18/05/2008. 
reunião do Tear, a empresa procurava levar um colaborador da empresa para conhecer o programa.

Todas as ações propostas pelo Programa Tear foram implantadas pela empresa, porém, mesmo antes do programa, o gerente administrativo financeiro Leôncio Pedrosa, com sua experiência em gestão de pessoas, já implantava algumas ações pontuais. A empresa acredita que o Programa Tear ainda precisa exigir um maior comprometimento dos participantes para que os resultados sejam mais evidentes.

Os reflexos mais evidentes do Programa Tear na gestão da empresa são: um grupo de trabalho mais coeso e comprometido; a busca de informações sobre assuntos relacionados à responsabilidade social e abertura para novas idéias e soluções para os projetos; a criação da missão, visão e valores da empresa; a implantação de coleta seletiva e programa de racionalização do uso de energia; elaboração de regimento interno para colaboradores; desenvolvimento de folder sustentável para apresentação de soluções alternativas aos clientes; caderno de normas e procedimentos de arquitetura e relatório para construções sustentáveis; melhoria do programa 5S; adoção de toda papelaria da empresa em papel reciclado; distribuição de brindes sustentáveis; realização de projetos com soluções sustentáveis e incentivo dos colaboradores a participarem de programas de capacitação.

A empresa julga estar bastante envolvida com o tema da responsabilidade social, e tem se empenhado para incluir a sustentabilidade em seus projetos de maneira mais representativa, buscando apresentar aos clientes as soluções possíveis em cada situação.

Como os aspectos de público interno e meio ambiente já eram considerados os mais importantes para a empresa mesmo antes do Programa Tear e já havia um projeto para implantação de ações com o público interno, essa intenção foi alinhada ao Programa Tear.

Quanto aos benefícios de investir em responsabilidade social, a empresa identifica que houve um "ganho significativo de sua imagem em relação ao público interno", já que as pessoas que trabalham na empresa têm consciência que a mesma está preocupada com a questão ambiental. Em relação ao relacionamento com os 
clientes, ainda não houve um benefício direto, porém a empresa tem investido em disseminar a cultura da responsabilidade social por meio de brindes, contatos pessoais, e pela divulgação do Programa Tear em todas as ocasiões possíveis. No relacionamento com fornecedores, a empresa busca também disseminar os conceitos aprendidos e com essa iniciativa um marceneiro já pediu ajuda para investir em madeira certificada. Porém, as ações de responsabilidade social ainda não repercutem de forma evidente em termos de mercado, pois, segundo Luciana, "melhorou o resultado de forma bem implícita". As mudanças internas "têm favorecido um melhor resultado da empresa".

As ações de responsabilidade social na empresa são desenvolvidas pelos gestores Luciana e Leôncio, porém a participação dos colaboradores é ativa. A divulgação das ações de responsabilidade social tem sido feita junto ao público interno, no sítio da internet da empresa e nos brindes de final de ano (foram enviados aos clientes brindes sustentáveis, como um porta cartões confeccionado em madeira certificada, com uma mensagem sobre a importância da preservação ambiental).

A empresa se sente valorizada no mercado pela sua postura e pelo comprometimento no desempenho de seu trabalho e acredita que o engajamento de outras empresas a implementarem conceitos de responsabilidade social na sua gestão pode ser conquistado por meio de movimentos setoriais.

\section{Relacionamento com fornecedores}

A seleção dos fornecedores é feita pelas parcerias existentes há muitos anos, onde já existem valores construídos. Critérios como prazo e responsabilidade sobre o serviço a ser realizado também são fundamentais na escolha. A empresa está se organizando para ampliar e formalizar seus critérios de exigência, já que o Programa Tear mudou sua visão quanto aos critérios a serem adotados para seleção dos fornecedores em relação à responsabilidade social. A empresa pretende implantar algo semelhante ao contrato de prestação de serviços utilizado pela Y.Takaoka, onde uma série de critérios é listada para atendimento do conceito de responsabilidade social, como a proibição de trabalho infantil, a contribuição para as Metas do Milênio, entre outros. 
Os fornecedores atuais já são participantes no negócio, contribuem para bons resultados. São basicamente operários, fornecedores de itens de decoração, eletricistas, decoradores, cortinistas, marceneiros e pintores.

\section{Relacionamento com clientes}

Dos clientes atuais do escritório de arquitetura, apenas a Y.Takaoka faz exigências específicas com relação à responsabilidade social para a prestação de serviços. A empresa não julga difícil atender exigências como a rastreabilidade dos fornecedores envolvidos na prestação dos serviços, porém encontra dificuldades para encontrar materiais com o selo Forest Stewardship Council - FSC.

A empresa acredita ser possível o convencimento de seus clientes para a adoção de ações de responsabilidade social, mesmo com sua "pequena influência", abordando o cliente com a apresentação de soluções sustentáveis para os projetos. $O$ trabalho de conscientização dos clientes é feito também pela divulgação dos conceitos de sustentabilidade, na tentativa de ampliar sua visão que, "aos poucos, passam a demandar soluções mais sustentáveis".

O "espaço sustentável" montado pela empresa na exposição CAD BRASIL 2007 Casa Arte e Design é um exemplo de como uma iniciativa pode disseminar o conceito de responsabilidade social, já que o espaço, um lounge para banheiros públicos sustentável, foi pauta de uma reportagem da Rádio CBN e atingiu todo o público visitante da exposição.

Em relação à melhoria das ações de responsabilidade social por parte das incorporadoras/construtoras, a empresa sugere uma melhoria nas relações de parcerias com pequenos escritórios de arquitetura, favorecendo a política de negociações justas e repassando aos pequenos escritórios o capital necessário para melhoria dos processos internos, "já que para isso é necessário tempo, dinheiro e recursos humanos". Sugerem ainda uma melhoria nas políticas de concorrência entre as propostas, deixando mais claros os critérios relevantes de escolha e também um melhor planejamento para viabilizar prazos de entrega que favoreçam a qualidade dos projetos, já que custo e prazo são relevantes na escolha das empresas. 
Como sugestão para seus clientes incorporadores e construtores, a empresa identifica a questão ambiental como algo urgente a ser tratado, já que percebe que "os sistemas de gestão adotados nem sempre refletem as atividades desenvolvidas por seus clientes". E também julga a qualidade de vida dos colaboradores e prestadores de serviço das incorporadoras e construtoras como outro tema a ser abordado, já que "os prazos cada vez mais apertados para as atividades a serem realizadas tendem a inviabilizar cada vez mais ações nesse sentido".

\subsubsection{Empresa B}

O estudo da empresa B foi realizado por meio de entrevista nas instalações da empresa com a Eng ${ }^{a}$ Paula Baillot Lacerda, diretora da Alphageos Tecnologia Aplicada S.A., em 16 de abril de 2008.

\section{Caracterização da empresa estudada}

A empresa B é uma prestadora de serviços para engenharia na área de sondagens, fundada em 1985 e conta hoje com 120 colaboradores. Tem como principais atividades as sondagens a percussão, sondagens rotativas, televisamento $360^{\circ}$ das paredes de furo de sondagem, instrumentação, acompanhamento de obras subterrâneas, controle tecnológico de obras em solo e concreto, execução de concreto com fibras, poços de monitoramento para descontaminação, amostra de águas subterrâneas, gestão ambiental, inspeção de materiais de construção, auditoria tecnológica global, supervisão de obras e serviços especiais.

Os serviços são prestados diretamente aos proprietários dos empreendimentos a serem construídos ou ainda às construtoras, e em diversos momentos ao longo da linha de tempo da obra.

Atualmente está investindo no aprimoramento da auditoria tecnológica global, buscando adequar seus serviços às necessidades do mercado.

A empresa é acreditada pelo Instituto Nacional de Metrologia, Normalização e Qualidade Industrial (INMETRO) em mais de 90 atividades normalizadas pela Associação Brasileira de Normas Técnicas (ABNT) e ISO 17025. Até o final do ano a 
empresa se certificará segundo os referenciais das normas OHSAS 18001 e NBR ISO 14001.

\section{Responsabilidade social}

A empresa não conhecia o tema responsabilidade social antes da participação no Programa Tear, porém já adotava algumas práticas que se alinham ao conceito. Desde 1990, os operários da empresa são transportados em ônibus adaptados (retirada de alguns bancos para espaço para a carga e os demais bancos para os funcionários), ficam hospedados em hotéis e fazem suas refeições em restaurantes, diferente da maioria das empresas do mesmo ramo de atividade. Além disso, uma assistente social oferece suporte às famílias dos operários e a empresa sempre ofereceu cursos de alfabetização.

Em 1997, importou um equipamento para melhorar as condições de trabalho dos operários, que erguiam um equipamento de $60 \mathrm{~kg}$ repetitivamente ao longo do dia para realizar a sondagem. Atualmente é a única empresa que possui esse equipamento, que foi desenvolvido por mecânicos patrocinados pela empresa. A empresa enviou os mecânicos aos Estados Unidos para conhecerem 0 equipamento, se profissionalizarem e aprenderem a produzir o equipamento no Brasil.

Em sua realidade de negócio, a empresa acredita que os aspectos mais importantes a serem tratados na responsabilidade são as pessoas, para cuidar de seu bem estar respeitando o funcionário e sua família.

A empresa classifica a atuação das concorrentes em relação à responsabilidade social como nula, já que "estão bastante defasadas tanto por sua gestão como também por culpa dos contratantes", já que eles não fazem qualquer exigência quanto ao serviço prestado além dos resultados técnicos envolvidos. A empresa acredita que as grandes contratantes têm responsabilidade em elevar o nível da prestação de serviços. A própria empresa entrevistada passou pela experiência de elevar o nível de prestação de serviços quando a Companhia de Saneamento Básico do Estado de São Paulo (SABESP) exigiu a acreditação de seus serviços. 


\section{Programa Tear}

A empresa foi convidada pela Y.Takaoka a participar de uma palestra de apresentação do Programa Tear e se identificou imediatamente com o tema. Acredita que a participação no programa trouxe benefícios e muito aprendizado, disseminou a cultura e fez a empresa entender que no futuro a responsabilidade social pode se tornar um novo processo de certificação.

Alguns itens do programa são questionados pela empresa, que acredita que algumas ações não devem ser obrigatórias, e sim serem desenvolvidas pelo que a empresa julgue importante. Alguns itens dos Indicadores Ethos (por exemplo, contar quantos negros trabalham na empresa) e a própria adequação às Metas do Milênio são fatores que a empresa acredita que "têm pouco a agregar em sua gestão socialmente responsável, já que são muito abrangentes e distantes da realidade das empresas". Acham que o programa mostra-se um pouco "engessado" e algumas questões precisam ser melhoradas para uma próxima edição, como trabalhar melhor a liberdade das empresas fazerem o que realmente importa para sua realidade e não apenas seguir a metodologia.

O resultado do balanço social, por exemplo, não ficou como a empresa desejava, pois havia um prazo de apresentação em função dos cronogramas do Instituto Ethos.

Em relação à dedicação ao programa, algumas horas do trabalho e a participação nas reuniões mensais são suficientes, mas o fato da empresa não ter custo direto algum é algo bastante motivador.

A empresa acredita que o programa tem trazido muitos benefícios, incentivando inclusive o patrocínio de um livro em 2006 e a realização de sondagem de graça para um projeto institucional com os funcionários da empresa trabalhando como voluntários. Porém, apesar do grande envolvimento com o tema, ainda "falta caminhar muito", pois a questão da disseminação da responsabilidade social na empresa ainda é crítica. Foi feita uma tentativa de levar a cada mês uma pessoa da empresa às reuniões, mas isso não foi possível devido à estrutura bastante enxuta não permitir que um dos colaboradores se ausente por um dia todo de sua função. 
Em relação às ações do programa, a empresa já pensava em uma série delas, e na oportuna discussão afloraram outras idéias. O foco principal é dar ênfase ao público interno, para melhorar as famílias dessas pessoas. As ações ainda não "andam na velocidade desejada" por faltarem pessoas para operacionalização, mas existe a intenção de acompanhamento para que os filhos dos funcionários estejam na escola, garantindo a assiduidade e os resultados das notas, e em contrapartida ganhariam algo, porém ainda não há nada formalizado.

$\mathrm{Na}$ ocasião da entrevista, não havia um controle financeiro específico referente às ações de responsabilidade social. Em função da própria dificuldade em identificar os investimentos, pretendem implantar um centro de custos específico.

Analisando sua imagem no mercado, a empresa ainda não conseguiu perceber nenhuma diferença em termos competitivos, mas espera colher resultados mais pra frente. A Petrobrás, por exemplo, ficou satisfeita quando soube do investimento da empresa em responsabilidade social, o que demonstra um fortalecimento de sua imagem, mesmo não existindo ainda uma divulgação formal das ações de responsabilidade social pela empresa.

A abordagem que a empresa acredita ser eficaz no engajamento de empresas para investirem em responsabilidade social é algo bem próximo do modelo do Programa Tear, pois as diferentes empresas em grupo favorecem a troca de experiências inusitadas. Se todas as empresas participantes do programa fossem do mesmo segmento, traria mais riqueza em termos de fortalecimento do setor, pois difundiria melhor o conceito e forçaria o contratante a entender o problema. Por outro lado, a empresa acredita que com os concorrentes num mesmo grupo "você não poderia ser tão transparente em relação a sua própria atuação no mercado".

Se fosse mais focado ainda no setor da construção, seriam tratados os problemas específicos do setor, o que poderia gerar um maior interesse por parte dos participantes por se tratar de algo mais enriquecedor como negócio.

\section{Relacionamento com fornecedores}

A empresa não possui um critério formal para seleção dos fornecedores, mas já descobriu trabalho infantil na fábrica de um de seus fornecedores e o descredenciou. 
A empresa só trabalha com os melhores equipamentos disponíveis no mercado, e acaba atuando mais com o bom senso, e por trabalhar sempre com os mesmos fornecedores, procura investir em parcerias para evitar o trabalho de qualificação a cada compra.

O Programa Tear mudou alguns conceitos da empresa em relação aos fornecedores, porém o departamento de compras ainda não está alinhado com as intenções da diretoria, que pretende aos poucos envolver todos para discutir algo mais prático, formalizando seus critérios de seleção.

\section{Relacionamento com clientes}

Poucas empresas fazem exigências referentes à responsabilidade social, e as que fazem apenas solicitam informações apenas no preenchimento do cadastro. A empresa julga que esses critérios são necessários para criar barreiras da concorrência desleal de preços, já que algumas concorrentes não praticam nem o que é exigido por lei.

A empresa, sempre que possível, procura disseminar os conceitos de responsabilidade social a seus clientes, sempre comentando sobre o Programa Tear. Quando tem oportunidade apresenta o tema e usa o livro Ensaio de Helena, de Tatiana Piccardi, que foi patrocinado pela empresa, como uma porta de entrada do assunto.

A empresa acredita que, para melhoria das ações de responsabilidade social em relação aos seus fornecedores, as incorporadoras e construtoras deveriam entender o que é responsabilidade social, e inserir critérios de desempate entre os concorrentes nela baseados, o que atualmente não existe. As licitações deveriam ser mais transparentes, sem leilão apenas por preços e sim considerando a qualificação das empresas e suas práticas.

Ainda segundo a empresa, a construtora também é responsável por elevar o nível dos fornecedores, e tem isso como responsabilidade. Precisam de um trabalho interno para disseminar a cultura de elevar o nível do setor e dos fornecedores. Para isso, é necessário preparar melhor os departamentos de compras e suprimentos, já que atualmente essas áreas têm conhecimento restrito para comprar, tem 
dificuldade de especificar materiais e serviços e de equalizar propostas, o que resulta em um departamento que não tem condições de discernir as boas propostas.

Diante disso, a empresa acredita que o investimento em responsabilidade social ainda está muito distante para as construtoras, já que precisam primeiramente respeitar seus fornecedores e definir critérios melhores para qualificá-los, caso contrário não influenciam na melhoria do mercado.

Ações voltadas à educação, como os filhos dos funcionários nas escolas; ao meio ambiente, como a construtora manter a obra mais limpa e organizada, evitando o desperdício, destinando corretamente seus resíduos, consumo racional de água e energia, e a uma melhoria no relacionamento com fornecedores, como parcerias que poderiam ser criadas para realizar ações conjuntas de voluntariado, favorecendo relações comerciais sadias, são expectativas que a empresa tem para o mercado da construção civil.

\subsubsection{Empresa C}

O estudo da empresa $C$ foi realizado por meio de entrevista nas instalações da empresa com o $\mathrm{Eng}^{\circ}$ Daniel Ohuma, gerente de sustentabilidade do CTE - Centro de Tecnologia de Edificações, em 22 de abril de 2008.

\section{Caracterização da empresa estudada}

A empresa C, fundada em 1990, é uma prestadora de serviços no setor de construção civil, oferecendo consultoria empresarial nas áreas de estratégia, gestão de processos, tecnologia, qualidade, meio ambiente, segurança e responsabilidade social; sustentabilidade de empreendimentos, projetos e obras; gerenciamento de obras; estruturação de negócios imobiliários e; eventos, cursos e publicações. Conta atualmente com um quadro 60 colaboradores, e seu sistema de gestão é certificado pelas normas NBR ISO 9001, NBR ISO 14001 e OHSAS 18001. Pretende ampliar a sua atuação para a indústria de materiais, dentro ou fora do setor da construção civil.

A análise desse estudo foi realizada na unidade de negócios 'Sustentabilidade de Empreendimentos, Projetos e Obras'. 


\section{Responsabilidade social}

A unidade de negócios 'Sustentabilidade de Empreendimentos, Projetos e Obras' da empresa já conhecia os temas de responsabilidade social e sustentabilidade uma vez que atua com esses conceitos. Foi criada em 2003, e acredita que desde então a questão ambiental tem sido mais abordada no setor da construção civil. A concorrência tem se envolvido com o tema, tanto na divulgação como na realização de ações diversas.

\section{Programa Tear}

A empresa foi convidada a participar do Programa Tear, e aceitou o convite pelas seguintes razões: manter um bom relacionamento com seus clientes (Y.Takaoka/Gafisa), conhecer mais o assunto (encarando o Programa Tear como uma oportunidade de aprendizado) e entender a questão social na visão do Instituto Ethos.

Em relação à dinâmica do programa, acha que as reuniões são muito longas e dificultam a participação das empresas. Daniel também acha que "faltou mostrar mais onde as empresas poderiam chegar adotando a metodologia do Programa Tear" e o que poderia ter sido feito trazendo mais exemplos de empresas que já estão avançadas no tema. A duração do programa é longa, porém a empresa julga que um tempo muito curto também não mudaria a cultura dos participantes, o que acredita ser algo importante no programa.

Como principais benefícios pela participação no programa, a empresa identifica o aprofundamento do tema, ampliação do conhecimento e a troca de experiências.

A empresa ainda não consegue dedicar o tempo necessário para tratar o tema internamente. Existe um comitê de sustentabilidade do qual fazem parte representantes de todas as áreas da empresa, que se reúnem mensalmente por um período de quatro horas para tratar dos assuntos relacionados à responsabilidade social e sustentabilidade. Seriam necessárias ainda ao menos 4 horas por semana para complementar as ações, mas hoje ainda são dedicadas apenas 8 horas por mês. 
A participação no Programa Tear ainda não trouxe novos negócios em termos econômicos, mas nos aspectos social e ambiental, alterou a estrutura da empresa e influenciou as ações desenvolvidas, como por exemplo, o processo de gestão de pessoas estruturado no comitê de sustentabilidade. No entanto, o programa não forneceu subsídios para a criação das ações.

A empresa encontra-se muito envolvida com o tema da responsabilidade social, tanto na figura de sua diretoria, como também na disseminação da cultura. Questões como a certificação ambiental de edifícios Leadership in Energy and Environmental Design (LEED), estratégia de mercado, investidores, mercado e clientes são critérios decisivos na escolha das ações de responsabilidade social desenvolvidas pela empresa.

$\mathrm{Na}$ ocasião da entrevista, a empresa não promovia um controle financeiro específico para investimentos destinados às ações de responsabilidade social, porém a empresa pretende implantar algo que atenda essa necessidade, inclusive por demanda do relatório de Balanço Social a ser elaborado com base no Global Reporting Iniciative - GRI.

Os principais benefícios identificados pelo investimento em responsabilidade social são o incremento da credibilidade e imagem da empresa para o mercado, a conscientização da importância de administrar melhor os impactos gerados pelas atividades da empresa, foco na eficiência interna e valorizar mais o público interno.

As ações de responsabilidade social promovidas pela empresa são divulgadas atualmente pelo sítio da internet, via e-mail, pelo sistema eletrônico interno de comunicação e pretende-se montar um mural para divulgação das ações do comitê de responsabilidade social.

$\mathrm{Na}$ ocasião da entrevista, o comitê de responsabilidade social era o responsável pelas ações de responsabilidade social realizadas. Dentro do comitê foram definidas as atribuições de cada um dos participantes. A empresa cultiva a cultura da gestão participativa, onde todos se envolvem com tudo que é de uso comum. Um exemplo disso é a ampliação das instalações da empresa, onde todos puderam contribuir 
com sugestões e também com os conhecimentos técnicos nos projetos, focados no uso eficiente de recursos (energia, madeira, tintas).

Até o momento, a empresa identifica que a principal contribuição da implementação da responsabilidade social na gestão foi o aumento da preocupação do benefício para a sociedade, porém não conseguiu identificar ainda incremento nos resultados econômicos. Acredita também que o engajamento de outras empresas para investirem em responsabilidade social deve começar pelo convencimento da alta direção, já que sem seu o comprometimento, as ações tornam-se mais difíceis de serem realizadas.

\section{Relacionamento com fornecedores}

A empresa seleciona seus fornecedores com base nos critérios de análise de custo, prazo e qualidade. Justifica essa postura por uma visão de negócios, mas em função do Programa Tear, pretende ampliar os critérios analisando também a questão social e ambiental. Para isso, pretende desenvolver um questionário de qualificação dos fornecedores, a ser aplicado inclusive aos fornecedores de pequeno porte, como empresas de entrega de documentos, copiadoras e distribuidoras de produtos de limpeza.

Por ser uma empresa de consultoria, a empresa pretende "abrir suas portas para disseminar suas práticas". Essa nova visão vai alterar os critérios atuais de seleção, pois caso o fornecedor não atenda um dos critérios da qualificação, ele será avaliado para verificar seu alinhamento com as premissas da empresa. Caso o fornecedor tenha uma boa prática de responsabilidade social e tenha um produto ou serviço mais caro, ele será priorizado na concorrência.

\section{Relacionamento com clientes}

Apenas um cliente faz exigências específicas relacionadas a responsabilidade social em contrato.

A empresa pretende criar um mecanismo para conscientização de seus clientes no momento da contratação, como a criação de uma cartilha com "dicas" de boas 
práticas para o dia-a-dia em todas as propostas comerciais, além da divulgação do manifesto elaborado pela empresa e a divulgação das boas práticas.

Como sugestão para melhoria das ações de responsabilidade social para empresas incorporadoras/construtoras, o investimento em qualificação da mão-de-obra, educação e capacitação das microempresas, além de investimento na saúde são fundamentais.

A empresa acredita que questões como ética, valores e corrupção do setor deveriam ser discutidos de forma setorial, gerando um documento ou algo similar que expressasse como deveriam ser as relações entre os agentes, mas não acha que isso seria possível atualmente.

$\mathrm{Na}$ opinião da empresa estudada, a consolidação da responsabilidade social na atuação das empresas incorporadoras/construtoras depende de um consumidor mais exigente e consciente, que influencie as ações as empresas, e também depende do investimento na educação dentro do setor, para conscientização dos agentes da cadeia produtiva sobre a questão social. 


\section{ANÁLISE}

A partir das informações obtidas no estudo de caso do Programa Tear e nos estudos exploratórios da empresa âncora, Instituto Ethos e empresas participantes, esse capítulo apresenta as análises feitas buscando-se atender aos objetivos iniciais da pesquisa, que são a análise e avaliação da implementação do Programa Tear; a análise das dificuldades e impactos trazidos pela participação das empresas no programa e a proposição de diretrizes para inserção da responsabilidade social na gestão de empresas incorporadoras e construtoras em relação aos seus fornecedores.

A análise do Programa Tear traz a percepção da pesquisadora como observadora de sua implementação e, por conseqüência disso, parte das críticas apresentadas advêm dessa condição.

Para aprimorar a análise do Programa Tear, foram estudadas outras duas iniciativas setoriais que também apresentam metodologias de trabalho para capacitação de grupos de empresas. Os estudos exploratórios com essas duas experiências foram realizados antes da elaboração desse capítulo, o que não permitiu que todas as considerações feitas em relação ao Programa Tear pudessem ser comparadas aos programas estudados.

\subsection{Outras experiências de programas em grupos de empresas}

O objetivo do estudo exploratório de outros programas em grupos de empresas foi conhecer as dinâmicas utilizadas em cada um deles, de forma a identificar semelhanças e divergências com o Programa Tear e, dessa forma, buscar subsídios para sua análise. Foram identificadas duas experiências em grupos para capacitação de empresas. 


\subsubsection{Programa de Capacitação para Gestão da Qualidade no Desenvolvimento do Projeto na Construção Civil}

A primeira experiência em grupos para capacitação de empresas a ser estudada é o Programa de Capacitação para Gestão da Qualidade no Desenvolvimento do Projeto na Construção Civil. A Dra Maria Angélica Covelo Silva, coordenadora da iniciativa, concedeu uma entrevista baseada no questionário anexo (apêndice 1) no mês de julho de 2008.

Esse programa foi escolhido para ser estudado em função de sua originalidade na época em que foi promovido, permitindo analisar a evolução desse tipo de iniciativa no setor da construção civil e possibilitando também a análise quanto à dinâmica utilizada.

O objetivo desse programa foi desenvolver e validar com empresas de projeto e contratantes de projeto (incorporadoras e construtoras) uma metodologia adequada para a gestão da qualidade do processo completo de desenvolvimento de projeto de edificações. Como resultado dessa iniciativa, foi publicado em 2003 pela Editora $O$ Nome da Rosa o livro "Gestão do processo de projeto de edificações", que é uma síntese do material gerado ao longo do programa.

O Programa foi iniciado em 1997 e promovido pelo Sindicato da Indústria da Construção Civil de São Paulo (SindusCon-SP), Sindicato das Empresas de Compra, Venda, Locação e Administração de Imóveis Residenciais e Comerciais de São Paulo (Secovi-SP), Associação Brasileira dos Escritórios de Arquitetura (AsBEA), Associação Brasileira de Engenharia e Consultoria Estrutural (ABECE), Sindicato Nacional das Empresas de Arquitetura e Engenharia Consultiva de São Paulo (Sinaenco-SP) e pelo CTE - Centro de Tecnologia de Edificações, uma empresa privada de consultoria e capacitação profissional voltada ao setor da construção civil, e teve turmas em andamento até 2002.

A Dra Maria Angélica Covelo Silva teve o papel de desenvolver a metodologia e aplicá-la junto com o Dr. Roberto de Souza (diretor do CTE). Contou com uma equipe de apoio do CTE até 1998 e, posteriormente, deu seqüência ao programa com uma equipe do NGI - Núcleo de Gestão e Inovação, empresa fundada pela Dra 
Maria Angélica Covelo Silva em julho de 1998, com o intuito de prestar consultoria para o setor da construção civil.

Para escolha das empresas a serem convidadas para a iniciativa, as organizações participantes escolheram as primeiras 23 empresas, sendo 13 empresas de projeto de diversas especialidades (escolhidas pela AsBEA e pela $A B E C E$ ), das quais três eram de projeto de sistemas prediais, e 10 empresas incorporadoras e construtoras (metade indicada pelo SindusCon-SP e a outra metade pelo Secovi-SP). A partir daí abriram-se inscrições para as demais turmas cuja exigência era que fossem empresas de projeto de toda natureza, não importando o porte, porém associadas a uma das entidades promotoras. No ato da inscrição, as empresas eram informadas sobre a carga horária de dedicação do programa, da necessidade de dois participantes por empresa e das tarefas de implantação. A partir da segunda turma, as empresas de projeto e as incorporadoras e construtoras foram separadas em dois programas diferentes: um que se realizava na sede do Sinaenco e outro que se realizava na sede do SindusCon-SP. Além da primeira turma mista, outras 6 turmas de empresas de projeto em São Paulo participaram do programa, duas em Londrina/PR e uma em Porto Alegre/RS, além de mais duas turmas de empresas construtoras. Foram no total 113 empresas de projeto e 21 empresas de incorporação/construção participantes. Na primeira turma o programa durou 12 meses, e da segunda em diante a duração foi de 6 a 8 meses (seis meses para as construtoras e oito para as empresas de projeto), demonstrando um amadurecimento da aplicação da metodologia.

A dinâmica do programa era de um dia inteiro de trabalho a cada três semanas. Cada workshop (no total de 9 módulos) tinha um conteúdo específico, que abordava conceitos básicos de qualidade aplicados ao projeto, fluxo de atividades, organização da empresa, padronização e melhoria de processos, sistema de gestão da qualidade e plano de ação, melhoria e padronização de processos de gestão, concepção e entrega de projetos, e elaboração de manual da qualidade da empresa de projeto. A dinâmica respeitou a disponibilidade das empresas de não ter atividades toda semana e propiciava um dia de convivência e troca de experiências. O intervalo entre um e outro workshop permitia o tempo para a implantação necessária. 
Ao final de cada módulo aplicado em workshop específico, as empresas participantes tinham como compromisso realizar uma tarefa de implantação, onde os consultores que davam suporte ao programa visitavam as empresas para orientá-las no que fosse necessário. No módulo seguinte as empresas tinham que relatar o que fizeram, mas apresentaram um nível de comprometimento variado entre si.

Os resultados alcançados pelas empresas eram medidos por meio de avaliações quanto ao grau de implantação das ações propostas mediante as visitas dos consultores, juntamente com os relatos e o material que as empresas tinham que apresentar.

Os principais resultados alcançados relatados pelas empresas que efetivamente aproveitaram o programa envolveram três aspectos básicos, segundo a visão da $\mathrm{Dr}^{\mathrm{a}}$ Maria Angélica Covelo Silva:

1. Conseguiram ter uma visão do negócio e da empresa e da importância de um sistema de gestão, ampliando a visão restrita de ateliê/escritório técnico.

2. Conseguiram ter clareza dos processos que existiam dentro das empresas e dos que envolviam agentes externos, de modo a padronizá-los, criar rotinas e procedimentos. Com isso eliminaram ou estabeleceram controles de fontes de possíveis erros.

3. Para as empresas incorporadoras e construtoras, foi possível estabelecer o fluxo de atividades de todo o processo, discernir no que consistia verdadeiramente a coordenação e gerenciamento de projeto e estabelecer também procedimentos e controles.

Além disso, identificou-se ainda:

4. A complexidade no relacionamento entre projetistas e incorporadoras e construtoras era muito grande na época da realização do programa por falta de fluxo adequado de informações e falta de visão do processo como um todo, fazendo com que houvesse falta de definição de um fluxo lógico e falta de clareza nas responsabilidades. $O$ trabalho desenvolvido permitiu criar um fluxo mais claro, debater (intensamente) as necessidades de 
ambos os lados (empresas incorporadoras e construtoras e projetistas) e "foi mesmo um marco de início de mudanças na prática de desenvolvimento de projeto que se proliferou no mercado".

5. "A troca de informações e conhecimento levado aos participantes gerou vários aperfeiçoamentos às empresas que não sabiam como buscar certas melhorias, como controle de horas e formação do custo por exemplo, uso de normas técnicas etc.".

Eventuais antagonismos criados pelo fato de empresas concorrentes fazerem parte do mesmo grupo foram eliminados com o tempo, uma vez que algumas incorporadoras e construtoras já haviam criado o Comitê de Tecnologia e Qualidade e já vinham, desde 1994, promovendo ações para o desenvolvimento do setor. Por sua vez, as empresas de projeto passaram a trocar experiências percebendo que havia problemas e necessidades que não eram inerentes à atuação de cada uma individualmente, mas sim como um todo no setor, no processo de projeto. "Todas as turmas tiveram uma intensa troca de idéias e busca de soluções", afirma a Dra Maria Angélica Covelo Silva.

Para uma abordagem eficaz no engajamento de empresas para investirem em iniciativas setoriais, a $\mathrm{Dr}^{\mathrm{a}}$ Maria Angélica Covelo Silva acredita que devem ser levadas em conta três questões.

A primeira delas é a percepção e sensibilização das empresas para entenderem que aquele tipo de ação é maior que a atuação de cada empresa.

A segunda é a necessidade de se reunir empresas que tenham um mínimo de afinidade por tipo de atuação (no programa, algumas empresas associadas ao Sinaenco que atuavam em projetos de outras áreas como energia e saneamento em segmentos outros que o de edificações não se identificaram por completo com a realidade tratada no programa).

Finalmente, afirma que é preciso ter uma metodologia com forte embasamento conceitual e que seja ao mesmo tempo fortemente embasada na prática. No ensino de aspectos que afetam os processos das empresas quem está desenvolvendo a 
metodologia precisa conhecer muito como estes processos são desenvolvidos e usar uma metodologia adequada sob pena do total desinteresse dos participantes.

Segundo a Dr ${ }^{\mathrm{a}}$ Maria Angélica Covelo Silva, o modelo utilizado para o Programa de Qualidade em Empresas de Projeto pode ser amplamente utilizado para outros temas. No entanto, afirma que é preciso estruturar bem a metodologia, fazendo antes um grande diagnóstico e ouvindo as sugestões das empresas e pessoas envolvidas.

\subsubsection{Programa de Desenvolvimento Gerencial de Empresas de Projeto}

Outra experiência em grupos para capacitação de empresas é o Programa de Desenvolvimento Gerencial de Empresas de Projeto. O Professor Dr. Silvio Burrattino Melhado, da Escola Politécnica da USP, é o coordenador do programa e relatou a experiência por meio de entrevista baseada no questionário anexo (apêndice 1) em 17 de abril de 2008.

Esse programa, que tem como base a tese de doutorado de Otávio José de Oliveira (OLIVEIRA, 2005), foi escolhido para ser estudado em função das empresas abordadas serem todas fornecedoras do mesmo tipo de serviço (desenvolvimento de projetos), permitindo uma análise frente à experiência do Programa Tear com um grupo homogêneo de empresas.

O programa foi implementado pela primeira vez em março de 2006 por iniciativa do Departamento de Construção Civil da Escola Politécnica (PCC/USP), com dez empresas participantes e duração de um ano. Um novo grupo de empresas foi iniciado em julho de 2007, com término previsto para junho de 2008. Pretendia-se ainda montar um terceiro grupo, com enfoque na gestão da qualidade nas empresas de projeto. No mês de setembro de 2008, o Prof. Silvio Melhado informou que o programa com o segundo grupo foi finalizado em 20 de junho de 2008 e o terceiro grupo já havia sido iniciado.

O Prof. Silvio Melhado tem como papel a coordenação geral do programa, acompanhando-o de forma a manter o foco e orientar o andamento das atividades previstas. 
Para escolha das empresas participantes do programa, não há um critério formal pré-estabelecido, porém busca-se diversificar as especialidades de projetos diferentes para enriquecimento das discussões.

As empresas participantes têm alguns compromissos, formalizados com a assinatura de um termo de adesão, no qual se comprometem a respeitar o calendário proposto para as reuniões do programa e as visitas a serem realizadas nas empresas, e também a contribuir mensalmente para as despesas do grupo e para a realização do evento de encerramento do programa.

Após a formalização do compromisso das empresas com o programa, o grupo passa a se reunir mensalmente em encontros com duração de aproximadamente 5 horas para desenvolver as atividades necessárias. Como se trata de um programa de capacitação para uma melhor gestão das empresas de projeto, é necessária a disseminação dos conceitos de gestão, feita por meio de livros, slides, artigos e textos. Ainda são convidados profissionais externos para falarem sobre os conceitos de gestão, e periodicamente as empresas participantes são convidadas para apresentar seus casos implantados ao longo do programa, favorecendo a troca de experiências.

Segundo o Prof. Silvio Melhado, essa dinâmica favorece a reflexão dos participantes, com o objetivo de que as empresas apliquem o que é apresentado ao longo das reuniões da forma mais favorável à sua realidade. O conceito geral é a apresentação de um 'requisito', ou seja, algo que é importante para a gestão da empresa, e cada uma vai atendê-lo com a solução que julgar mais adequada.

No programa ainda são previstas visitas mensais de um representante da coordenação da iniciativa nomeado pelo Prof. Silvio Melhado às empresas participantes, onde é avaliada a aplicabilidade dos conceitos apresentados nas reuniões, os fatores que favoreceram ou prejudicaram a implantação das ações, etc. Esse representante é um pesquisador da linha de pesquisa "Gestão de Projetos" do departamento de Construção Civil da Escola Politécnica da USP (PCC-USP), em nível de mestrado ou de iniciação científica. Para coleta das informações necessárias, são aplicados questionários de diagnóstico e de análise de resultados para os diversos processos. 
O acompanhamento da evolução das empresas ao longo do programa é feito de forma qualitativa, comparando os diagnósticos feitos no início e no final do programa. Na sua primeira edição, o resultado mais evidente constatado foi o efeito multiplicador que ele provocou nas empresas. Em termos de aplicação dos conceitos apresentados, apenas uma das empresas participantes conseguiu implementar todos os conceitos de gestão apresentados.

Aqui também, para contornar o fato das empresas participantes do programa serem concorrentes, foi necessário um trabalho de conscientização de que as empresas no grupo são colaboradoras mútuas, mas em alguns casos disseminar a cultura de que as empresas não são adversárias foi mais difícil.

O coordenador do grupo, Prof. Silvio Melhado, acredita que o engajamento das empresas nesse tipo de iniciativa seria mais eficaz com a participação ativa das entidades setoriais no processo de capacitação das empresas e acredita que o modelo poderia ser replicado para a abordagem de outros assuntos, já que o mesmo foca a disseminação das melhores práticas em um determinado conceito, podendo, portanto, ser aplicável a outros temas.

\subsection{Análise do Programa Tear e propostas de melhorias}

A partir da bibliografia levantada e dos estudos de caso realizados, busca-se aqui evidenciar os pontos controversos existentes entre os objetivos e metodologia do Programa Tear e seus resultados, analisando seu desempenho e as dificuldades de sua implementação. Busca ainda analisar os ganhos das empresas participantes do programa e o quanto isso representa nos resultados das mesmas, e também a eficiência e deficiência das ferramentas utilizadas ao longo do programa.

O Programa Tear foi desenvolvido com o objetivo de aumentar a competitividade e a sustentabilidade de pequenas e médias empresas, ampliando suas oportunidades de negócio por meio da adoção de práticas de responsabilidade social aprendidas ao longo do mesmo. 
Para melhor entendimento, a análise aqui apresentada será feita conforme a metodologia do Programa Tear, já apresentada no capítulo 3.4. Também serão retomados para análise os objetivos iniciais do Programa Tear apresentados no capítulo 3.3. De forma a facilitar a citação dos programas setoriais estudados para análise do Programa Tear nesse capítulo, o Programa de Capacitação para Gestão da Qualidade no Processo de Projeto será renomeado como Programa para Gestão da Qualidade e será representado pela sigla PGQ, e o Programa de Desenvolvimento Gerencial de Empresas de Projeto será renomeado como Programa de Desenvolvimento Gerencial e será representado pela sigla PDG.

\section{A. INÍCIO DA CONSTRUÇÃO DA REDE E SENSIBILIZAÇÃO}

\section{A1. Definir o modelo do programa}

O modelo definido para o Programa Tear, nessa primeira edição, foi elaborado pelo Instituto Ethos juntamente com os demais participantes. Quanto à possibilidade de novas edições do programa, não ficou claro quais seriam as alternativas para outros modelos ou mesmo de que forma esses modelos poderiam ser criados para atender os requisitos da metodologia.

O programa realizado pelo Instituto Ethos teve duração de 3 anos, desde sua concepção junto às empresas âncoras até as reuniões com as empresas participantes (24 encontros). A sua duração pode de alguma forma ter prejudicado os resultados propostos, já que o intervalo de 1 mês entre as reuniões e a duração das mesmas (o dia todo) pode ter afetado o comprometimento e o rendimento das empresas com o programa (como apontado pelas empresas estudadas), já que a ausência dos dirigentes ou mesmo colaboradores da empresa de pequeno porte por um dia todo acaba prejudicando o andamento das atividades do cotidiano da empresa, o que as vezes impediu que algumas empresas participassem com mais assiduidade.

No caso do PGQ, o intervalo entre as reuniões era de três semanas e os encontros duravam o dia todo. No caso do PDG, os encontros aconteciam mensalmente e duravam aproximadamente 5 horas, sendo que no primeiro grupo os encontros foram realizados aos sábados a fim de evitar a ausência dos participantes na 
empresa durante a semana. Dessa forma, o intervalo entre as reuniões e a duração das mesmas deveria ser uma decisão a ser tomada considerando a opinião das empresas participantes, a fim de atender suas reais necessidades.

Seria necessário ainda um acompanhamento mais próximo de todas as atividades propostas ao longo do programa para garantir um melhor aproveitamento das empresas participantes. Para isso, as empresas poderiam ter um tipo de bonificação ou incentivo para entregar as tarefas nos prazos, já que aquelas que não o fazem prejudicam o andamento do grupo e acabam não dando subsídios necessários para os condutores do programa quanto ao seu andamento (se o ritmo pode ser acelerado ou precisa ser atrasado).

No caso do PGQ, ao final de cada módulo as empresas tinham como compromisso a realização de uma tarefa de implementação do assunto tratado. Já no PDG, acontecia uma visita mensal por parte da coordenação do programa para acompanhamento das atividades a serem realizadas. Caberia dessa forma uma melhoria no acompanhamento das empresas para a obtenção de melhores resultados.

\section{A2. Formalizar o compromisso com o programa}

A formalização do compromisso das empresas com o programa poderia ser mais exigente, uma vez que pelo fato de não existir contribuição financeira e por ser um programa promovido por um cliente, algumas empresas ao longo da metodologia passaram a considerar sua participação como "obrigação", sem considerar os ganhos em longo prazo. As empresas precisariam de um compromisso que as comprometesse mais com o programa, pois apenas a relação comercial com as empresas âncoras pode não ter sido suficiente. No caso dos outros programas setoriais de estrutura semelhante (como os apresentados nessa dissertação), houve contribuição financeira das empresas participantes, o que poderia aumentar a dedicação dos participantes, fazendo com que os resultados pudessem ser mais evidentes, porém essa é uma condição a ser verificada. 


\section{A3. Comprometer a equipe executora}

Casa empresa participante teve como compromisso inicial a definição de um representante para participação nas reuniões. Para o nivelamento entre as empresas e também para resultados mais homogêneos, poderia ter sido definido um perfil de representante da empresa a fim de auxiliar na disseminação posterior na empresa dos conceitos abordados nas reuniões e também na operacionalização das atividades propostas ao longo do programa, uma vez que um diretor de empresa participando do programa tem muito mais poder de decisão e de disseminação do que um estagiário que eventualmente represente a empresa nas reuniões. O tempo de empresa também interfere nos resultados, pois um representante com mais tempo de empresa (especialmente em empresas de pequeno porte) podem retratar melhor a realidade das atividades. No caso do PGQ, foi solicitada a presença de dois representantes das empresas para participação, mas em ambos, PGQ e PDG, não houve também um critério para definição do representante a participar das reuniões ao longo do programa, questão que pode ser melhorada.

\section{A4. Selecionar as empresas participantes (clientes e/ou fornecedores)}

Em relação à escolha das empresas para participação do programa, o setor da construção civil não foi representado de acordo com sua realidade, uma vez que alguns agentes de impacto nos problemas setoriais (como empresas fornecedoras de serviços especializados de execução - subempreiteiros) não estavam presentes, porém não se sabe ao certo se era intenção do Instituto Ethos representar o setor, ou mesmo se era de conhecimento do Ethos o perfil dos principais fornecedores da cadeia de valor. Diante disso, o critério de escolha das empresas poderia ter sido mais preciso e melhor definido pelo Instituto Ethos para que um resultado mais uniforme pudesse ser alcançado juntamente com as demais cadeias, buscando dessa forma um maior impacto no setor.

Além disso, a participação do agente indutor na cadeia da construção civil incorporação não trouxe a contribuição esperada, uma vez que a entidade não participou do programa do começo ao fim e, considerando sua condição de sindicato, pouco contribuiu para a disseminação do programa e dos conceitos de responsabilidade social empresarial. 


\section{A5. Formalizar o compromisso da rede com o programa}

As empresas fornecedoras convidadas a participarem do grupo não tinham compromissos financeiros ou qualquer prestação de contas para com as âncoras do grupo ou com o Instituto Ethos. Considerando todas as empresas participantes, algumas se identificaram com o tema e se engajaram ao longo do programa (como as três empresas escolhidas para os estudos exploratórios), outras se mantiveram no programa pela relação comercial com as âncoras, porém algumas empresas não deram continuidade. Talvez fosse necessário um fator de comprometimento maior, por meio de um acompanhamento mais próximo quanto ao cumprimento das atividades propostas ou mesmo com a contribuição financeira das participantes. No caso dos movimentos setoriais estudados, as empresas não tinham uma relação comercial com o organizador do programa e não foram conduzidas a participar do programa, o fizeram por iniciativa própria.

\section{A6. Sensibilizar a cadeia de valor}

Nessa fase, o grupo formado pelas empresas âncoras e os fornecedores participantes deveria divulgar publicamente seu compromisso com o programa e incentivar outras empresas da cadeia a conhecer os conceitos da responsabilidade social. No início do Programa Tear, ainda não havia sido definida a política quanto ao uso da marca Tear e também em relação à sua divulgação vinculada às empresas participantes, o que atrapalhou o processo de disseminação aos públicos com os quais as empresas se relacionam.

\section{B. SENSIBILIZAÇÃO E ANÁLISE DA SUSTENTABILIDADE DO NEGÓCIO}

\section{B1. Estabelecer compromissos e princípios de trabalho no grupo}

Os compromissos assumidos pelo grupo inicialmente poderiam ter sido mais enfatizados ao longo do programa para manter o foco e os objetivos de todos os participantes sempre alinhados, pois ao longo das reuniões, algumas empresas apresentaram um menor interesse pelo programa ou mesmo perderam o foco inicial.

Outra questão que prejudicou o programa foi o fato de não ter sido apresentado inicialmente um cenário mais concreto dos resultados que poderiam ser alcançados 
ao final dos 24 encontros propostos. Dessa forma, haveria um melhor entendimento das empresas participantes com relação ao que poderiam fazer ao longo do programa. Em alguns momentos, a impressão foi de que algumas empresas não conseguiam visualizar 0 resultado final, provocando 0 desinteresse dos participantes, que não tinham um objetivo final claro a ser alcançado.

No caso do $P G Q$, inicialmente as empresas foram informadas sobre a carga horária de dedicação do programa e das tarefas para implantação da metodologia proposta, de forma a deixar claros os objetivos a serem alcançados. Dessa forma, seria importante criar um mecanismo para demonstrar o que poderia ser alcançado pelas empresas, tarefa que ficará mais fácil numa segunda edição do programa.

\section{B2. Sensibilizar para a sustentabilidade}

$\mathrm{Na}$ fase de sensibilização para a sustentabilidade, exemplos mais próximos da realidade das pequenas e médias empresas participantes poderiam ter sido trazidos para que os resultados possíveis de serem alcançados fossem mais visíveis. Pesquisas poderiam ser apresentadas para justificar 0 investimento em responsabilidade social, para as empresas pensarem mais em termos de estratégia de negócio.

Em relação ao conceito de sustentabilidade, uma abordagem mais aprofundada do tema poderia ter ajudado no entendimento e na reflexão de cada empresa em relação a sua realidade e o elas realmente precisariam fazer para colocar em prática o conceito da responsabilidade social. O nível de conceituação pareceu ser um pouco alto para a realidade das empresas participantes, inclusive os termos utilizados para tal apresentação.

\section{B3. Analisar o negócio sob a ótica da sustentabilidade}

A matriz SWOT, ferramenta auxiliar na análise do negócio, não foi aplicada ao grupo inicialmente, o que pode ter prejudicado o entendimento das empresas quanto aos impactos da responsabilidade social no negócio em si, ficando o conceito compreendido num nível mais conceitual e menos empresarial. Esse fato pode ter prejudicado as empresas na hora de traduzir a responsabilidade social para a questão estratégica da empresa, pois uma vez identificadas as fraquezas e ameaças 
do negócio, as ações de responsabilidade social poderiam ser estrategicamente alinhadas a outras para suprir essas deficiências.

\section{B4. Mapear as partes interessadas}

O mapeamento das partes interessadas foi realizado por cada uma das empresas após a apresentação do conceito e exemplos conforme a metodologia do programa, porém elas não compartilharam seus resultados com as demais participantes, ficando subjetiva a interpretação de cada uma delas em relação ao conceito apresentado. Dessa forma, tornou-se mais difícil a compreensão do conceito e a identificação das partes interessadas, impedindo a troca de percepções e a correção de possíveis desvios do conceito central do que são as partes interessadas.

No PGQ e PDG, fazia parte do compromisso das empresas apresentarem ao demais participantes o desenvolvimento de suas tarefas, a fim de compartilhar os resultados e melhorar o desempenho do grupo como um todo.

\section{B5. Identificar o estágio de desenvolvimento em gestão sustentável}

A tabela apresentada para avaliação do estágio de desenvolvimento em gestão sustentável das empresas (tabela 9) é bastante genérica, o que não permitiu que as empresas participantes do programa pudessem se enquadrar em um estágio que realmente retratasse sua realidade, uma vez que a classificação é bastante ampla. Poderia ter sido proposta uma adequação dos estágios às realidades das empresas (considerando que são de pequeno e médio porte) por meio do desmembramento dos estágios da tabela, como forma de auxílio na compreensão do termo desenvolvimento sustentável .

\section{DIAGNÓSTICO DA GESTÃO SUSTENTÁVEL}

\section{C1. Aplicar os Indicadores Ethos}

As empresas puderam optar por responder os Indicadores Ethos ou ainda os Indicadores Ethos-Sebrae, recomendados para empresas de pequeno porte. A utilização dos Indicadores Ethos-Sebrae poderia ter sido uma premissa para um melhor alinhamento das idéias do grupo, facilitando dessa forma a análise 
comparativa dos resultados de cada empresa, já que os Indicadores Ethos possuem um nível de exigências maior, o que pode desmotivar pequenas empresas que os respondem. Outra questão importante a ser levantada é o impacto causado pelas ações desenvolvidas pela empresa ao longo do Programa Tear. Considerando que as empresas participantes conheciam pouco ou não conheciam o tema responsabilidade social, as ações desenvolvidas ao longo do programa foram de pequena escala. Essas ações pouco interferem no questionário dos Indicadores Ethos, não gerando, portanto, grandes diferenças entre os indicadores do início e final do programa, o que pode gerar certa frustração nas empresas participantes, já que as ações desenvolvidas nem sempre refletem um resultado quantitativo que influencie nas notas dos indicadores.

\section{C2. Efetuar análise qualitativa das práticas de RSE na empresa}

Uma série de ferramentas foi apresentada às empresas (como as Metas do Milênio e a Matriz de Critérios Essenciais, por exemplo), mas o reflexo delas nas ações desenvolvidas pelas empresas foi pequeno. Como as empresas não utilizavam o conceito de responsabilidade social em sua gestão anteriormente, começaram por ações básicas (como a coleta seletiva e utilização de material reciclado), fazendo com que as ferramentas propostas ficassem muito distantes das suas realidades. Sugere-se que essas ferramentas sejam utilizadas apenas num estágio mais avançado de compreensão do tema por parte das empresas, possibilitando um melhor aproveitamento e também melhores possibilidades de aplicação.

\section{PLANOS DE AÇÃO}

\section{D1. Priorizar metas}

As metas priorizadas pelas empresas não tiveram um critério uniforme, já que não houve uma discussão em conjunto para definição de critérios que poderiam ser adotados por todas elas. As mesmas ações feitas por várias empresas permitiriam um grau de amadurecimento maior e um nível de resultados melhor.

No caso dos PGQ e PDG, os objetivos e metas eram mais claros, pois as empresas deveriam apresentar resultados em todas as etapas do processo, o que gera um resultado mais proveitoso, pois podem trocar experiências e melhorar suas práticas. 


\section{D2. Correlacionar metas com fatores críticos do negócio}

Essa etapa previa novamente uma leitura da matriz SWOT frente às metas definidas, para promover uma análise de alinhamento estratégico entre o que é necessário fazer e o que se pretende fazer. Na cadeia da construção civil incorporação, a análise SWOT proposta pelo Programa Tear só foi feita no início da segunda rodada da metodologia. Essa decisão pode ter comprometido o possível alinhamento entre as ações do plano de ação e os fatores críticos do negócio de cada empresa participante. Se em sua matriz SWOT a empresa identificasse que um ponto fraco é a retenção de colaboradores, por exemplo, um dos pontos a ser trabalhado na metodologia Tear seria necessariamente o público interno.

\section{D3. Analisar o estudo da sustentabilidade da cadeia e do setor}

Durante o desenvolvimento do Programa Tear, foi formado um grupo de profissionais convidados pelo Instituto Ethos para avaliação do estudo da sustentabilidade da cadeia e do setor por ele encomendado a uma empresa de consultoria. Na ocasião de avaliação do estudo, o mesmo apresentou-se fraco, com conteúdo pouco relevante para o seu propósito. Após a primeira avaliação, não foi realizada a revisão do estudo e os participantes do programa não puderam contar com essa ferramenta para orientar seus planos de ação. Essa era uma ferramenta importante para alinhar as ações das empresas às necessidades do setor, possibilitando um maior efeito não só internamente como também por meio de parcerias para promoção de tais ações. $O$ agente indutor da cadeia deixou de participar das reuniões após a apresentação do estudo do setor.

\section{D4. Elaborar planos de ação}

Os planos de ação foram elaborados pelas empresas internamente, com base nas informações obtidas por meio das ferramentas propostas ao longo do Programa Tear. Não houve um critério claro para a avaliação dos mesmos e orientação quanto a possível realização ou não das ações propostas, o que poderia ter auxiliado as empresas na escolha das prioridades a serem trabalhadas.

No PGQ e PDG, as ações desenvolvidas deveriam seguir os temas apresentados ao longo do programa, ficando mais fácil dessa forma o acompanhamento da evolução 
das empresas e também o alinhamento estratégico para troca de experiências e benchmarking.

\section{D5. Implementar e monitorar planos de ação}

A implementação das ações pelas empresas e o monitoramento foi feito ao longo das reuniões. Eventualmente, cada empresa fazia uma apresentação durante a reunião mensal, comentando sobre as dificuldades para implantar as ações e também os resultados gerados. Não houve um acompanhamento efetivo do cumprimento da elaboração dos planos de ação e da efetiva implementação pelas empresas.

Recomenda-se que, como metodologia do PGQ e PDG, sejam realizadas visitas periódicas para acompanhamento da implementação das ações. O Programa Tear disponibiliza sessenta e quatro horas de consultoria para acompanhamento das empresas, porém as visitas são realizadas conforme solicitação e não com uma programação pré-estabelecida.

\section{E. COMUNICAÇÃO E RELATÓRIO}

\section{E1. Elaborar o Balanço Social}

Foi estipulado um prazo para elaboração do balanço social, que deveria retratar as

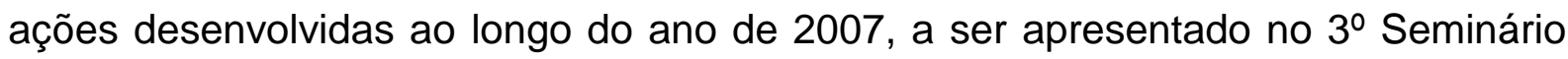
Regional do Programa Tear no mês de abril de 2008. No entanto, nem todas as empresas participantes cumpriram o prazo estipulado, já que não desenvolveram suas ações e não concluíram o balanço social a tempo. Esse é um indicador importante de eficiência do programa que não foi satisfatoriamente atingido. Da cadeia de incorporação da construção civil, apenas nove das dezoito empresas participantes apresentaram seu balanço social no prazo estabelecido.

\section{E2. Validar Balanço Social}

O processo de validação do balanço social com as partes interessadas envolvidas nos negócios das empresas participantes não foi claro e acabou não sendo 
realizado pelas empresas, o que comprometeu a etapa da metodologia do Programa Tear.

\section{F. CONSOLIDAÇÃO DA REDE (CONSTANTE)}

\section{F1. Fortalecer as relações entre os participantes da rede}

O fortalecimento foi promovido entre os participantes da rede, porém não foi desenvolvida nenhuma ação entre todas as empresas. Algumas se associaram para realizar projetos em parceria e outras indicaram empresas para realização de alguns trabalhos. Pelo fato das empresas não executarem as mesmas atividades, as ações em conjunto ficam mais restritas.

\section{F2. Incorporar práticas do programa na gestão}

A incorporação das práticas tem acontecido nas empresas participantes de forma gradativa, conforme as prioridades identificadas ao longo da metodologia do Programa Tear. A efetiva adoção dessas práticas só poderá ser verificada após certo período do término do programa, onde as empresas estarão agindo por conta própria, porém não há perspectivas de uma nova avaliação para medição desses resultados por parte do Instituto Ethos ou das empresas âncoras.

\section{G. EXPANSÃO DA REDE}

\section{G1. Aplicar a metodologia Tear em novos grupos}

O Programa Tear foi desenvolvido de forma a ser replicado posteriormente por cada uma das empresas participantes, propagando a responsabilidade social pelo efeito em cadeia.

Para que as empresas participantes pudessem se tornar âncoras seguindo a metodologia do Programa Tear, algumas questões deveriam ser esclarecidas:

- recursos necessários: os recursos mínimos necessários para que uma empresa de pequeno e médio porte possa promover o programa com sua cadeia de fornecedores poderiam ser levantados para facilitar a análise das empresas para esse tipo de decisão. 
- Conhecimento do tema: a empresas não têm as mesmas condições de tratar do tema responsabilidade social como fizeram os representantes do Ethos e as consultorias contratadas. Poderia ser criado um curso de capacitação de multiplicadores do Programa Tear para facilitar a disseminação da metodologia.

- Meios de convencimento para participação de novas empresas: o Instituto Ethos, como autor do programa, poderia sugerir um critério para convidar as empresas da cadeia de cada uma das participantes para dar seqüência à metodologia, numa segunda experiência, após promoção de melhorias da primeira.

- Estudo do setor: o estudo do setor poderia facilitar o processo de alinhamento estratégico entre as ações a serem promovidas pelas empresas e as reais necessidades do setor. Nesse sentido, as entidades participantes do programa (agentes indutores) precisam ter um papel mais ativo para auxiliar nesse processo ou mesmo se tornarem as "âncoras" no processo de disseminação da responsabilidade social.

\subsection{Análise quanto aos referenciais normativos}

Considerando os temas abordados no Programa Tear e os referenciais normativos apresentados nessa pesquisa, as empresas participantes não atingiriam os padrões exigidos para serem certificadas seguindo apenas a metodologia do programa. Seguem abaixo as análises de cada um dos referenciais, buscando apresentar os requisitos de cada um deles correlacionados ao que foi desenvolvido ao longo do Programa Tear.

\section{SA 8000}

O referencial normativo $S A 8000$ trata do atendimento a nove requisitos, aos quais o Programa Tear só atenderia caso esses requisitos fizessem parte dos planos de ação das empresas participantes, uma vez que trabalhar para evitar o trabalho infantil e o trabalho forçado, garantir a segurança e saúde no trabalho e a liberdade de associação e direitos coletivos, não praticar nenhum tipo de discriminação e 
práticas disciplinares, respeitar a carga horária de trabalho, garantir uma remuneração justa e investir em um sistema de gestão são ações implícitas do programa, porém não são uma exigência explícita.

Portanto, para uma certificação na norma $S A$ 8000, as empresas participantes precisariam focar suas ações para atendimento dos requisitos que o referencial apresenta.

\section{AA 1000}

Com relação ao referencial normativo $A A$ 1000, o Programa Tear atende os requisitos conforme descrito na tabela 10 .

Tabela 10 - Atendimento aos requisitos da $A A 1000$ pelo Programa Tear

\begin{tabular}{|c|c|c|}
\hline REQUISITOS AA 1000 & $\begin{array}{l}\text { ATENDIDO } \\
\text { PELO TEAR? }\end{array}$ & JUSTIFICATIVA \\
\hline $\begin{array}{l}\text { Estabelecimento de procedimentos de } \\
\text { engajamento e governança }\end{array}$ & Em partes & $\begin{array}{c}\text { As empresas que elaboraram o código de conduta } \\
\text { conseguem atender a esse requisito }\end{array}$ \\
\hline Identificação das partes interessadas & Sim & $\begin{array}{c}\text { O item B4 da metodologia do Programa Tear faz essa } \\
\text { exigência }\end{array}$ \\
\hline Definição/revisão de valores da organização & Sim & $\begin{array}{l}\text { Faz parte da metodologia do Programa Tear a } \\
\text { definição de missão, visão e valores da empresa }\end{array}$ \\
\hline $\begin{array}{l}\text { Identificação de temas críticos junto às } \\
\text { partes interessadas }\end{array}$ & Não & $\begin{array}{c}\text { Apenas a identificação das partes interessadas não } \\
\text { caracteriza os temas críticos }\end{array}$ \\
\hline $\begin{array}{l}\text { Determinação do escopo do processo } \\
\text { (unidades operacionais e questões a serem } \\
\text { incluídas, como considerar as partes } \\
\text { interessadas, prazo do ciclo atual, método } \\
\text { de auditoria, escopo da auditoria e auditor) }\end{array}$ & Em partes & $\begin{array}{l}\text { Quando a empresa define as partes interessadas a } \\
\text { serem trabalhadas, está delimitando o escopo do } \\
\text { processo de responsabilidade social }\end{array}$ \\
\hline $\begin{array}{l}\text { Identificação de indicadores (indicadores } \\
\text { sociais e éticos para avaliar desempenho da } \\
\text { organização em relação a seus valores e } \\
\text { objetivos; os valores e aspirações de suas } \\
\text { partes interessadas) }\end{array}$ & Sim & $\begin{array}{l}\text { Aplicação dos Indicadores Ethos de Responsabilidade } \\
\text { Social }\end{array}$ \\
\hline $\begin{array}{l}\text { Coleta de informações (sobre seu } \\
\text { desempenho em relação aos indicadores } \\
\text { identificados) }\end{array}$ & $\operatorname{Sim}$ & $\begin{array}{l}\text { Os Indicadores Ethos fornecem resultados que } \\
\text { orientam as ações a serem desenvolvidas }\end{array}$ \\
\hline $\begin{array}{c}\text { Análise das informações, estabelecimento } \\
\text { metas e desenvolvimento do plano de } \\
\text { melhoria }\end{array}$ & $\operatorname{Sim}$ & Análise das informações dos Indicadores Ethos \\
\hline Preparação do relato social & $\operatorname{Sim}$ & $\begin{array}{l}\text { A metodologia prevê que após a implantação do plano } \\
\text { de ação, seja elaborado o Balanço Social }\end{array}$ \\
\hline Auditoria do relato social & Não & $\begin{array}{c}\text { Não há a validação do Balanço Social junto às partes } \\
\text { interessadas }\end{array}$ \\
\hline $\begin{array}{c}\text { Comunicação do relato e obtenção de } \\
\text { retorno }\end{array}$ & Em partes & $\begin{array}{l}\text { O balanço social é comunicado, porém não há } \\
\text { retroalimentação pelas partes interessadas }\end{array}$ \\
\hline $\begin{array}{c}\text { Estabelecimento e integração de sistemas } \\
\text { (estabelecimento de sistemas para apoiar o } \\
\text { processo e o alcance contínuo de seus } \\
\text { objetivos e metas alinhados com seus } \\
\text { valores) }\end{array}$ & Em partes & $\begin{array}{l}\text { A melhoria contínua não é claramente promovida pelo } \\
\text { Programa Tear, uma vez que as próprias empresas } \\
\text { serão encarregadas de promover a revisão das ações } \\
\text { implementadas, porém sem nenhuma orientação por } \\
\text { parte do programa em relação a periodicidade }\end{array}$ \\
\hline
\end{tabular}




\section{SD 21000}

\section{Com relação ao referencial normativo SD 21000, o Programa Tear atende os requisitos conforme descrito na tabela 11.}

Tabela 11 - Atendimento aos requisitos da SD 21000 pelo Programa Tear

\begin{tabular}{|c|c|c|}
\hline REQUISITOS SD 21000 & $\begin{array}{l}\text { ATENDIDO } \\
\text { PELO TEAR? }\end{array}$ & JUSTIFICATIVA \\
\hline Papel da alta direção & Em partes & $\begin{array}{l}\text { O Programa Tear não exige claramente que o papel da } \\
\text { alta direção seja definido para desenvolvimento da } \\
\text { metodologia }\end{array}$ \\
\hline Desenvolvimento do sistema de governança & Em partes & $\begin{array}{l}\text { As empresas que desenvolveram o código de conduta } \\
\text { podem dar início ao sistema de governança }\end{array}$ \\
\hline $\begin{array}{l}\text { Comprometimento e envolvimento da alta } \\
\text { direção }\end{array}$ & Em partes & $\begin{array}{l}\text { Como o Programa Tear não exige claramente o } \\
\text { comprometimento da alta direção, mesmo sendo essa } \\
\text { condição importante }\end{array}$ \\
\hline Definição do plano de ação & Sim & $\begin{array}{c}\text { O plano de ação faz parte da metodologia do } \\
\text { Programa Tear }\end{array}$ \\
\hline $\begin{array}{l}\text { Programa do plano de ação para um período } \\
\text { de três a cinco anos }\end{array}$ & Não & $\begin{array}{c}\text { O Programa Tear não especifica qual o prazo para o } \\
\text { plano de ação }\end{array}$ \\
\hline Estruturação do plano inicial & Sim & $\begin{array}{l}\text { Inicialmente, o Programa Tear sugere a elaboração de } \\
\text { um plano inicial para um posterior alinhamento das } \\
\text { ações que efetivamente serão implementadas }\end{array}$ \\
\hline Plano final & Sim & $\begin{array}{c}\text { O plano de ação final é definido após análise e } \\
\text { validação do plano inicial }\end{array}$ \\
\hline $\begin{array}{l}\text { Monitoramento e a mensuração dos } \\
\text { impactos significativos }\end{array}$ & Em partes & $\begin{array}{l}\text { Não há nada explícito na metodologia que exija o } \\
\text { monitoramento e mensuração, mas os Indicadores } \\
\text { Ethos podem promover essa análise de forma nem } \\
\text { sempre satisfatória em função de sua } \\
\text { incompatibilidade com a realidade das pequenas e } \\
\text { médias empresas }\end{array}$ \\
\hline Indicadores de desenvolvimento sustentável & Em partes & $\begin{array}{l}\text { Os Indicadores Ethos podem fazer o papel de } \\
\text { indicadores de desenvolvimento sustentável }\end{array}$ \\
\hline Análise crítica & Em partes & $\begin{array}{l}\text { O Programa Tear não prevê a análise crítica como } \\
\text { parte da metodologia, mas ela é implicitamente } \\
\text { necessária para o bom andamento das ações }\end{array}$ \\
\hline Melhoria contínua & Em partes & $\begin{array}{c}\text { O Programa Tear não prevê a melhoria contínua como } \\
\text { parte da metodologia, mas ela também é } \\
\text { implicitamente necessária para os possíveis ajustes } \\
\text { nas ações }\end{array}$ \\
\hline Dimensão cultural das adaptações & Não & O Programa Tear não menciona a dimensão cultural \\
\hline Gestão de infra-estruturas e equipamentos & Não & $\begin{array}{l}\text { O Programa Tear não menciona a gestão de infra- } \\
\text { estrutura e equipamentos }\end{array}$ \\
\hline Projeto de produtos e serviços & Não & $\begin{array}{l}\text { O Programa Tear não menciona o projeto de produtos } \\
\text { e serviços }\end{array}$ \\
\hline $\begin{array}{l}\text { Gestão de suprimentos, subcontratados e } \\
\text { parceiros }\end{array}$ & Em partes & $\begin{array}{l}\text { Quando o programa se refere a partes interessadas, } \\
\text { implicitamente está considerando a gestão de } \\
\text { suprimentos, subcontratados e parceiros }\end{array}$ \\
\hline Gestão da informação e comunicação & Não & $\begin{array}{l}\text { O Programa Tear não menciona a gestão da } \\
\text { informação e comunicação }\end{array}$ \\
\hline
\end{tabular}




\section{NBR 16001}

Com relação à norma NBR 16001, o Programa Tear atende os requisitos conforme descrito na tabela 12.

Tabela 12 - Atendimento aos requisitos da NBR 16001 pelo Programa Tear

\begin{tabular}{|c|c|c|}
\hline REQUISITOS NBR 16001 & $\begin{array}{l}\text { ATENDIDO } \\
\text { PELO TEAR? }\end{array}$ & JUSTIFICATIVA \\
\hline Requisitos gerais & $\overline{\text { Não }}$ & Os requisitos gerais se referem aos da NBR 16001 \\
\hline Implementação e operação & Sim & $\begin{array}{c}\text { A implementação e operação das ações dependem do } \\
\text { que foi definido no plano de ação }\end{array}$ \\
\hline
\end{tabular}

ISO 26000

Em função da norma ISO 26000 não estar publicada, essa pesquisa não promoverá a análise comparativa pela ausência de informações suficientes.

\subsection{Dificuldades, impactos e diretrizes para fornecedores}

Diante dos relatos apresentados nos estudos realizados com as três empresas participantes do Programa Tear, alguns aspectos puderam ser levantados. A análise aqui apresentada é em parte especulativa, uma vez que apenas três das dezoito empresas participantes foram estudadas.

As três empresas estudadas apresentaram dificuldades para abordar todas as partes interessadas em seus planos de ação. As ações desenvolvidas, mais voltadas para o público interno e meio ambiente, demonstram o estágio inicial de envolvimento com o tema responsabilidade social, uma vez que essas duas partes interessadas 
(público interno e meio ambiente) demandam ações mais concretas e menos elaboradas, como a implantação de coleta seletiva e a valorização dos colaboradores por meio de premiações e reconhecimento pelas atividades desempenhadas. As demais partes interessadas (fornecedores, clientes, comunidade, governo e sociedade) ficaram em um segundo plano, pelo fato de demandarem ações mais elaboradas, a serem desenvolvidas quando as empresas atingirem um estágio de cumprimento básico de requisitos socialmente responsáveis e amadurecerem sua atuação em relação ao tema.

Quanto à dedicação ao Programa Tear, é um consenso que a duração das reuniões (o dia todo) é um fator que atrapalha a participação, pois é um período longo em que os representantes das empresas ficam ausentes de suas atividades.

Outro fato trazido pelos estudos é que as empresas julgam pequeno seu poder de influência sobre seus clientes e acreditam ser difícil a disseminação da responsabilidade social nesse âmbito, uma vez que algumas ações necessitam investimento, e um dos critérios mais fortes de decisão dos clientes entre um fornecedor e outro é o preço, que rotula as empresas fazendo com que seus diferenciais de responsabilidade social sejam pouco valorizados.

Foi mencionado também nos estudos que a estrutura do Programa Tear apresentase bastante rígida e em alguns momentos pode dificultar a aplicação de todas as ferramentas propostas por parte das empresas.

A dificuldade de colocar a responsabilidade social no dia-a-dia da empresa foi algo mencionado por todas as empresas, pois no início é necessária uma dedicação exclusiva para que as ações comecem a ser implantadas e passem a funcionar de forma natural.

Uma falha apontada pelas empresas na metodologia do Programa Tear foi a falta de esclarecimento em relação aos resultados que poderiam ser alcançados pela participação nas atividades previstas na metodologia, o que gerou certa instabilidade ao longo dos encontros propostos.

Uma grande dificuldade encontrada pelas empresas foi a questão da disseminação dos conceitos adquiridos ao longo do programa. Durante as reuniões, o ambiente é 
mais favorável para o aprendizado e compreensão de novos conceitos, uma vez que todos os participantes estão juntos em busca de um propósito comum e contam com a consultoria de profissionais que auxiliam na disseminação dos conteúdos propostos. No entanto, quando cada um dos representantes das empresas volta para seu cotidiano e tenta disseminar o que vivenciou nas reuniões, a magnitude do conteúdo não é mais a mesma, o que gerou inclusive um pouco de frustração dos participantes, pois não conseguiram repassar por completo tudo o que vivenciaram.

Ainda nesse sentido, outra dificuldade apontada é a questão da capacitação dos colaboradores das empresas, uma vez que o sucesso na implantação das ações sugeridas ao longo do programa depende muito da colaboração e do empenho dos funcionários envolvidos, especialmente na compreensão da importância do que está sendo tratado.

Com relação aos impactos decorrentes da participação no programa, as empresas identificaram como o mais relevante a questão da conscientização com relação à responsabilidade social e o conhecimento adquirido, mas acreditam que os resultados serão percebidos mais em longo prazo. Não identificaram porém o ganho de competitividade previsto nos objetivos do Instituto Ethos em relação ao Programa Tear.

\section{Análise geral das empresas participantes}

Em uma das reuniões do Programa Tear (16 de junho de 2008), estavam reunidas as duas cadeias da construção civil: grandes obras e incorporação. Nessa ocasião, foi proposta uma pesquisa para avaliar o resultado da participação das empresas no programa. Essa pesquisa foi realizada com base nos objetivos iniciais do Programa Tear, propondo aos participantes a escolha entre as seguintes alternativas para classificar cada um dos objetivos: não aconteceu, aconteceu de forma discreta, aconteceu de forma mediana e aconteceu de forma efetiva. Todas as empresas presentes responderam a pesquisa, conforme o modelo do apêndice 5 . Os resultados estão apresentados na figura 11. 


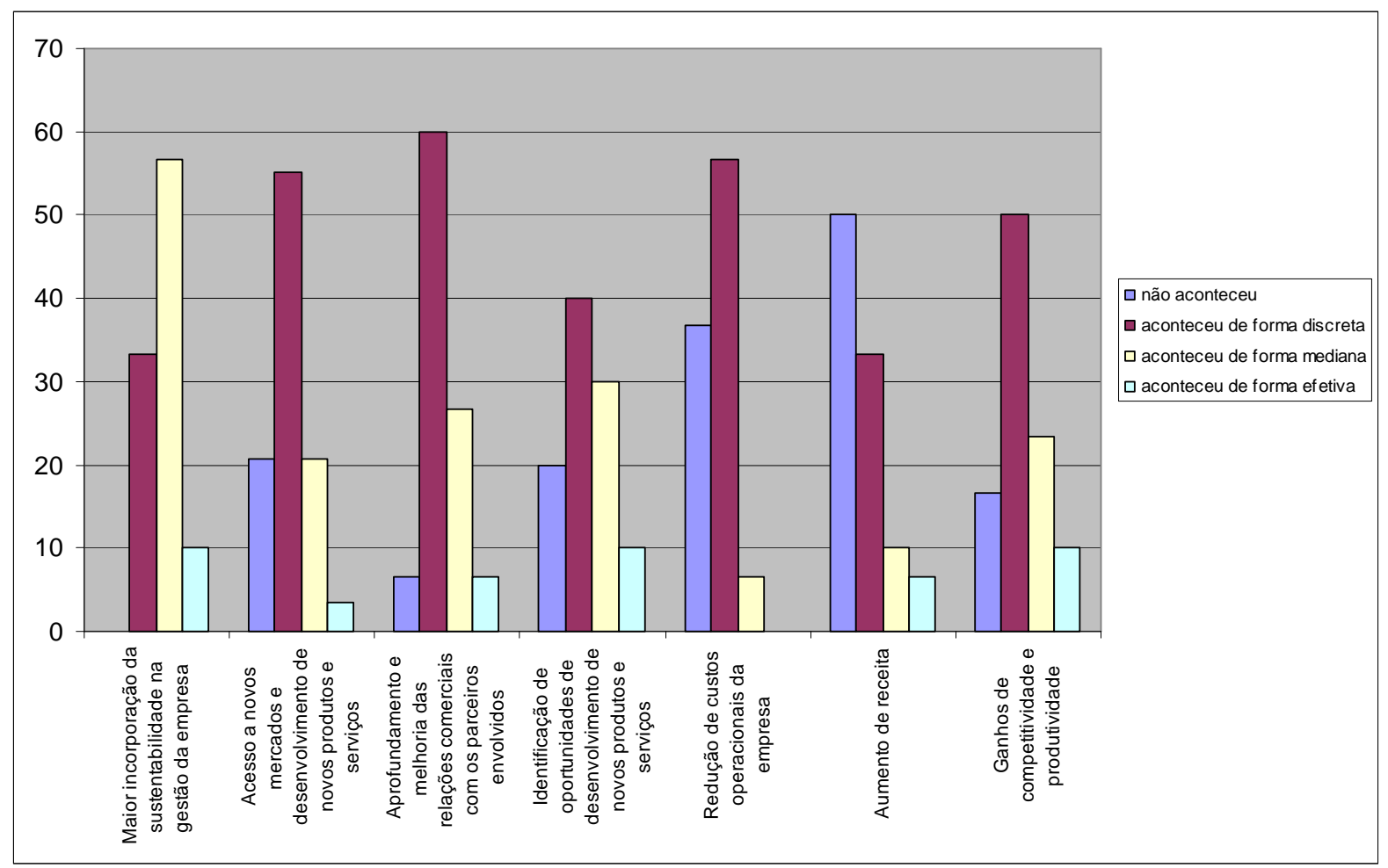

Figura 11 - Respostas dos participantes em relação aos objetivos do Programa Tear

A figura 11 demonstra que, de maneira geral, as empresas perceberam uma mudança de discreta a mediana em sua gestão ao participarem do Programa Tear. Considera-se nessa análise que alguns impactos só poderão ser percebidos ao longo do tempo, resultantes da conscientização dos líderes das empresas participantes e da continuidade das ações iniciadas. Porém, aspectos como a redução de custos operacionais e o aumento de receita foram pouco notados pelas empresas, devido ao estágio em que se encontram as empresas em relação ao tema quanto também a maturidade do mercado consumidor, que ainda não reconhece esses investimentos.

O impacto mais percebido no item 'maior incorporação da sustentabilidade na gestão da empresa' pode realmente ter acontecido, mas analisando os três estudos realizados com as empresas participantes, percebe-se que a incorporação da sustentabilidade aconteceu de forma sutil, por meio de ações como coleta seletiva e utilização de material reciclado em sua maioria, com poucos impactos efetivos na gestão das empresas. 
Durante a reunião de encerramento do Programa Tear na cadeia de construção civil - incorporação (02 de outubro de 2008), foi realizada uma atividade de reflexão sobre as principais dificuldades encontradas pelas empresas. Seguem abaixo listadas as dificuldades consideradas mais relevantes:

- dificuldade de comprometimento da alta direção nas ações de responsabilidade social;

- ausência de exigências do Instituto Ethos e âncoras com relação aos resultados das empresas participantes;

- dificuldade de "vender" o tema, já que não é uma prioridade;

- falta de clareza nas metas a serem alcançadas;

- ausência de contrapartida quanto ao fortalecimento das relações entre empresa âncora e fornecedores;

- entendimento inicial equivocado de que as empresas âncora eram exemplos a serem seguidos;

- heterogeneidade das empresas participantes criou dificuldades para solução dos problemas do setor;

- excesso de ferramentas na metodologia atrapalhou sua aplicação.

Nota-se que a percepção das empresas participantes em relação ao Programa Tear se alinha com diversos aspectos levantados na análise apresentada no item 5.1. Questões como a falta de clareza nos objetivos e a ausência de cobrança efetiva em relação aos participantes podem ter comprometido os resultados finais do programa. Conforme divulgado no sítio da internet do Instituto Ethos (anexo 1), os indicadores consolidados do Programa Tear de todas as cadeias de valor apresentam resultados de impacto, porém poderiam ter sido melhores caso algumas correções tivessem sido feitas ao longo do programa. A evasão de algumas empresas, não só da cadeia de valor de construção civil incorporação como também nas demais, poderia ter sido evitada por meio de uma avaliação e análise mais aprofundada durante o programa.

Como encerramento desse item, segue abaixo uma análise da pesquisadora quanto aos objetivos iniciais do Instituto Ethos em relação ao Programa Tear frente ao 
acompanhamento do programa e aos estudos realizados nas empresas participantes.

- Maior incorporação da sustentabilidade em sua gestão: as empresas tiveram oportunidade de conhecer o tema e buscar formas de incorporá-lo a gestão, porém, considerando as ações realizadas pelas empresas, é possível afirmar que o tema encontra-se em evolução, e os impactos efetivos só poderão ser mensurados em longo prazo.

- Acesso a novos mercados e desenvolvimento de novos produtos e serviços: as evidências de acesso a novos mercados foram discretas. $O$ impacto que se percebeu foi em relação às iniciativas de algumas empresas participantes em se projetarem no mercado na divulgação do tema da responsabilidade social.

- Aprofundamento e melhoria das relações comerciais com os parceiros envolvidos: as relações comerciais com as empresas âncoras não foram explicitamente aprofundadas e melhoradas, uma vez que não era esse o objetivo do programa, mas pelo fato das empresas participantes atuarem em segmentos diversos, esse aspecto foi pouco explorado no decorrer do programa.

- Identificação de oportunidades de desenvolvimento de novos produtos e serviços: algumas empresas puderam se projetar no mercado com uso do tema, como os escritórios de arquitetura, que criaram diferenciais sustentáveis em seus produtos, destacando sua atuação. Porém esse não foi um fato ocorrido em todas as empresas.

- Redução de custos: não houve relatos de redução de custos pela participação no Programa Tear.

- Aumento de receita: ainda não foi identificado aumento de receita significativo pela participação no Programa Tear.

- Ganhos de competitividade e produtividade: ainda não foram identificados ganhos significativos de competitividade e produtividade pela participação no Programa Tear. 
- Documentação e multiplicação das melhores práticas: considerando o universo das empresas participantes de todas as cadeias, a documentação e multiplicação das melhores práticas podem ser consideradas baixas, uma vez que apenas 29 casos foram cadastrados no Banco de Práticas do Instituto Ethos, sendo apenas um caso de pequena empresa da cadeia de valor de construção civil - incorporação e um caso da empresa âncora Gafisa.

- Modelo e referência para o desenvolvimento do programa no seu segmento de atuação: o Programa Tear, com seus possíveis ajustes, certamente será um modelo de referência para a implantação da responsabilidade social em cadeias de valor, porém de difícil aplicação para as pequenas e médias empresas participantes.

- Visibilidade/projeção nacional e internacional: por ser um programa promovido pelo Banco Interamericano de Desenvolvimento, os resultados do Programa Tear terão repercussão e projeção internacional, cabe ao Instituto Ethos promover essa divulgação.

- Contribuição para o desenvolvimento local sustentável e para a sustentabilidade do país: a contribuição do programa para a sustentabilidade do país é difícil de ser mensurada, mas sem dúvida criou diversos multiplicadores que aos poucos irão ampliar a visão de outras empresas em relação à responsabilidade social.

\subsection{Diretrizes para empresas contratantes}

Na proposta inicial da pesquisa, imaginou-se que a contribuição do Programa Tear na elaboração de diretrizes para incorporadoras e construtoras trabalharem a questão da responsabilidade social com seus fornecedores seria maior. A idéia era conhecer as empresas fornecedoras de pequeno e médio porte e propor ações para incentivo à responsabilidade social que dessem resultado efetivo, conforme teria sido constatado no programa. Porém, como o perfil das empresas participantes do programa não retrata a realidade do setor e também possuem realidades bastante distintas, pouco se pode aprender da experiência nesse sentido. No entanto, para que essa pesquisa pudesse, ao menos em parte, atingir esse objetivo, optou-se por 
propor um conjunto de diretrizes para incorporadoras e construtoras tratarem a responsabilidade social junto aos seus fornecedores, baseada nos aprendizados adquiridos na revisão bibliográfica, na experiência do Programa Tear e nos estudos realizados, de forma a estimular a reflexão em relação ao tema considerando as características de cada empresa a ser trabalhada.

Esse conjunto de diretrizes proposto aplica-se a qualquer incorporadora ou construtora e busca auxiliar no investimento da responsabilidade social junto aos fornecedores, uma vez que na pesquisa apresentada sobre as ações de responsabilidade social desenvolvidas pelas empresas do setor da construção (tabela 1) não se destacou nenhuma iniciativa que atuasse diretamente em parceria com fornecedores.

Nesse sentido, diversas ações podem ser promovidas por incorporadoras e construtoras, porém é importante que essas ações sejam realizadas de forma planejada, que promovam a incorporação da sustentabilidade nas empresas fornecedoras, e que permitam uma mensuração posterior, possibilitando dessa forma a melhoria contínua das mesmas, e que considerem a realidade do negócio de cada empresa em particular.

O conjunto de diretrizes proposto a seguir, que parte do princípio da empresa incorporadora ou construtora ter interesse em investir em responsabilidade social e esteja engajada em atuar com seus fornecedores, desenvolve-se em oito etapas:

- diagnóstico inicial da responsabilidade social;

- alinhamento estratégico dos departamentos da empresa;

- escolha dos fornecedores;

- perfil dos fornecedores;

- plano de ação;

- organização do programa dentro da empresa;

- implementação;

- melhoria contínua. 


\subsubsection{Diagnóstico inicial da responsabilidade social}

Antes do início do investimento em responsabilidade social, é importante que as empresas realizem um diagnóstico inicial de sua gestão que possibilite a mensuração dos resultados após certo período. Para isso, pode ser utilizada a metodologia dos Indicadores Ethos de Responsabilidade Social já mencionados nessa dissertação, com a devida cautela na análise das prioridades a serem focadas.

Com um diagnóstico em mãos, a empresa poderá planejar seus investimentos de maneira mais direcionada, buscando dessa forma atingir os resultados esperados. Após a definição das prioridades a serem abordadas, deverão ser levantados os recursos necessários para as ações a serem realizadas. Nessa dissertação será tratada apenas a parte interessada fornecedor.

\subsubsection{Alinhamento estratégico dos departamentos da empresa}

Para investir em responsabilidade social com os fornecedores, é importante que todos os departamentos da empresa com os quais exista interface estejam alinhados para melhor direcionar as ações a serem promovidas. É recomendável que seja formada uma comissão interna, com representantes de cada área envolvida, para a capacitação da equipe, desenvolvimento e implementação das ações.

\subsubsection{Escolha dos fornecedores}

Como são muitos os fornecedores que fazem parte da cadeia de uma incorporadora ou construtora, não há como se trabalhar com todos. Assim, com a comissão formada, é necessário estabelecer um critério para escolha dos fornecedores a serem geridos com base nos conceitos da responsabilidade social. Um dos critérios que pode ser utilizado para essa escolha é a análise da curva $A B C$ do orçamento dos empreendimentos, ficando mais evidentes os fornecedores de maior impacto financeiro. Outra opção é escolher os fornecedores considerados estratégicos, pois seus fornecimentos são essenciais à sustentação da estratégia competitiva da empresa. Além do custo, expresso pela curva $A B C$, podem ser usados critérios como pertencerem ao caminho crítico, fornecerem conteúdo tecnológico de 
inovação, prestarem serviços de atendimento a critérios críticos de desempenho, etc.

Os fornecedores podem ainda ser divididos em duas categorias, materiais e serviços, e para cada uma delas também é possível elencar os de maior impacto financeiro ou papel estratégico. Outros critérios como incidência de fornecimento ao longo do empreendimento ou tipo de empresa (porte, número de funcionários) também podem utilizados. O importante nessa etapa é definir os critérios de escolha das empresas a serem abordadas, para somente então selecioná-las.

\subsubsection{Perfil dos fornecedores}

Com o critério de escolha dos fornecedores definido, é necessário conhecê-los de forma mais aprofundada. Para isso, é necessário elaborar um questionário que permita diagnosticar a situação de cada empresa fornecedora. Esse questionário deve levantar informações como tempo de fundação da empresa, número de funcionários, sistemas de gestão utilizados, ações de responsabilidade social existentes, bem como outras relacionadas à sustentação do papel estratégico a ela atribuído (custo, prazo, inovação, desempenho, etc.).

Além disso, o perfil dos fornecedores de materiais deve conter o tipo de material fornecido, seus impactos ao meio ambiente, suas possibilidades de reaproveitamento e sua disponibilidade no mercado (quantidade de fornecedores). Para os serviços prestados, deve ser analisado o tipo, por quanto tempo ele é realizado no empreendimento, quantos funcionários estão envolvidos, quais recursos são necessários e quais os impactos causados pela atividade.

\subsubsection{Plano de ação}

Com base nos perfis dos fornecedores, deve ser realizada uma reunião de brainstorming (ou tempestade de idéias) pela comissão de representantes das áreas envolvidas com os fornecedores para levantamento de possíveis ações a serem desenvolvidas com cada um deles. A comissão pode ainda optar por contratar uma consultoria externa para auxiliar na estruturação do plano de ação. 
É importante integrar os fornecedores ao processo de seleção das ações a serem desenvolvidas desde o início, de forma a conquistar o apoio e o comprometimento necessários para o sucesso da gestão socialmente responsável, e fazer com que o fornecedor incorpore as ações em sua empresa independentemente do vínculo comercial existente com a empresa promotora da iniciativa.

Com base na experiência do Programa Tear e das empresas fornecedoras participantes, diversas ações podem ser desenvolvidas e incentivadas pelas incorporadoras / construtoras:

- Incentivo a coleta seletiva;

- Exigências de uso de materiais sustentáveis;

- Promoção da capacitação profissional, incluindo a formação básica, como a alfabetização;

- Acompanhamento periódico do cumprimento das leis;

- Incentivo a promoção de melhores condições para os operários da construção civil;

- Capacitação das empresas em responsabilidade social;

- Doações;

- Desenvolvimento de materiais/tecnologias mais sustentáveis;

- Incentivo ao lazer e cultura.

\subsubsection{Organização do programa dentro da empresa}

Definidas as ações a serem desenvolvidas pelos fornecedores, as incorporadoras e construtoras devem se organizar internamente para o atendimento de todas as demandas que estes farão, uma vez que as incorporadoras e construtoras farão o papel de disseminadores da responsabilidade social.

Primeiramente, é importante listar os processos envolvidos nas ações a serem realizadas e os departamentos que neles intervêm (suprimentos, produção, jurídico, planejamento, etc.), para promover um treinamento de conscientização sobre os objetivos de investimento em responsabilidade social dos profissionais que neles 
atuam. Devem ser apresentadas as responsabilidades de cada área para que a gestão socialmente responsável dos fornecedores tenha sucesso, e as conseqüências positivas que trarão aos diferentes processos da empresa.

Os recursos necessários deverão ser listados para que seja possível um acompanhamento dos investimentos. Nesse caso, devem ser listados tanto recursos financeiros, como os recursos humanos, etc. Devem ser criados ainda indicadores que possibilitem o monitoramento das ações desenvolvidas, para avaliações futuras de sua eficácia.

Também deve ser prevista a divulgação das ações de responsabilidade social para que as demais partes interessadas tenham conhecimento da iniciativa da incorporadora/construtora.

\subsubsection{Implementação}

As empresas com as quais a incorporadora/construtora pretenda desenvolver ações de responsabilidade social deverão ser convidadas para uma apresentação do programa a ser desenvolvido, de forma a esclarecer os objetivos da iniciativa.

A incorporadora/construtora deverá incluir em seus contratos, ordens de compra e demais documentos de comunicação com os fornecedores todas as diretrizes para que se estimulem as ações de responsabilidade social a serem realizadas.

O efetivo desenvolvimento das ações deverá ser realizado de acordo com as premissas definidas anteriormente, de forma a promover a responsabilidade social junto aos fornecedores.

\subsubsection{Melhoria contínua}

Periodicamente, a incorporadora/construtora deverá promover uma análise crítica das ações desenvolvidas junto aos fornecedores para avaliar sua eficácia. Essa análise deve ser feita pela direção da empresa e também pela comissão que atua diretamente com os fornecedores, a fim de promover o aprimoramento e a evolução das ações, ampliando seu escopo de fornecedores e também o seu impacto. 


\section{CONCLUSÕES}

Nesse capítulo final, apresenta-se uma síntese da revisão bibliográfica e de toda a experiência do Programa Tear (com seus pontos positivos e negativos); os resultados da participação das empresas no programa; a conclusão das análises feitas no capítulo cinco, inclusive das diretrizes para incorporadoras e construtoras adotarem a responsabilidade social em sua gestão e finalmente as propostas para trabalhos futuros de pesquisa e desenvolvimento sobre o tema.

Quanto à bibliografia revisada, é possível concluir que o tema encontra-se bastante avançado em termos de definições e pesquisa. A questão da abrangência da responsabilidade social em relação ao meio ambiente ainda encontram-se sem consenso, uma vez que o termo responsabilidade sócio-ambiental é citado por diversos autores.

Ainda não existem evidências concretas que relacionem 0 investimento em responsabilidade social a um melhor desempenho financeiro, mas o que fica claro é que cada vez mais a ausência desse investimento poderá trazer conseqüências negativas para as empresas. Diante disso, a responsabilidade social, que atualmente ainda pode ser interpretada como um diferencial no mercado competitivo, aos poucos tende a se tornar uma premissa básica a fazer parte da gestão das empresas. Considerar os interesses e expectativas das partes interessadas para definição de estratégias de atuação poderá ser algo de extrema importância conforme o avanço e amadurecimento do tema.

Analisando os perfis dos fornecedores da construção civil e das incorporadoras e construtoras por meio da revisão bibliográfica e do acompanhamento do Programa Tear, percebe-se que não há ainda um movimento consolidado para solucionar os problemas referentes à responsabilidade social no setor. As ações desenvolvidas por algumas empresas do setor são pontuais e dispersas, e não caracterizam um amadurecimento do setor em reconhecer os impactos de suas atividades e promover ações para minimizá-los ou mesmo mitigá-los.

Considerando o primeiro objetivo da pesquisa, que é a análise e avaliação da implementação do Programa Tear, pode-se concluir que a participação da 
pesquisadora nas reuniões do grupo como observadora permitiu uma análise qualitativa da metodologia aplicada e dos resultados apresentados. Fundamentada na revisão bibliográfica e nos estudos de programas similares quanto à dinâmica utilizada, considera-se o Programa Tear uma iniciativa capaz de disseminar os conceitos de responsabilidade social de maneira introdutória, despertando às empresas participantes a importância do tema e as suas possibilidades de investimento. Porém, algumas constatações demonstram que o programa pode ser melhorado para novas edições, já que na primeira versão destacaram-se alguns pontos importantes que podem ter comprometido os resultados apresentados:

- em relação à forma de condução, os objetivos inicias e os resultados a serem alcançados precisavam ser mais evidentes, possibilitando ao Instituto Ethos uma condição favorável para cobrar de forma mais efetiva as atividades propostas para as empresas;

- em relação às ferramentas utilizadas, elas foram em alguns momentos pouco eficientes, e poderiam ser ajustadas para melhor auxiliar as empresas participantes, podendo ser mais claras e simples, buscando atender a diversidade de negócios envolvidos e as diversas realidades de tamanho das empresas;

- em relação à experiência em si, a metodologia aplicada em grupo mostrou-se bastante adequada, permitindo a troca de experiências entre os participantes, porém ficou prejudicada pela heterogeneidade das empresas.

Conjectura-se ainda se o Programa Tear, que teve o intuito de capacitar as pequenas e médias empresas de diversos setores da economia brasileira, não poderia obter maior sucesso caso tivesse sido implantando primeiramente nas grandes empresas de cada setor e também nas entidades de classe, que possuem grande potencial de disseminação de novas tendências. Tendo como ponto de partida as grandes empresas, a própria estrutura e relação comercial já existente com seus fornecedores de menor porte já seria um cenário favorável para a troca de experiências e a disseminação de práticas de responsabilidade social.

Ainda em relação ao Programa Tear, os objetivos iniciais propostos pelo programa não foram totalmente atingidos, ao menos no setor da construção civil, uma vez que 
as próprias empresas não conseguiram identificar em sua gestão as mudanças inicialmente esperadas. Esse diagnóstico demonstra o quanto a mudança de cultura e valores nas empresas é algo bastante complexo, que exige dedicação e tempo para que os efeitos possam ser percebidos em todo um setor ou mesmo na sociedade.

Não se tem informação sobre o resultado do programa nos demais setores onde foi implementado. Mas, de qualquer forma, uma questão importante a ser considerada é que as pequenas e médias empresas não possuem recursos suficientes para convencer ou mesmo incentivar seus clientes a investir em responsabilidade social. E se seus clientes não estão engajados no mesmo processo, todo o investimento pode resultar em algo que eles não reconheçam, não favorecendo a gestão socialmente responsável em longo prazo. Isso pode comprometer inclusive a metodologia do Programa Tear, que visa a continuidade da capacitação por meio das empresas participantes desse programa piloto.

Considerando os efeitos do Programa Tear nas empresas participantes, percebe-se que os impactos causados pelo movimento da responsabilidade social só poderão ser mensurados daqui a alguns anos. O Programa Tear pode ser caracterizado como uma ferramenta de fomento da responsabilidade social, e somente em longo prazo será possível avaliar se, a exemplo do movimento da gestão da qualidade, a gestão da responsabilidade social será realmente um fator associado à gestão integrada das empresas, focada nos processos associados às atividades de cada negócio.

Da mesma forma como no movimento da qualidade, onde a evolução dos métodos de gestão da qualidade requer uma maior integração, tanto vertical (diretrizes) quanto horizontal (processos e atividades) da empresa, (MARTINS, 1998), esse processo será necessário na gestão da responsabilidade social. Para sustentação das diretrizes da responsabilidade social, serão necessários procedimentos de como conduzir as atividades e processos da empresa, de forma a atender seus objetivos e também as demandas das partes interessadas, gerando assim um sistema integrado de gestão, que atenda às questões de qualidade, meio ambiente e segurança do trabalho. Dessa forma, os referenciais normativos se complementam ao Programa 
Tear, dando mais estrutura e resultado aos conceitos abordados ao longo do programa.

Com relação às diretrizes de inserção da responsabilidade social na gestão de incorporadoras e construtoras em relação a seus fornecedores, esperava-se se obter maiores subsídios na experiência do Programa Tear em relação aos tipos de ações que poderiam ser desenvolvidas junto à cadeia de fornecedores. O que ficou constatado é que a realidades das empresas participantes do Programa Tear é bastante distinta, não permitindo dessa forma a identificação de um padrão de comportamento que pudesse ser tratado similarmente em todas elas. Diante disso, percebe-se que não existe um formato padrão para inserção do tema, uma vez que independente da atividade desempenhada pela empresa, suas características sempre a diferenciarão das demais, cabendo ao indutor da ação, incorporadora ou construtora, identificar os potenciais de atuação conforme sugerido por meio das diretrizes propostas. Nesse sentido se justifica a proposta de diretrizes que permitam as empresas incorporadoras e construtoras um meio de identificar as características da empresa com a qual pretendem desenvolver ações de responsabilidade social.

\section{Sugestão para pesquisas futuras}

Sugere-se para pesquisas futuras a formação de um novo grupo, formado apenas por incorporadoras e construtoras, para uma nova edição do Programa Tear, onde inicialmente fossem levantados os principais problemas do setor referentes a responsabilidade social e toda a metodologia do programa poderia ser voltada para a solução desses problemas.

O detalhamento e implementação das diretrizes propostas nessa dissertação poderia ser realizado também em uma empresa incorporadora ou construtora para avaliação de seus efeitos e resultados, juntamente com a criação de indicadores para controle das ações junto a cadeia de fornecedores, permitindo avaliar seu impacto no setor. 


\section{REFERÊNCIAS BIBLIOGRÁFICAS}

ASSOCIAÇÃO BRASILEIRA DE NORMAS TÉCNICAS. NBR 16001: Responsabilidade social - sistema da gestão - requisitos. Rio de Janeiro, 2004. 11p. ACCOUNTABILITY. AccountAbility 1000 (AA 1000) - Framework. Standards, guidelines and professional qualification. London, 1999. 163p.

AccountAbility 1000 (AA 1000) - Estrutura. Norma, diretrizes e qualificação profissional. São Paulo, 2002. 112p.

. AccountAbility 1000 (AA 1000) Assurance Standard. London, 2003. 40p.

AccountAbility 1000 (AA 1000) - Stakeholder Engagement Standard. Framework, Standards, guidelines and professional qualification. London, 2005. 66p.

ASSOCIATION FRANÇAISE DE NORMALISATION. SD 21000 - Sustainable development - Corporate social responsibility. Guide for the taking into account of the sakes of sustainable development in the enterprise management and strategies. Saint-Denis La Plaine, 2003. 41p.

ASHLEY, P. (Coord.) Ética e responsabilidade social nos negócios. São Paulo. Saraiva, 2002.

BANCO INTERAMERICANO DE DESENVOLVIMENTO. Apresenta informações sobre o BID. Disponível em: <www.iadb.orb >. Acesso em: 06 set. 2007.

BLAKE, J. Caring for the bottom line. Human Resourse Planning, v. 30, n. 1, p. 36, 2007.

BLANCO, M. Planejar para não faltar. Guia da Construção Mercado - Revista Construção Mercado, n. 77, p. 11-13, 2007.

BOLSA DE VALORES DO ESTADO DE SÃO PAULO. Apresenta informações sobre Índice de Sustentabilidade Empresarial. Disponível em: <www.bovespa.com.br>. Acesso em: 14 out. 2007. 
BORGER, G. Responsabilidade social: efeitos da atuação social na dinâmica empresarial. 2001. 258p. Tese (Doutorado) - Faculdade de Economia, Administração e Contabilidade da Universidade de São Paulo. São Paulo, 2001.

BOWEN, H. R. Social responsibilities of the businessman. New York: Harper \& Row, 1953.

BRANCO, M. C.; RODRIGUES, L. L. Corporate social responsibility and resourcebased Perspectives. Journal of Business Ethics, n. 69, p. 111-132, 2006.

BSD Brasil. Apresenta informações sobre a BSD Brasil. Disponível em: < $\underline{w w w . b s d-}$ net.com>. Acesso em: 03 nov. 2007.

AA1000: Estrutura de gestão da responsabilidade corporativa. Disponível em: <www.bsd-net.com/bsd brasil/handbookaa1000.pdf>. Acesso em: 03 nov. 2007.

BT GLOBAL SERVICES. Apresenta informações sobre a empresa BT Global Services. Disponível em: <www.btglobalservices.com>. Acesso em: 17 nov. 2007.

CÂMARA BRASILEIRA DA INDÚSTRIA DA CONSTRUÇÃO (CBIC). Apresenta informações sobre o Prêmio CBIC de Responsabilidade Social. Disponível em: <www.cbic.og.br>. Acesso em: 20 nov. 2007 e em 22 set. 2008.

CARDOSO, F. F.; SILVA, F. B.; FABRICIO, M. M. Os fornecedores de serviços de engenharia e projetos e a competitividade das empresas de construção de edifícios. Brasil - São Paulo, SP. 1998. 7p. In: NUTAU, São Paulo, 1998.

CARROL, A. B. Corporate social responsibility. Business and Society, v. 38, n. 3, p. 268, 1999.

. Corporate social responsibility: Its managerial impact and implications, University of Georgia. Journal of Business Research, v. 2, n. 1, p. 75-88, 1974.

COMISSÃO DAS COMUNIDADES EUROPÉIAS. Livro Verde - Promover um quadro europeu para a responsabilidade social das empresas. Bruxelas, 2001. 
ENQUIST, B.; JOHNSON, M.; SKÅLÉN, P.. Adoption of corporate social responsibility - incorporating a stakeholder perspective Service Research Center. Sweden Qualitative Research in Accounting \& Management, v. 3, n. 3, p. 188$207,2006$.

FEDATO, M. C. L. Responsabilidade social corporativa: benefício social ou vantagem competitiva? 2005, 140p. Dissertação (Mestrado) - Faculdade de Economia, Administração e Contabilidade da Universidade de São Paulo. São Paulo, 2005.

FELDBERG, M. Defining social responsibility. Graduate School of Business, University of Cape Town, 1974.

FONTANINI, P. S. P.; PICCHI, F. A. Mentalidade enxuta na cadeia de fornecedores da construção civil - aplicação de macro-mapeamento. Simpósio Brasileiro de Gestão e Economia da Construção. São Carlos: III SIBRAGEC, 2003.

FREEMAN, E.; LIEDTKA, J. Stakeholder Capitalism and the Value Chain. European Management Journal, v. 15, n. 3, pp. 286-296, 1997.

FUNDAÇÃO VANZOLINI. Referencial Técnico de Certificação "Edifícios do Setor de Serviços - Processo AQUA". Escritórios e Edifícios escolares. Em cooperação com CERTIVÉA, Group CSTB. São Paulo, 2007. Adaptação para o Brasil: Versão 0 (provisória) 15/10/2007. 241p.

FURTADO, G. A. P. Critérios de seleção de fornecedores para relacionamentos de parceria: um estudo em empresas de grande porte. 2005, 131p. Dissertação (Mestrado) - Faculdade de Economia, Administração e Contabilidade da Universidade de São Paulo. São Paulo, 2005.

FURTADO, J. S. Gestão com responsabilidade socioambiental. Princípios, códigos de conduta e capacitação para responsabilidade socioambiental. São Paulo, 2003.

GALBREATH, J. Corporate social responsibility strategy: strategic options, global considerations. Corporate Governance, v. 6, n. 2, p. 175, 2006. 
GARRIGA, E.; MELÉ, D. Corporate Social Responsibility Theories: Mapping the Territory. Journal of Business Ethics, n. 53, p. 51-71, 2004.

GLOBAL REPORTING INICIATIVE - GRI. Diretrizes para Relatório de Sustentabilidade. São Paulo, 2006.

GUILHERME, K. C. J. Parcerias entre construtoras e fornecedores de materiais e componentes. 2007, 85 p. Monografia - Programa de MBA em Tecnologia e Gestão na Produção de Edifícios. São Paulo, 2007.

HAGUENAUER, L.; BAHIA, L. D.; CASTRO, P. F.; RIBEIRO, M. B. Evolução das Cadeias Produtivas Brasileiras na Década de 90. Instituto de Pesquisa Econômica Aplicada (IPEA), Brasília, n. 786, abril de 2001.

HERNANDES, C. A. M; CRUZ, C. S.; FALCÃO, S. D. Combinando o Balanced Scorecard com a gestão do conhecimento. Caderno de Pesquisas em Administração, São Paulo, v. 1. n. 12, 9p., 2000.

INSTITUTO ETHOS DE EMPRESAS E RESPONSABILIDADE SOCIAL. São Paulo. Apresenta informações gerais sobre responsabilidade social e as ações do instituto. Disponível em: <www.ethos.org.br>. Acesso em: 06 set. 2007.

Indicadores Ethos de Responsabilidade Social Empresarial. São Paulo:

ETHOS, 2007. Disponível em: <www.ethos.org.br>. Acesso em: 06 set. 2007.

Metodologia Tear de Trabalho em Cadeia de Valor. São Paulo: ETHOS, 2007. Disponível em: <www.ethos.org.br>. Acesso em: 18 mai. 2008.

. Critérios Essenciais de Responsabilidade Social Empresarial e seus Mecanismos de Indução no Brasil. São Paulo: ETHOS, 2006.

. Guia de Compatibilidade de Ferramentas. São Paulo: ETHOS, 2004.

INSTITUTO BRASILEIRO DE ANÁLISES SOCIAIS E ECONÔMICAS. São Paulo. Apresenta informações gerais sobre o balanço social lbase e as ações do instituto. Disponível em: <www.ibase.br>. Acesso em: 13 abr. 2008. 
INTERNACIONAL ORGANIZATION FOR STANDARDIZATION. Apresenta informações sobre a ISO 26000. Disponível em: <www.iso.org>. Acesso em: 18 nov. 2007.

ISATTO, E. L., FORMOSO, C. T. Método para formulação da política de fornecedores por parte de empresas de construção. Entac 2006 - A construção do futuro. XI Encontro Nacional de Tecnologia no Ambiente Construído. Florianópolis: ENTAC 2006, p. 2360-2370.

ITCNET. Apresenta informações sobre o ranking das construtoras brasileiras. Disponível em: <www.itc.etc.br>. Acesso em: 29 abr. 2008.

JOBIM, M. S. S.; JOBIM FILHO, H.; MACIEL, V. Integração das cadeias de suprimentos da indústria da construção civil com base na seleção de fornecedores. Entac 2002 - IX Encontro Nacional de Tecnologia do Ambiente Construído. Foz do Iguaçu: ENTAC 2002, p. 633-642.

KITAHARA, J. R.. Responsabilidade Social e desempenho financeiro das empresas: um estudo empírico utilizando o balanço social padrão IBASE. 2007. 178p. Dissertação (Mestrado) - Faculdade de Economia, Administração e Contabilidade da Universidade de São Paulo. São Paulo, 2007.

LÓPEZ, M. V.; GARCIA, A.; RODRIGUEZ, L. Sustainable Development and Corporate Performance: A Study Based on the Dow Jones Sustainability. Journal of Business Ethics, n. 75, p. 285-300, 2007.

MARTINS, M. G. A inovação tecnológica na produção de edifícios impulsionada pela indústria de materiais e componentes. 2004. 139p. Dissertação (Mestrado) Pós-graduação em Engenharia da Escola Politécnica da Universidade de São Paulo. São Paulo, 2004.

MEIRA, L. C. C.; QUINTELLA, R. H. Relacionamento Clientes-Fornecedores sob a ótica da qualidade: um estudo em construtoras baianas participantes do PBQPH/QUALIOP. I Conferência Latino-Americana de Construção Sustentável clacs'04, X Encontro Nacional de Tecnologia do Ambiente Construído entac'04. 18-21 julho de 2004, São Paulo. 
MILES, M. P.; MUNILLA, Linda S.; DARROCH, J. The Role of Strategic Conversations with Stakeholders in the Formation of Corporate Social Responsibility Strategy. Journal of Business Ethics, n. 69, p. 195-205, 2006.

NASI, J.; NASI, S.; PHILLIPS, N.; ZYGLIDOPOULOS, S. The evolution of corporate social responsiveness. Business and Society, v. 36, n. 3, pg. 296, 1997.

NEVILLE, B. A.; MENGUC, B. Stakeholder Multiplicity: Toward an Understanding of the Interactions between Stakeholders. Journal of Business Ethics, n. 66, p. 377391, 2006.

OLIVEIRA, O. J. Modelo de gestão para pequenas empresas de projeto de edifícios. 2005. 262p. Tese (Doutorado) - Escola Politécnica da Universidade de São Paulo. São Paulo, 2005.

OBJETIVOS DO MILÊNIO. Apresenta informações sobre as oito metas do milênio. Disponível em: <http://www.nospodemos.org.br/objetivos.htm>. Acesso em: 06 jul. 2008.

PINHEIRO MACHADO Filho, C. A. Responsabilidade Social Corporativa e a criação de valor para as organizações: um estudo multicasos. 2002. 204p. Tese (Doutorado) - Faculdade de Economia, Administração e Contabilidade da Universidade de São Paulo. São Paulo, 2002.

REIS, P. F.; MELHADO, S. B. A influência do atual relacionamento entre as empresas construtoras e seus fornecedores de materiais e componentes sobre a qualidade do processo construtivo. VII Encontro Nacional de Tecnologia do Ambiente Construído - Qualidade no Processo Construtivo. Florianópolis: ANTAC, 1998.

SHANKLIN, W. L. Corporate Social Responsibility: Another View. Journal of Business Research, v. 4, n. 1, p. 75-84, 1976.

SOCIAL ACCOUNTABILITY INTERNACIONAL. Apresenta informações sobre a norma SA 8000. Disponível em: <www.sa-intl.org>. Acesso em: 03 nov. 2007. 
SOLANO, R.; HEINECK, L. F. M. Curva ABC de fornecedores - uma ferramenta para a qualidade. Congresso Técnico-Científico de Engenharia Civil. Florianópolis, 1996, p. 228-238.

SOUZA, A. L. R.; TANIGUTI, E. K.; CARDOSO, F. F. Relações Fornecedores X Empresas: Obrigações e Deveres. Nutau, 1998.

STERZI, M. P.; ISATTO, E. L.; FORMOSO, C. T. Integração de fornecedores estratégicos ao sistema de gestão da produção de uma empresa construtora. Entac 2006 - a construção do futuro. XI Encontro Nacional de Tecnologia no Ambiente Construído. Florianópolis: Entac, 2006, p. $2646-2655$.

STEURER, R.; LANGER, M. E., KONRAD, A.; MARTINUZZI, A. Corporations, Stakeholders and Sustainable Development I: A Theoretical Exploration of BusinessSociety Relations. Journal of Business Ethics, n. 61, p. 263-281, 2005.

QUEIROZ, A. A responsabilidade social das empresas no Brasil: um estudo sobre indicadores. V Congreso Internacional del CLAD sobre la Reforma del Estado y de la Administración Pública. Santo Domingo: CLAD 2000, 14p.

THIAGO, E. S. Rumo à Norma Internacional de Responsabilidade Social - ISO 26000. Palestra apresentada em 22/11/06 no Ciclo de Seminários de Normalização em Responsabilidade Social, São Paulo.

United Nations. Report of the World Commission on Environment and Development: Our Common Future. Disponível em <http://www.undocuments.net/wced-ocf.htm>. Acesso em: 11 nov. 2007.

Agenda 21. Disponível em <http://www.un.org/esa/sustdev/documents/agenda21/english/agenda21 toc.htm>. Acesso em: 11 nov. 2007.

URSINI, T. R.; SEKIGUCHI, C. Desenvolvimento Sustentável e Responsabilidade Social: Rumo à Terceira Geração de Normas ISO. Inovação, legislação e inserção social, v. 4, coleção Uniemp Inovação, Instituto Uniemp, São Paulo, 2005. 
VIEIRA, R. F. A iniciativa privada no contexto social: Exercício de Cidadania e Responsabilidade Social Parte III: As Ações Corporativas nos Investimentos Sociais. RP em Revista, ano 5, n. 22, 2007.

WORLD BUSINESS COUNCIL FOR SUSTAINABLE DEVELOPMENT. Corporate Social Responsibility - Meeting changing expectation. 30p, 1999.

ZACHARIAS, O. SA 8000 - Responsabilidade Social - NBR 16000. Estratégia para Empresas Socialmente Responsáveis. São Paulo. Editora EPSE, 2004.

ZUTSHI, A.; SOHAL, A. A study of the environmental management system (EMS) adoption process within Australasian organizations - Role of stakeholders. Department of Management, Monash University, 2002. 


\section{APÊNDICES}

\section{Apêndice 1 - Questionário para indutores de iniciativas}

Implantação da responsabilidade social empresarial na gestão de fornecedores

\section{da construcão civil - Análise do Programa Tear}

Priscila de França Pinheiro - Março de 2008

\section{QUESTIONÁRIO PARA ENTREVISTA}

\section{Grupo: Indutores de iniciativas de capacitação em grupos de empresas}

\section{FOCO DO ESTUDO: ENTENDIMENTO DA DINÂMICA DAS INICIATIVAS DE CAPACITAÇÃO EM GRUPOS DE EMPRESAS}

O presente questionário tem o objetivo de subsidiar a pesquisa que está sendo realizada no programa de pós-graduação em Engenharia Civil (Área de Engenharia de Construção Civil e Urbana) na Escola Politécnica da USP, de autoria da Eng ${ }^{a}$ Priscila de França Pinheiro, intitulada "Implantação da responsabilidade social empresarial na gestão de fornecedores da construção civil - Análise do Programa Tear" com orientação do Prof. Dr. Francisco Ferreira Cardoso.

O questionário segue antecipadamente apenas para apresentação do escopo da entrevista, e para comodidade do entrevistado, todas as informações serão documentadas pelo próprio pesquisador na ocasião da entrevista, que tem previsão de duração de 1:30h.

O entrevistado tem a liberdade de, a qualquer momento, interromper a entrevista ou mesmo recusarse a responder as perguntas que considerar não pertinentes.

Todas as informações obtidas nessa pesquisa serão utilizadas para fins acadêmicos. Caso seja sua determinação, sua identidade será mantida em sigilo. O produto final dessa pesquisa the será disponibilizado posteriormente.

\section{DATA DA ENTREVISTA:}

\section{LOCAL:}

1 Dados do entrevistado - Coordenador do grupo
$1.1 \quad$ Nome
1.2 Dados para contato (telefone e e-mail) 


\subsection{Profissão}

\section{Perguntas}

2.1 Qual o nome da iniciativa da qual participou? Qual era o objetivo? Há algum documento da iniciativa?

2.2 Quando ele foi implementado?

2.3 Quem a promoveu?

2.4 Qual era o seu papel na iniciativa setorial?

2.5 Qual foi o critério para aceitação das empresas na participação dessa iniciativa? Havia um perfil definido?

2.6 Quais eram os compromissos das empresas participantes com o programa?

2.7 Qual foi a duração do programa?

2.8 Como era a dinâmica do grupo (número de encontros, duração dos mesmos, conteúdo ministrado nos encontros)? O que achou dessa dinâmica?

2.9 Existia algum indicador para medir os resultados alcançados pelas empresas?

2.10 Quais foram os principais resultados alcançados?

2.11 O programa se repetiu? Quantas vezes? Em que ano? O que mudou?

2.12 Como o fato do grupo ser formado por concorrentes pesa nos resultados obtidos? Potencializa os resultados?

2.13 Qual abordagem você acredita ser eficaz no engajamento de empresas para investirem em iniciativas setoriais?

2.14 O modelo utilizado para essa iniciativa poderia ser replicado para abordagem de outros temas, como o da responsabilidade social, por exemplo?

2.15 Qual sua opinião sobre o tema Responsabilidade social na construção civil? 


\title{
Apêndice 2 - Questionário para entrevista com Instituto Ethos
}

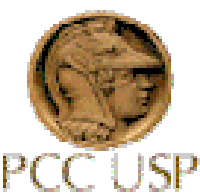 \\ Implantacão da responsabilidade social empresarial na gestão de fornecedores \\ da construção civil - Análise do Programa Tear \\ Priscila de França Pinheiro - Março de 2008 \\ QUESTIONÁRIO PARA ENTREVISTA \\ Grupo: Instituto Ethos - Indutor do Programa Tear
}

FOCO DO ESTUDO: ENTENDIMENTO DA ORIGEM DO PROGRAMA TEAR

O presente questionário tem o objetivo de subsidiar a pesquisa que está sendo realizada no programa de pós-graduação em Engenharia Civil (Área de Engenharia de Construção Civil e Urbana) na Escola Politécnica da USP, de autoria da Eng ${ }^{a}$ Priscila de França Pinheiro, intitulada "Implantação da responsabilidade social empresarial na gestão de fornecedores da construção civil - Análise do Programa Tear" com orientação do Prof. Dr. Francisco Ferreira Cardoso.

O questionário segue antecipadamente apenas para apresentação do escopo da entrevista, e para comodidade do entrevistado, todas as informações serão documentadas pelo próprio pesquisador na ocasião da entrevista, que tem previsão de duração de 1:30h.

O entrevistado tem a liberdade de, a qualquer momento, interromper a entrevista ou mesmo recusarse a responder as perguntas que considerar não pertinentes.

Todas as informações obtidas nessa pesquisa serão utilizadas para fins acadêmicos. Caso seja sua determinação, sua identidade será mantida em sigilo. O produto final dessa pesquisa lhe será disponibilizado posteriormente.

\section{DATA DA ENTREVISTA:}

LOCAL:

1 Dados do entrevistado - Representante do Instituto Ethos

1.1 Nome

1.2 Dados para contato (telefone e e-mail)

1.3 Profissão

2 Perguntas

2.1 De onde surgiu a idéia da criação do Programa Tear? 
2.2 Alguma iniciativa semelhante foi utilizada como inspiração?

2.3 Como foi o processo de formatação do Programa? (tempo de duração, busca por parceiros patrocínio)

2.4 Havia algum pré-requisito para atuar com PMEs?

2.5 Atuar com empresas de porte maior não faria com que o conceito de RS fosse mais disseminado nas cadeias, em função das PMEs terem menos influência nas demais?

2.6 Como foi o processo de escolha das cadeias?

2.7 Como foi o processo e os critérios de escolha das empresas âncoras? Qual era o objetivo?

2.8 Qual foi a abordagem para convidá-las a participar do grupo?

2.9 Quais compromissos as empresas âncoras precisaram assumir para participar do programa? Vêm sendo cumpridos?

2.10 Qual foi o critério para as âncoras escolherem as PMEs?

2.11 O objetivo na escolha das PMEs era ter representado todos os agentes de cada cadeia?

\section{EM RELAÇÃO À DINÂMICA DO PROGRAMA}

2.12 Por que foi escolhido esse modelo? Houve alguma inspiração?

2.13 A dinâmica tem funcionado?

2.14 Qual o papel dos representantes do Ethos nas reuniões?

2.15 Os resultados têm sido medidos? Como? Os objetivos têm sido alcançados?

2.16 O programa, após essa primeira edição, será replicado para outras cadeias? Com alguma mudança?

2.17 No caso da cadeia Takaoka/Gafisa, as PMEs são bastante heterogêneas. Em outras cadeias, há uma maior homogeneidade na atividade das empresas? A troca de experiências é potencializada nesse caso?

2.18 O Ethos possui outras dinâmicas/ações com PMEs sobre responsabilidade social? 


\section{Apêndice 3 - Questionário para entrevista com empresa âncora}

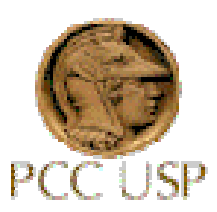

Implantação da responsabilidade social empresarial na gestão de fornecedores da construção civil - Análise do Programa Tear

Priscila de França Pinheiro - Março de 2008

QUESTIONÁRIO PARA ENTREVISTA

Grupo: Y. Takaoka - Âncora do Programa Tear

FOCO DO ESTUDO: ENTENDIMENTO DA PARTICIPAÇÃO DA EMPRESA NO PROGRAMA TEAR, IDENTIFICAÇÃO DE PRÁTICAS DE RESPONSABILIDADE SOCIAL E LEVANTAMENTO DE DEMANDAS PARA AÇÕES DE INCORPORADORAS/CONSTRUTORAS JUNTO A SUA CADEIA DE FORNECEDORES

O presente questionário tem o objetivo de subsidiar a pesquisa que está sendo realizada no programa de pós-graduação em Engenharia Civil (Área de Engenharia de Construção Civil e Urbana) na Escola Politécnica da USP, de autoria da Eng ${ }^{a}$ Priscila de França Pinheiro, intitulada "Implantação da responsabilidade social empresarial na gestão de fornecedores da construção civil - Análise do Programa Tear" com orientação do Prof. Dr. Francisco Ferreira Cardoso.

O questionário segue antecipadamente apenas para apresentação do escopo da entrevista, e para comodidade do entrevistado, todas as informações serão documentadas pelo próprio pesquisador na ocasião da entrevista, que tem previsão de duração de 1:30h.

O entrevistado tem a liberdade de, a qualquer momento, interromper a entrevista ou mesmo recusarse a responder as perguntas que considerar não pertinentes.

Todas as informações obtidas nessa pesquisa serão utilizadas para fins acadêmicos. Caso seja sua determinação, sua identidade será mantida em sigilo. O produto final dessa pesquisa lhe será disponibilizado posteriormente.

\section{DATA DA ENTREVISTA:} LOCAL:

1 Identificação da empresa

1.1 Razão social

1.2 Endereço 


\section{Dados do entrevistado}
2.1 Nome
2.2 Dados para contato (telefone e e-mail)
2.3 Cargo
2.4 Tempo de empresa

\section{Perfil da empresa}

3.1 Atividade principal

3.2 Número de funcionários (CLT e terceirizados)

3.3 Organograma

3.4 Principais nichos de atuação

3.5 Segmentos nos quais ainda não atua e pretende atuar no futuro

3.6 Modalidades de prestação de serviços

3.7 Sistemas de gestão utilizados

\section{Responsabilidade social}

4.1 Quando a Takaoka iniciou suas iniciativas de RS?

4.2 Qual grau de envolvimento da empresa com o tema?

4.3 Existe um controle financeiro dos investimentos destinados às ações de RS?

4.4 Quais os benefícios de investir em RS?

- Imagem?

- Relacionamento com clientes?

- Relacionamento com funcionários?

- Relacionamento com fornecedores?

- Outros?

4.5 Quais os aspectos que julga mais importantes nas ações de RS/Sustentabilidade?

4.6 Como vê a atuação das empresas concorrentes em relação à RS?

4.7 Quais foram os critérios para escolha das ações de RS desenvolvidas ao longo do Programa Tear?

4.8 Existe divulgação das ações de RS promovidas pela empresa?

4.9 Quem é responsável na empresa pelas ações de RS?

4.10 Quais os principais benefícios trazidos pela implantação das ações de RS até o momento?

4.11 Como as ações de RS estão relacionadas com os resultados da empresa? (imagem, inserção no mercado, vantagem competitiva, diferencial da marca)

4.12 Qual abordagem você acredita ser eficaz no engajamento de empresas para investirem em RS?

\section{Programa Tear}

5.1 Como foi o convite para a participação do Programa Tear?

5.2 Quais foram os principais fatores que levaram a empresa a participar do Programa Tear? 
5.3 Qual foi o critério para convite das PMEs participantes do Programa Tear? E como foi a parceria com a Gafisa no Programa Tear?

5.4 O que achou da dinâmica do programa?

5.5 Qual foi a dedicação necessária por parte da Takaoka?

5.6 Quais os principais benefícios trazidos pela participação da Takaoka no Programa Tear?

\section{Relacionamento com fornecedores}

6.1 Qual o seu critério de seleção de fornecedores?

6.2 Qual a justificativa para esse tipo de seleção?

6.3 O Programa Tear mudou seus critérios?

6.4 Existem exigências relacionadas à RS?

6.5 Quais exigências você pretende ou poderia implantar junto aos seus fornecedores em função da experiência no Programa Tear?

\section{Relacionamento com clientes}

7.1 Os clientes da Takaoka fazem alguma exigência específica de RS?

7.2 Você acredita de alguma forma poder influenciar seu cliente a adotar ações de RS de modo a valorizar o diferencial que sua empresa tem?

7.3 Você como incorporadoras/construtoras, o que sugere para melhoria das ações de RS dessas empresas em relação aos fornecedores delas? O que é possível, o que é urgente?

7.4 Que tipo de ações que incorporadoras/construtoras como a Takaoka poderiam desenvolver, porém você não acredita ser possível atualmente?

7.5 Analisando o mercado da construção civil de forma geral, quais demandas você acredita serem mais urgentes para consolidação da RS na atuação das empresas incorporadoras/construtoras? 


\title{
Apêndice 4 - Questionário para entrevista com participantes do Programa Tear
}

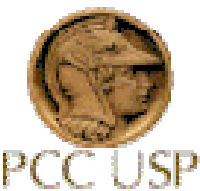

Implantacão da responsabilidade social empresarial na gestão de fornecedores da construção civil - Análise do Programa Tear

Priscila de França Pinheiro - Março de 2008
\end{abstract}

QUESTIONÁRIO PARA ENTREVISTA

Grupo: Empresas participantes do Programa Tear

\author{
FOCO DO ESTUDO: LEVANTAMENTO DE DEMANDAS PARA AÇÕES DE \\ INCORPORADORAS/CONSTRUTORAS JUNTO A SUA CADEIA DE FORNECEDORES
}

O presente questionário tem o objetivo de subsidiar a pesquisa que está sendo realizada no programa de pós-graduação em Engenharia Civil (Área de Engenharia de Construção Civil e Urbana) na Escola Politécnica da USP, de autoria da Eng ${ }^{a}$ Priscila de França Pinheiro, intitulada "Implantação da responsabilidade social empresarial na gestão de fornecedores da construção civil - Análise do Programa Tear" com orientação do Prof. Dr. Francisco Ferreira Cardoso.

O questionário segue antecipadamente apenas para apresentação do escopo da entrevista, e para comodidade do entrevistado, todas as informações serão documentadas pelo próprio pesquisador na ocasião da entrevista, que tem previsão de duração de 1:30h.

O entrevistado tem a liberdade de, a qualquer momento, interromper a entrevista ou mesmo recusarse a responder as perguntas que considerar não pertinentes.

Todas as informações obtidas nessa pesquisa serão utilizadas para fins acadêmicos. Caso seja sua determinação, sua identidade será mantida em sigilo. O produto final dessa pesquisa lhe será disponibilizado posteriormente.

\section{DATA DA ENTREVISTA:}

LOCAL:

\section{Identificação da empresa}

2.19 Razão social

2.20 Endereço 


\section{Dados do entrevistado da empresa responsável pelo preenchimento do questionário}

3.1 Nome

3.2 Dados para contato (telefone e e-mail)

3.3 Cargo

3.4 Tempo de empresa

\section{Perfil da empresa}

4.1 Atividade principal

4.2 Número de funcionários (CLT e terceirizados)

4.3 Organograma

4.4 Principais nichos de atuação

4.5 Segmentos nos quais ainda não atua e pretende atuar no futuro

4.6 Modalidades de prestação de serviços

4.7 Sistemas de gestão utilizados

\section{Responsabilidade social}

5.1 Já conhecia o tema Responsabilidade Social/Sustentabilidade?

5.2 Quais os aspectos que julga mais importantes nas ações de RS/Sustentabilidade?

5.3 Como vê a atuação das empresas concorrentes em relação à RS?

\section{Programa Tear}

6.1 O que o levou a participar do Programa Tear?

6.2 O que achou da dinâmica do programa? Quais os principais benefícios trazidos pela participação no Programa Tear?

6.3 Qual a dedicação necessária?

6.4 Tem dado resultado?

6.5 Qual grau de envolvimento da empresa com o tema?

6.6 Quais foram os critérios para escolha das ações de RS desenvolvidas ao longo do Programa Tear?

6.7 Existe um controle financeiro dos investimentos destinados às ações de RS?

6.8 Quais os benefícios de investir em RS?

- Imagem?

- Relacionamento com clientes?

- Relacionamento com funcionários?

- Relacionamento com fornecedores?

- Outros?

6.9 Existe divulgação das ações de RS promovidas pela empresa?

6.10 Quem é responsável na empresa pelas ações de RS?

6.11 Quais os principais benefícios trazidos pela implantação das ações de RS até o momento? 
6.12 Como as ações de RS estão relacionadas com os resultados da empresa? (imagem, inserção no mercado, vantagem competitiva, diferencial da marca)

6.13 Qual abordagem você acredita ser eficaz no engajamento de empresas para investirem em RS?

\section{Relacionamento com fornecedores}

7.1 Qual o seu critério de seleção de fornecedores?

7.2 Qual a justificativa para esse tipo de seleção?

7.3 O Programa Tear mudou seus critérios?

7.4 Existem exigências relacionadas à RS?

7.5 Quais exigências você pretende ou poderia implantar junto aos seus fornecedores em função da experiência no Programa Tear?

\section{Relacionamento com clientes}

8.1 As incorporadoras/construtoras fazem alguma exigência específica de RS para prestação de serviços? Se fazem, qual o grau de dificuldade para o atendimento das mesmas?

8.2 Você acredita de alguma forma poder influenciar seu cliente a adotar ações de RS de modo a valorizar o diferencial que sua empresa agora tem (ou pretende implantar)?

8.3 Você como fornecedor de incorporadoras/construtoras, o que sugere para melhoria das ações de RS dessas empresas em relação aos fornecedores delas? O que é possível, o que é urgente?

8.4 Que tipo de ações que incorporadoras/construtoras poderiam desenvolver, porém você não acredita ser possível atualmente?

8.5 Analisando o mercado da construção civil de forma geral, quais demandas você acredita serem mais urgentes para consolidação da RS na atuação das empresas incorporadoras/construtoras? 


\section{Apêndice 5 - Pesquisa com participantes do Programa Tear}

\section{PESQUISA - PROGRAMA TEAR - 16/06/2008}

\begin{tabular}{|c|c|c|c|c|c|}
\hline \multicolumn{6}{|c|}{ PESQUISA - PROGRAMA TEAR - 16/06/2008 } \\
\hline$\frac{(\mathrm{C}-\mathrm{J})}{\mathrm{PCC} U \mathrm{SP}}$ & \multicolumn{5}{|c|}{ 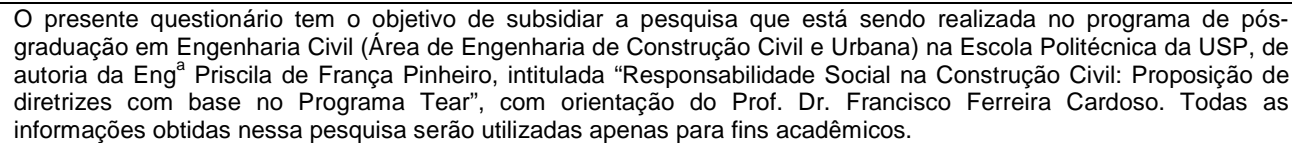 } \\
\hline \multicolumn{6}{|c|}{$\begin{array}{l}\text { Assinale com um X a alternativa que mais se aproximar da realidade de sua empresa ao participar do Programa } \\
\text { Tear, sendo: } \\
0 \text { para "não aconteceu" } \\
4 \text { para "aconteceu de forma discreta" - resultados pouco tangíveis } \\
7 \text { para "aconteceu de forma mediana" - resultados parcialmente tangíveis } \\
10 \text { para "aconteceu de forma efetiva" - resultados totalmente tangíveis }\end{array}$} \\
\hline & & 0 & 4 & 7 & 10 \\
\hline \multicolumn{6}{|c|}{ Maior incorporação da sustentabilidade na gestão da empresa } \\
\hline \multicolumn{6}{|c|}{ Acesso a novos mercados e desenvolvimento de novos produtos e serviços } \\
\hline \multicolumn{6}{|c|}{ Aprofundamento e melhoria das relações comerciais com os parceiros envolvidos } \\
\hline \multicolumn{6}{|c|}{ Identificação de oportunidades de desenvolvimento de novos produtos e serviços } \\
\hline \multicolumn{6}{|c|}{ Redução de custos operacionais da empresa } \\
\hline \multicolumn{6}{|c|}{ Aumento de receita } \\
\hline \multicolumn{2}{|c|}{ Ganhos de competitividade e produtividade } & & & & \\
\hline \multicolumn{2}{|c|}{ Empresa (opcional): } & & & & \\
\hline
\end{tabular}




\title{
ANEXOS
}

\section{RESULTADOS DO PROGRAMA TEAR}

\author{
(Disponível em <www.ethos.org.br> - Acesso em: 05 out. 2008).
}

\author{
Resultados gerais do Programa
}

Números atualizados em 29/09/2008

\section{Resultados gerais do Programa}

- Quantidade total de encontros: 183 GTs de 192 previstos no total das 8 cadeias

- Quantidade total de consultoria individual às PMEs: 5.367 horas de 6.912 horas previstas no total

- Imprensa: O projeto já foi notícia em jornais como: Folha de S. Paulo, O Estado de São Paulo, O Globo, Gazeta Mercantil; em revistas como: Visão Social e Grandes Compradores e Pequenos Fornecedores - Sebrae e na rádio CBN e site Invertia - Terra.

- Publicações lançadas: Responsabilidade Social Empresarial nos Processos Gerenciais e nas Cadeias de Valor, Critérios Essenciais de Responsabilidade Social Empresarial e seus Mecanismos de Indução no Brasil, Metodologia Tear de Trabalho em Cadeia de Valor e Pesquisa Nacional sobre práticas de RSE

- Seminários Regionais: já foram realizados 4 dos 4 seminários programados

10 Seminário: realizado em 26/abril/2007 em Belo Horizonte/MG organizado pelas âncoras ArcelorMittal Brasil e Vale

20 Seminário: realizado em 27/novembro/2007 no Rio de Janeiro/RJ organizado pelas âncoras Camargo Corrêa e Petrobras

$3^{\circ}$ Seminário: realizado em 24/abril/2008 em São Paulo/SP organizado pelas âncoras Gafisa, Grupo Pão de Açúcar e Y. Takaoka Empreendimentos

$4^{\circ}$ Seminário: realizado em 10/09/2008 organizado pelas âncoras CPFL Energia e Santelisa Vale Bioenergia

- Conferência Internacional do Ethos: $1^{a}$ oficina realizada na CI2007 e a $2^{a}$ oficina na CI2008

- Pessoas sensibilizadas: 1967 pela equipe do Programa e 23.734 pelas PMEs participantes (total $=25.701$ )

- Empresas participantes do programa: 97 PMEs

- Âncoras do programa: 9 grandes empresas - ArcelorMittal Brasil, Camargo Corrêa, CPFL Energia, Gafisa, Grupo Pão de Açúcar, Petrobras, Santelisa Vale Bioenergia, Vale e Y. Takaoka Empreendimentos

- Parceiros do programa: 8 parceiros - ABRADEE, ABRAPP, FIEMG, FIRJAN, IBRAM, IBP, Sebrae e ÚNICA

- Consultores capacitados: 48 em parceria com o Fórum Empresa - 6 atuam no programa

- Reuniões com as empresas-âncoras: já foram realizadas 9 das 9 reuniões programadas

- Reuniões com os consultores: já foram realizadas 8 das 8 reuniões programadas

- Indicadores Ethos aplicados: No $1^{\circ}$ ano por 9 grandes empresas e 84 PMEs; e no $2^{\circ}$ ano por 9 grandes empresas e 62 PMEs

- Relatórios Anuais de PMEs: 72 relatórios divulgados

Resultados alcançados pelas PMEs

Base de empresas no 10ano: 108

Base de empresas no 20 ano: 83

Maior incorporação da sustentabilidade na gestão

- $100 \%$ das PMEs com Missão e Visão elaboradas, buscando incorporar tema da sustentabilidade

- No $1^{\circ}$ ano, 84 PMEs aplicaram os Indicadores Ethos Geral ou Sebrae. No $2^{\circ}$ ano, 62 PMEs o fizeram

- $10 \%$ das PMEs implementaram o seu Código de Conduta no $1^{\circ}$ ano. Este número aumentou para $63 \%$ no $2^{\circ}$ ano

- 29 casos inseridos no Banco de Práticas do Ethos que relatam práticas de RSE realizadas a partir do programa (governança, público interno, meio ambiente, fornecedor, cliente, comunidade)

- No 10 ano $50 \%$ das PMEs haviam elaborado seu relatório socioambiental. No $2^{\circ}$ ano, $87 \%$ das PMEs elaboraram seu relatório socioambiental

Aprofundamento das relações comerciais com os parceiros envolvidos

- 4 grupos já alinharam, durante os encontros do Tear, demandas específicas pertinentes ao relacionamento na cadeia de valor (âncora-PMEs)

- 95\% das PMEs estão satisfeitas com as relações comerciais mantidas com a empresa âncora

- $66 \%$ das PMEs afirmam que as medidas de RSE implementadas contribuíram para melhorar suas relações comerciais com as grandes empresas

- Após os primeiros encontros os concorrentes se tornam parceiros na construção de uma nova forma de fazer negócio 
Acesso a novos mercados e desenvolvimento de novos produtos e serviços

- Através da análise dos seus pontos fortes e fracos e mapeamento de partes interessadas algumas PMEs já elaboraram estratégias, implementaram e obtiveram resultados positivos

- equilíbrio entre faturamento $x$ cliente

- incorporação de aspectos socioambientais no processo de desenvolvimento do seu produto final ou prestação de serviço

- identificação de agregação de valor no seu produto/serviço atual

\section{Ganhos de competitividade e produtividade}

- 130 novos clientes e 57 novos fornecedores incluídos nas relações comerciais viabilizados devido a participação no Programa Tear

- $71 \%$ afirmam que melhoraram as relações comerciais com as suas cadeias de valor

- Benefícios percebidos pelas empresas com o aprimoramento das relações com sua cadeia de valor:

\begin{tabular}{|l|l|l} 
& $\begin{array}{l}\text { No de } \\
\text { empresas }\end{array}$ & $\%$ \\
\hline Melhor diálogo ou resolução de conflitos & 55 & $66 \%$ \\
\hline Melhores negociações de venda & 31 & $37 \%$ \\
\hline Maior compromisso com prazos & 24 & $29 \%$ \\
\hline Maior compromisso com qualidade & 40 & $48 \%$ \\
\hline Ampliação do volume de negócios & 26 & $31 \%$ \\
\hline Diminuição dos riscos e problemas & 43 & $52 \%$
\end{tabular}

- A percepção das empresas sobre o impacto do Tear em seus indicadores econômicos é a seguinte:

\begin{tabular}{|c|c|c|c|}
\hline & $\begin{array}{l}\text { No de respostas } \\
\text { afimativas }\end{array}$ & $\%$ & \\
\hline $\begin{array}{l}\text { A implementaçào de açōes decorrentes da } \\
\text { participação no programa Tear trouxe reduçáo de } \\
\text { custos para as empresas }\end{array}$ & 22 & $27 \%$ & \multirow{2}{*}{ ֻ } \\
\hline $\begin{array}{l}\text { A implementaça de de açóes decorrentes da } \\
\text { participaçào no programa Tear trouxe aumento } \\
\text { de receita para as empresas }\end{array}$ & 25 & $30 \%$ & \\
\hline $\begin{array}{l}\text { Houve redução de custos na empresa ocasionado } \\
\text { por fatores externos a seu negocio }\end{array}$ & 9 & $11 \%$ & \\
\hline $\begin{array}{l}\text { Houve aumento de receita na empresa ocasionadas } \\
\text { por fatores externos a seu negócio }\end{array}$ & 33 & $40 \%$ & \\
\hline $\begin{array}{l}\text { Acreditam que a implementaçáo de açoes } \\
\text { decorrentes da participaçăano programa Tear trará } \\
\text { reduçáo de custos para a empresa }\end{array}$ & 60 & $72 \%$ & \multirow{2}{*}{ 을 } \\
\hline $\begin{array}{l}\text { Acreditam que a implementaçăo de açóes } \\
\text { decorrentes da participaçàono programa Tear trará } \\
\text { aumento de receita para a empresa }\end{array}$ & 68 & $82 \%$ & \\
\hline
\end{tabular}

\section{Benefícios para as empresas-âncoras}

- Potencialização dos resultados e sinergias entre o Programa Tear com a estratégia e gestão de outros programas da organização

- Compartilhamento de experiências, lições aprendidas e dilemas com as outras âncoras integrantes do Programa Tear

- Sensibilização, engajamento e comprometimento do seu público interno nos eventos (24 encontros e nos 4 seminários regionais) através:

da apresentação de suas práticas

da participação ativa nos encontros

da elaboração, compartilhamento e validação de seus planos de ação

- Acompanhamento dos Indicadores Ethos na gestão da sua cadeia de valor

- Diálogo com as empresas da sua cadeia de valor em um ambiente seguro e voltado para o aprendizado coletivo:

maior integração e fortalecimento da relação

mais discussões técnicas

melhoria na qualidade dos serviços

sugestões sobre processo de suprimento 